The Geological Society of America

Special Paper 534

\title{
Facies architecture, detrital provenance, and tectonic modulation of sedimentation in the Shikoku Basin: Inputs to the Nankai Trough subduction zone
}

\author{
Michael B. Underwood* \\ Department of Earth and Environmental Science, New Mexico Institute of Mining and Technology, \\ Socorro, New Mexico 87801, USA \\ Kevin T. Pickering* \\ Department of Earth Sciences, University College London, Gower Street, London, WC1E 6BT, UK
}

\begin{abstract}
The Shikoku Basin is a back-arc basin located offshore southwest Japan. Sediments within the basin make up a key part of the subduction inputs to the Nankai Trough. A 19 m.y. history of sedimentation has been documented at Sites C0011 and C0012 of the Integrated Ocean Drilling Program (Kumano transect) and Sites 1173 and 1177 of the Ocean Drilling Program (Muroto and Ashizuri transects, respectively). This paper focuses on three noteworthy aspects of that history: (1) the onset of substantial pyroclastic influx, which shifted significantly along the strike length of the margin, from 3.3-3.9 Ma at Sites 1177 and 1173 to 7.6-7.8 Ma at Sites C0011 and C0012; (2) transport of sand by sediment gravity flows, which resulted in three discrete sand bodies during the Miocene (Kyushu, Daiichi Zenisu, and Daini Zenisu submarine fans); and (3) clay mineral assemblages within hemipelagic mudstones, which show systematic reduction of $3 \mathrm{wt} \%$ detrital smectite per $1 \mathrm{~m} . y$. decrease in age. Collectively, these temporal and spatial adjustments of lithofacies and sediment composition have important implications for downdip and along-strike projections of frictional, geotechnical, and hydrogeological properties as strata enter the Nankai subduction zone. The stratigraphic positions of smectite-rich Miocene mudstones, for example, should match up with increases in the volume of fluid production by clay dehydration during subduction. The higher-permeability sand bodies (Kyushu and Zenisu submarine fans) should act as preferred conduits for focused fluid flow. The potential for buildup of fluid overpressures should increase above and laterally adjacent to stratigraphic pinchouts of sand bodies, especially where the aquifers are inclined or confined between basement highs. These three-dimensional complexities set the Nankai-Shikoku system apart from other subduction zones (e.g., Japan Trench, Costa Rica) where inputs consist of comparatively homogeneous pelagic and hemipelagic deposits.
\end{abstract}

*E-mails: UnderwoodM@missouri.edu; ktpickering@ucl.ac.uk.

Underwood, M.B., and Pickering, K.T., 2018, Facies architecture, detrital provenance, and tectonic modulation of sedimentation in the Shikoku Basin: Inputs to the Nankai Trough subduction zone, in Byrne, T., Fisher, D., McNeill, L., Saffer, D., Ujiie, K., Underwood, M., and Yamaguchi, A., eds., Geology and Tectonics of Subduction Zones: A Tribute to Gaku Kimura: Geological Society of America Special Paper 534, p. 1-XXX, https://dx.doi.org/10.1130/2018.2534(XX). 


\section{INTRODUCTION}

The Nankai Trough subduction zone is located offshore southwest Japan at the boundary between the Philippine Sea and Eurasia plates (Fig. 1). The overarching goal of the Nankai Trough Seismogenic Zone Experiment (NanTroSEIZE) has been to create a distributed array of boreholes along the subduction zone, extending across the updip limit of seismogenic and tsunamigenic behavior (Tobin and Kinoshita, 2006). All first-order elements of the plate boundary's architecture have been targeted by the Integrated Ocean Drilling Program (IODP), starting with the presubduction inputs of sediment and oceanic basement, moving landward across the frontal accretionary prism, and finally to depths beneath the forearc basin, where earthquakes occur (Ashi et al., 2009; Screaton et al., 2009a Tobin et al., 2009; Expedition 319 Scientists, 2010; Underwood et al., 2010; Expedition 333 Scientists, 2012a; Strasser et al., 2014; Tobin et al., 2015). This paper provides a synthesis of the principal deep-marine clastic systems that accumulated in the northern Shikoku Basin (i.e., inputs to the Nankai subduction zone). We interpret their evolution in the context of an evolving, regional-scale history of plate interactions.

A better understanding of the lithostratigraphic units in the Shikoku Basin, their detrital provenance, and their mechanisms of sediment transport and deposition is an important component of the NanTroSEIZE research because the composition and physical-hydrological properties of the sediments affect fluid production and fault-slip behavior during subduction (Underwood, 2007; Saffer et al., 2008; Saffer and McKiernan, 2009; Brown et al., 2011). Clay dehydration reactions in altered basaltic basement might also be a significant source of fluid (e.g., Kameda et al., 2011). Knowledge about the stratigraphic architecture of sand bodies improves predictions of where fluid flow might be focused through high-permeability sheets or meandering shoestring sands, and about locations where excess pore-water pressure might build up at lateral pinch-outs of sandy depositional lobes (e.g., Bredehoeft et al., 1988; Yardley and Swarbrick, 2000). Pore pressure within the accretionary prism is especially important to consider because it influences the taper angle of the wedge, wedge mechanics, initiation of slip on the plate-boundary megathrust, and various fault-slip behaviors, ranging from stable sliding to slow slip events, large earthquakes, and tsunamis (e.g., Ujiie et al., 2003; Tsuji et al., 2005; Saffer and Bekins, 2006; Tobin and Saffer, 2009; Seno, 2009; Saffer and Tobin, 2011; Kameda et al., 2015; Saffer and Wallace, 2015).

Our objective in this paper is to summarize what is known about the history of sedimentation within the Shikoku Basin, with an emphasis on recent drilling results from IODP Sites C0011 and C0012 (Fig. 2; Underwood et al., 2010; Expedition 333 Scientists, 2012a). We supplement that new information with older results from Site 297 of the Deep Sea Drilling Project (DSDP; Karig et al., 1975) and Sites 808, 1173, and 1177 of the

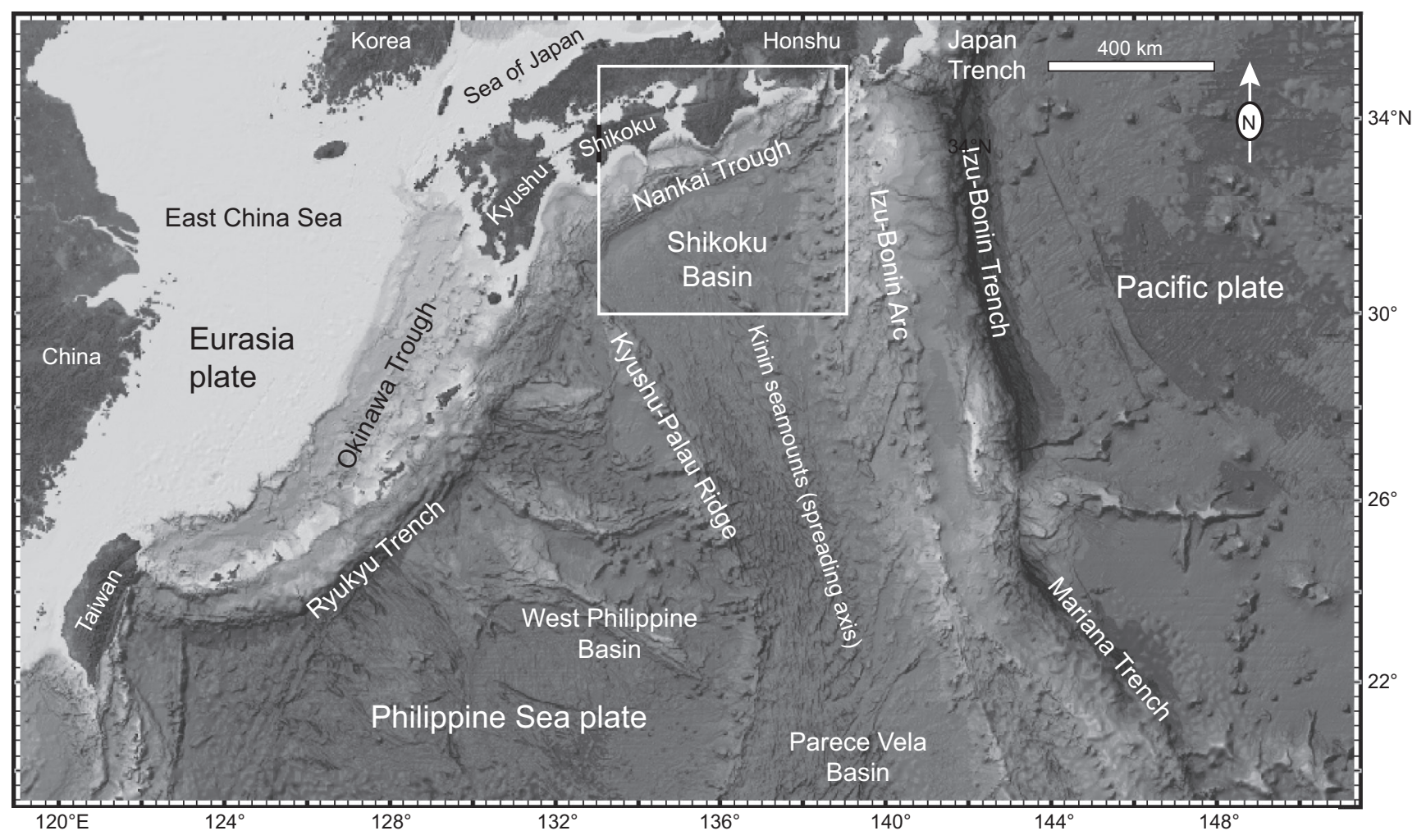

Figure 1. Index map of the northern Philippine Sea region. Box outlines study area shown in Figure 2. 


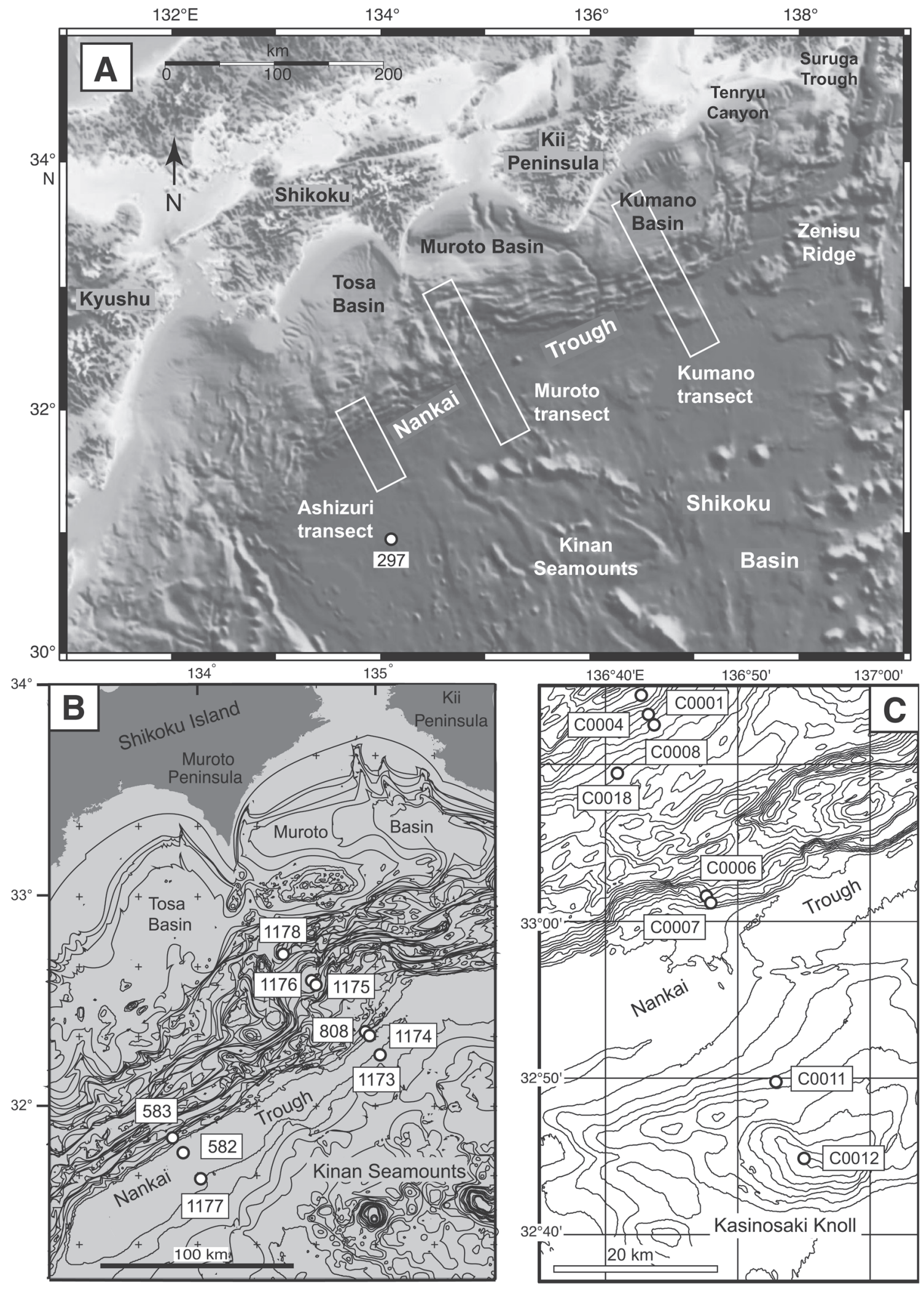

Figure 2. (A) Map of the Shikoku Basin and Nankai Trough study areas, with locations of Kumano, Muroto, and Ashizuri transects and drilling sites. (B-C) Enlarged maps showing locations of Deep Sea Drilling Project (DSDP), Ocean Drilling Program (ODP), and Integrated Ocean Drilling Program (IODP) sites. 
Ocean Drilling Program (ODP; Fig. 2; Taira et al., 1992; Moore et al., 2001a). The Shikoku Basin is unusual when viewed from a global perspective of marine sedimentology because the basin formed on the back-arc side of the Izu-Bonin intraoceanic subduction zone (Fig. 1), and yet the plate is subducting beneath a continental arc. In stark contrast to pelagic-hemipelagic inputs to the Japan Trench (Kimura et al., 2012; Kameda et al., 2015) and Costa Rica (Spinelli and Underwood, 2004; Underwood, 2007), the Nankai-Shikoku depositional system has been strongly affected by tectonic events around its perimeter. The facies character of the basin has adjusted to a multitude of allocyclic mechanisms throughout its history, including primary basement relief inherited from seafloor spreading and seamount volcanism in the back-arc, episodic volcanic-arc activity along two of its sides, triple junction migration and repeated reorganization of the proto-Nankai subduction boundary, discrete phases of collision between the Izu-Bonin and SW Japan (Honshu) arcs, opening of the Okinawa Trough back-arc basin, initiation of intraoceanic subduction along the Ryukyu Trench, and subduction-driven uplift across the Japanese hinterland (Fig. 1). Not surprisingly, virtually all of the major facies boundaries across the basin are diachronous. Sandy depositional systems (channels and lobes) are concentrated in lower to intermediate levels of the stratigraphy, contradicting the generic paradigm in which subduction inputs are supposed to thicken and coarsen upward as an oceanic plate moves closer to its subduction front (Piper et al., 1973). This paper provides a regional-scale overview of the causes and effects of those facies changes. We focus on three specific aspects of that depositional history: the onset of volcanic-ash influx to the basin; the origin and spatial extent of major sand bodies (submarine fans); and gradual changes through time in the composition of detrital clay mineral assemblages.

\section{PLATE-BOUNDARY RECONSTRUCTIONS}

The Shikoku Basin is one of several prominent back-arc or marginal basins in the western Pacific Ocean (Karig, 1971; Seno, 1985; Jolivet et al., 1989). Shikoku Basin occupies the northeastern part of the Philippine Sea plate (Fig. 1), and the Parece Vela Basin represents its extension to the south (Kasuga and Ohara, 1997; Okino et al., 1999; Yamashita et al., 2007). Such basins typically originate through rifting of an island arc and spreading between the remnant and active volcanic edifices (Karig, 1974; Taylor and Karner, 1983; Martinez et al., 2007; Stern, 2010). Sedimentation within back-arc basins is modulated by a variety of factors, including proximity to volcanic eruptions in the adjacent arc, thermal decay and subsidence of basement, directions of prevailing winds that dominate eolian transport, and biogenic productivity (Karig and Moore, 1975; Marsaglia, 1995; Marsaglia et al., 1995). Evolutionary facies models for back-arc basins typically show coarsening and thickening of volcaniclastic deposits toward the active arc, progradation of a volcaniclastic apron toward the remnant arc, and changes in the pelagic sediments from biogenic oozes to red-brown clays as portions of the basin floor subside below the calcite compensation depth. Those firstorder patterns can be perturbed by resedimentation of carbonates by turbidity currents and debris flows (Klein, 1985). In addition, some marginal basins, such as the Shikoku Basin, are flanked on one side by a continental landmass (Fig. 1). That type of configuration increases the potential for multidirectional influx of terrigenous sediments by sediment gravity flow.

The lithosphere beneath Shikoku Basin began to form around $30 \mathrm{Ma}$ in response to Izu-Bonin back-arc rifting and seafloor spreading along the eastern part of the Philippine Sea plate (Watts and Weissel, 1975; Kobayashi and Nakada, 1979; Seno and Maruyama, 1984; Chamot-Rooke et al., 1987; Taylor, 1992; Okino et al., 1994, 1999; Kobayashi et al., 1995; Sdrolias et al., 2004). The Kyushu-Palau Ridge to the west (Fig. 1) represents the remnant Eocene-Oligocene arc (Ishizuka et al., 2011a). A bathymetric partition separates the Shikoku Basin from the West Philippine Basin (Fig. 1). Variations in crustal thickness and magnetization of oceanic crust across the width of the basin have been attributed to differences in magma supply at the time of seafloor spreading and asymmetric spreading (Kido and Fujiwara, 2004; Ishihara and Koda, 2007). The direction of spreading rotated at ca. 20-19 Ma from ENE-WSW to NE-SW (Sdrolias et al., 2004). The Kinan seamount chain (Fig. 1), which trends roughly N-S down the center, is built on vestiges of the extinct spreading axis. Organized spreading evidently ceased ca. $15 \mathrm{Ma}$, but scattered eruptions on seamounts continued to as recently as 8-7 Ma (Ishii et al., 2000; Sato et al., 2002; Ishizuka et al., 2009).

Estimates for the current rate of relative plate motion across the Nankai Trough subduction boundary range from $2.5 \mathrm{~cm} / \mathrm{yr}$ (Ranken et al., 1984) to 4.0-5.0 cm/yr (Seno, 1977; Zang et al., 2002), but that vector is not representative of the last 30 m.y. of subduction history. Furthermore, plate-tectonic adjustments across the broader regions near Japan included several noteworthy events that must have affected delivery and transport of sediment into the nearby Shikoku Basin (e.g., Maruyama et al., 1997; Taira, 2001; Isozaki et al., 2010). We consider in the next paragraphs the following highlights of that history: (1) rifting and subsequent opening of the Sea of Japan during the late Oligocene to middle Miocene, accompanied by rapid clockwise rotation of southwest Japan; (2) initiation of subduction of the Philippine Sea plate along the proto-Nankai margin during the middle Miocene, accompanied by widespread, near-trench magmatism across the Outer Zone of Japan; (3) a shift during the late Miocene from nearorthogonal subduction to left-lateral strike-slip, oblique slip, or unusually slow subduction along western and central segments of the proto-Nankai margin; (4) reestablishment of near-orthogonal convergence and accelerated subduction of the Philippine Sea plate occurring in the wake of a triple junction as it migrated toward the northeast; (5) a series of Pliocene-Quaternary collisions near the northeastern end of Nankai Trough between the Honshu arc and basement highs of the Izu-Bonin arc; and (6) rifting and spreading of the back-arc Okinawa Trough from late Miocene to Quaternary, and associated buildup of bathymetric/topographic relief along the adjacent Ryukyu arc-trench system. We emphasize here 
that the exact timing of these events remains somewhat uncertain, as do the exact positions of the evolving plates and their boundaries at various points in time. That temporal and spatial uncertainty is particularly important to consider for triple-junction migration and related effects. In the following text, we elaborate on each of these changes in regional tectonics.

The plate-tectonic reconstructions of Hall (2002, 2012), Mahony et al. (2011), Seton et al. (2012), von Hagke et al. (2016), and Wu et al. (2016) show subduction of the Pacific plate as the dominant process in southwest Japan prior to ca. 16 Ma, with a trench extending from Hokkaido to Kyushu and beyond. The Shikoku Basin at that time probably was separated from southwest Japan by a salient of the Pacific plate (Hibbard and Karig, 1990). To the north of the Japanese Islands, the Sea of Japan first started to open via seafloor spreading ca. $28 \mathrm{Ma}$, as indicated by the oldest magnetic anomaly in the Japan Basin (Tamaki, 1995). Continued opening of that marginal basin resulted in a "doubledoor" style of rotation that produced bent structural trends in the crustal blocks of southwest and northeast Japan (Otofuji et al., 1985, 1986; Celaya and McCabe, 1987; Faure and Lalevee, 1987; Martin, 2011). Counterclockwise rotation of northeast Japan triggered eruptions of low-K tholeiitic basalts in the forearc of the Japan Trench (Yamamoto and Hoang, 2009). In southwest Japan, the sense of rotation was clockwise; that rapid motion began ca. $18 \mathrm{Ma}$ and ceased by ca. $15 \mathrm{Ma}$ (Otofuji, 1996; Ishikawa, 1997; Otofuji et al., 1999; Hoshi and Sano, 2013; Hoshi et al., 2015). The first collisions between the Honshu arc and basement highs along the axis of the Izu-Bonin arc also started during that Miocene time period (Niitsuma, 1989; Amano, 1991; Soh et al., 1991; Takahashi and Saito, 1997; Hoshi and Sano, 2013).

Rapid rotation of southwest Japan during the Miocene triggered a form of induced subduction initiation (e.g., Stern, 2004; Leng and Gurnis, 2011). The Philippine Sea plate evidently started its descent beneath the proto-Nankai Trough just before the Shikoku Basin spreading center went extinct ca. $15 \mathrm{Ma}$. Manifestations of subduction of young and unusually warm lithosphere (including the extinct spreading center) are largely represented in the form of anomalous near-trench magmatism, which spread across the Outer Zone of Japan (Hibbard and Karig, 1990; Kimura et al., 2005). The oldest of those magma bodies is $16.8 \pm 0.8 \mathrm{Ma}$, and most ages cluster around $15 \mathrm{Ma}$ (Hasebe et al., 2000; Hasebe and Hoshino, 2003; Orihashi et al., 2007; G. Kimura et al., 2014). The near-trench volcano-plutonic complex included I-type granites, S-type granites, rhyolitic lavas, and rhyolitic ash-flow deposits derived from large caldera eruptions (Kawakami and Hoshi, 2007; Miura and Wada, 2007; Shinjoe et al., 2007). Granitic and basaltic magmas were also intruded into accreted sedimentary rocks and forearc-basin deposits along the strike-length of the Shimanto belt. Allowing for at least 1 m.y. of lag time for the nascent subducting slab to generate flux melting (e.g., Ishizuka et al., 2011b), we estimate the timing of subduction initiation to be ca. $18 \mathrm{Ma}$.

By ca. 14-13 Ma, magmatism across southwest Japan shifted to the north and became better organized along the belt of
Setouchi high-Mg andesites (Shimoda et al., 1998; Tatsumi et al., 2001; Tatsumi, 2006; J.-I. Kimura et al., 2014). Geochemical evidence from those volcanic rocks is consistent with extensive melting of subducting sediments (Shimoda et al., 1998, 2003). Overlapping that time period, from ca. 17 to ca. $11 \mathrm{Ma}$, the triple junction at the juncture of the Pacific, Philippine Sea, and Eurasia plates appears to have migrated toward the northeast, as indicated by a crude spatial pattern for the ages of anomalous near-trench magma bodies (G. Kimura et al., 2014). Kyushu experienced a long period of quiescence in subduction-related volcanism from ca. $10 \mathrm{Ma}$ to ca. $6 \mathrm{Ma}$, and that gap has been attributed to either sinistral strike-slip motion or pronounced deceleration of plate convergence (Kamata and Kodama, 1994; Mahony et al., 2011). We do not know exactly how far the sinistral boundary extended to the northeast, but the entire strike-length of the proto-Nankai margin may have been transcurrent during that interval of time.

The band of subalkalic arc volcanoes in northeast Japan (i.e., eruptive products of Pacific plate subduction) remained largely stationary from ca. $15 \mathrm{Ma}$ through the Quaternary (Uto and Tatsumi, 1996; Kimura et al., 2005; Acocella et al., 2008). In contrast, motion of the Philippine Sea plate changed dramatically at ca. $6 \mathrm{Ma}$, which increased subduction rates and/or reestablished roughly trench-normal subduction along the entire Nankai Trough (Kamata and Kodama, 1994, 1999; Itoh and Nagasaki, 1996). Those changes greatly affected patterns of magmatism and deformation across southwest Japan. Studies of mantle tomography reinforce this idea of recently renewed subduction. The seismic slab-subduction depths for the Philippine Sea plate extend only to $\sim 60 \mathrm{~km}$, consistent with limited distances of subduction beneath the Kii Peninsula, Shikoku, and Kyushu (Honda and Nakanishi, 2003; Nakajima and Hasegawa, 2007; Iidaka et al., 2009; Zhao, 2012; Zhao et al., 2012; Wu et al., 2016). In comparison, the subducting Pacific plate slab can be traced to depths of $\sim 500 \mathrm{~km}$ beneath Hokkaido and northern Honshu (Nakajima et al., 2009; Zhao et al., 2012). Reestablishment of near-orthogonal convergence along the Nankai Trough resulted in a series of collisions between bathymetric highs along the Izu-Bonin arc and the Honshu arc (Ogawa et al., 1985; Niitsuma, 1989; Amano, 1991; Kitazato, 1997; Soh et al., 1998). In addition, scattered andesitic volcanism returned to Kyushu by ca. 5 Ma (Kamata, 1989; Mahony et al., 2011, 2016).

Convergence along the Nankai Trough plate interface changed again at ca. $2 \mathrm{Ma}$, when the convergence vector for the Philippine Sea plate rotated to the northwest (Wu et al., 2016). Across Kyushu, the magmatic arc established itself fully during that time and became increasingly dominated by explosive calderas and large ignimbrite eruptions (Kamata and Kodama, 1999; Mahony et al., 2011, 2016). That region was also affected by widespread, crustal-scale deformation (Kamata, 1989; Kodama et al., 1995; Itoh et al., 1998; Okamura, 2016). There is complementary evidence at the southwest end of the Nankai Trough for rapid, along-strike migration of the collision point between Kyushu and the aseismic Kyushu-Palau Ridge (Wallace et al., 2009). At the eastern end of Nankai Trough, the volcanic 
Underwood and Pickering

front near the Izu-Honshu collision zone migrated to the west in response to redirection of the subduction vector for the Philippine Sea plate (Nakamura et al., 2014). The geologic and topographic responses to that collision also intensified during the Quaternary, as shown by rapid rates of uplift, exposure of midcrustal tonalite and granodiorite plutons, and widespread deformation around the collision zone (Kitazato, 1997; Saito et al., 1997; Kawate and Arima, 1998; Soh et al., 1998; Hirono, 2003; Okamura, 2003; Yamaji et al., 2003; Yamamoto and Kawakami, 2005; Hashima et al., 2016). Offshore, lithospheric shortening from the collision triggered low-angle thrust faulting seaward of the eastern Nankai Trough and creation of the Zenisu Ridge in the subducting basement (Chamot-Rooke and Le Pichon, 1989; Lallemant et al., 1989; Mazzotti et al., 2002). Tomographic images indicate that the entire Izu-Bonin arc is now subducting under the Honshu arc (Yamamoto et al., 2009).

At the present time, the Ryukyu Trench, islands of the Ryukyu volcanic arc, and the Okinawa Trough separate the East China Sea from the northeastern edge of the West Philippine Basin and northwest Shikoku Basin (Fig. 1). Those bathymetric obstructions, however, did not exist during the early to middle Miocene (e.g., Letouzey and Kimura, 1986; Sibuet et al., 1995). Andesitic volcanoes along the Ryukyu arc grew above a basement of accreted sedimentary and metamorphic rocks that are broadly correlative with the Shimanto belt of southwest Japan (Kizaki, 1986; Ujiie, 1997; Schoonover and Osozawa, 2004). That accretionary prism, however, is probably a product of Pacific plate subduction rather than subduction of the Philippine Sea plate (Hibbard and Karig, 1990; Seton et al., 2012; von Hagke et al., 2016; Wu et al., 2016). To the north, the continental margin of the East China Sea shows widespread evidence for extensional faulting of continental basement beneath the continental shelf (Cukur et al., 2011; Gungor et al., 2012). Rifting of the shelf began in the Late Cretaceous and resulted in the creation of several sedimentary basins separated by buried continental ridges or rifted remnants of proto-Ryukyu arc basement (Sibuet et al., 1987). Multiple phases of uplift (basin inversion) also affected the shelf (Yang et al., 2004; Lee et al., 2006; Cukur et al., 2011; Yang et al., 2011).

Differences of opinion exist with regard to the timing of initial rifting and early stages of seafloor spreading in the Okinawa Trough (Fig. 1), depending, in part, on the types of data used to make such reconstructions. The estimates range from younger than 2.6 Ma (Kimura, 1985; Park et al., 1998) to 7-2 Ma (Sibuet et al., 1998), to 10-6 Ma (Miki, 1995), and 13-7 Ma (Sibuet et al., 1987; Gungor et al., 2012). Given our focus on the Shikoku Basin, the key question in that history is: When did bathymetric/topographic relief grow enough to inhibit or block sediment transport from the shelf edge toward the south? The paleotectonic reconstructions of Gungor et al. (2012) are the most detailed in that regard; they show formation of a small rift basin (Ho Basin) between a basement high (Longwan Ridge) and the proto-Ryukyu Trench during the middle Miocene (15.9-11.6 Ma). According to Gungor et al. (2012), opening of the Okinawa Trough and growth of the Ryukyu arc volcanoes to elevations above sea level did not occur until the late Miocene. Thus, we conclude that the requisite seafloor relief probably was in place by ca. $7 \mathrm{Ma}$.

\section{BASINWIDE CORRELATION OF LITHOFACIES}

\section{Lithologic Character and Age of Facies Units}

Reorganizations of the plate boundaries and centers of arc volcanism, as summarized herein, must have influenced the detrital sources and pathways of sediment delivery to the Shikoku Basin throughout its evolution, particularly toward its northern reaches in closer proximity to continental watersheds. Seismicreflection data show that the total thickness of sediment decreases toward the south; sediments in the southern part of the Shikoku Basin are thin and discontinuously distributed in depressions developed on the irregular basement (Higuchi et al., 2007). Distal parts of the basin were cored, intermittently, during DSDP Leg 58 (Klein and Kobayashi, 1981). The deposits at Sites 442, 443 , and 444 consist largely of hemipelagic mud with scattered tephra layers (Curtis and Echols, 1980; Furuta and Arai, 1980; White et al., 1980). The isotopic signatures of those fine-grained sediments seem to require input from sources that were external to the basin's margins, probably via eolian transport from eastern Eurasia (Mahoney, 2005). Mahoney (2005) further suggested that sharp fluctuations of those isotopic signatures represent episodes of basin-margin volcanism (e.g., from the Izu-Bonin arc) superimposed on a background of steady hemipelagic sedimentation.

Paleogeographic reconstructions for proximal parts of the Shikoku Basin have benefited from new information gathered during IODP Expeditions 322 and 333 (Fig. 2). Those coring results from the Kumano transect reinforce earlier ideas regarding variations in lithostratigraphy along strike (Underwood, 2007), as demonstrated by differences between Site 1177 (Ashizuri transect) and Sites 1173, 1174, and 808 (Muroto transect; Fig. 2). Two new sites were cored on the Philippine Sea plate just seaward of the Nankai Trough (Underwood et al., 2010; Expedition 333 Scientists, 2012a). Site C0011 is located on the northwest flank of a prominent bathymetric high (Kashinosaki Knoll), and Site C0012 is located near the crest of the knoll (Fig. 3). Because of operational failures and insufficient allocations of time, drilling terminated $\sim 200 \mathrm{~m}$ above basement at Site C0011 (Figs. 3 and 4). The upper intervals at both sites (Figs. 4 and 5) were not cored until Expedition 333 (Expedition 333 Scientists, 2012a). At Site 1173, deposits of Shikoku Basin are overlain by a Quaternary trench-wedge facies (Fig. 6). Coring at Site 1177 (Ashizuri transect) commenced at $300 \mathrm{~m}$ below the seafloor (mbsf; Fig. 7), so sediments younger than ca. $2 \mathrm{Ma}$ (including the trench wedge) were not sampled there. Synthesis of these drilling results allows us to define five first-order lithofacies units, as described below. Most of the facies boundaries are diachronous, and some of the facies do not extend across the entire basin (Fig. 8).

The uppermost lithologic unit with the Shikoku Basin is a hemipelagic-pyroclastic facies consisting of bioturbated silty 
clay with abundant intercalations of fine to coarse volcanic ash, typically with unaltered glass shards. Deposition of those sediments occurred predominantly by settling of suspended mud and air-fall tephra. We correlate such deposits along the Kumano transect with units that previous investigators along the Muroto and Ashizuri transects had designated as the "upper Shikoku Basin" facies (Taira et al., 1992; Moore et al., 2001a). Initially, the lower boundary of the upper Shikoku Basin facies was defined by the deepest occurrence of discrete volcanic ash layers at Site 808 (Shipboard Scientific Party, 1991). If we adhere to that definition, it is clear that the basal age of the facies varies considerably along strike (Fig. 8). The ages are: 7.6 Ma at Site C0011 (Fig. 4); 7.8 Ma at Site C0012 (Fig. 5); $3.3 \mathrm{Ma}$ at Site 1173 (Fig. 6); and 3.9 Ma at Site 1177 (Fig. 7).

The choices listed earlier herein for unit boundaries remain open to question. For example, shipboard scientists may have pushed the boundary at Site 1173 higher up section than warranted. Their choice for the unit boundary also took into account a match with sharp changes in sediment physical properties (Shipboard Scientific Party, 2001a). To complicate matters further, heat flow is unusually high along the Muroto transect, which is near the axis of the Kinan seamounts (Yamano et al., 2003), and enhanced levels of diagenesis may have obscured visual recognition of some thin ash beds (Spinelli et al., 2007). Here, we call attention to an increase in the rate of sedimentation at $400 \mathrm{mbsf}$ (Fig. 6); that inflection point in the age-depth model may be a more reliable indicator of the primary facies change. The age of sediment at that depth is ca. 4.0 Ma, which is closer to the age of the facies boundary at Site 1177, where effects of volcanic ash alteration are absent (Spinelli et al., 2007).

Along the Kumano transect (Fig. 3), an abrupt downhole facies change to a distinctive tuffaceous sandstone occurs at $\sim 350$ mbsf (Site C0011) and at 150 mbsf (Site C0012; Underwood et al., 2010). This volcanic turbidite facies does not exist along the Muroto and Ashizuri transects (Fig. 8). Point counts of smear slides showed that the upper interval of tuffaceous sandstone is composed of $>25 \%$ pyroclasts and fresh volcanic glass, whereas an underlying interval of volcaniclastic sandstone contains $<25 \%$ pyroclastic grains and more sedimentary-lithic grains (Underwood et al., 2010; Kutterolf et al., 2014). The basal age of the volcanic turbidite facies is $9.1 \mathrm{Ma}$ at C0011 (Fig. 4) and 9.4 Ma at C0012 (Fig. 5).

Beneath the volcanic turbidites, we find a hemipelagic facies composed of monotonous bioturbated silty claystone (Fig. 3). Minor lithologies include thin beds of micrite and calcareous claystone. This facies extends across the entire basin (Fig. 8). The mudstone deposits at Site C0012 contain an interval with bedding inclined at angles of $40^{\circ}$ to $45^{\circ}$. From seismic character and

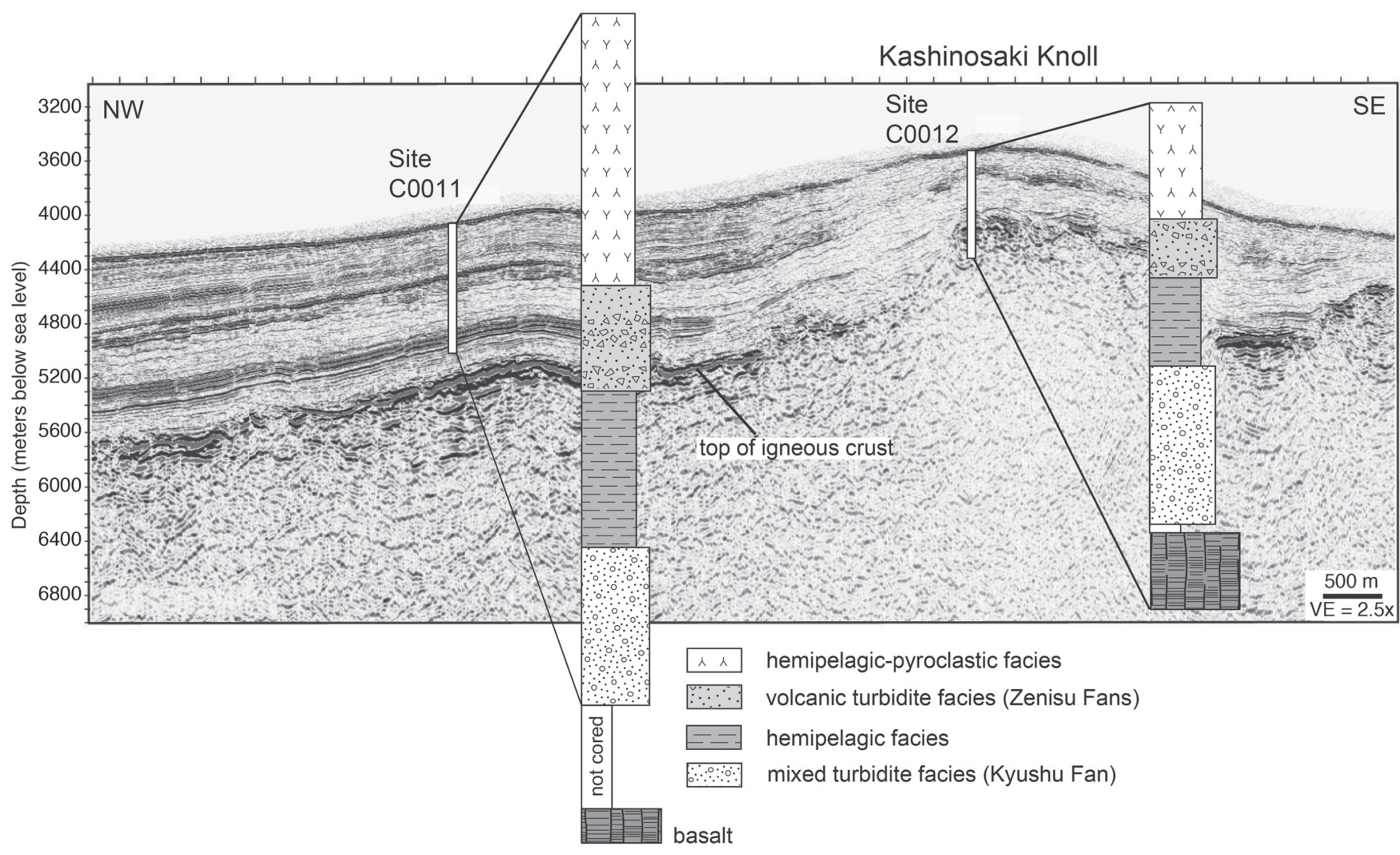

Figure 3. Seismic-reflection profile crossing Kashinosaki Knoll (from Underwood et al., 2010) with distribution of lithofacies units at Integrated Ocean Drilling Program (IODP) Sites C0011 and C0012 (Kumano transect); mbsl—m below sea level; VE—vertical exaggeration. 


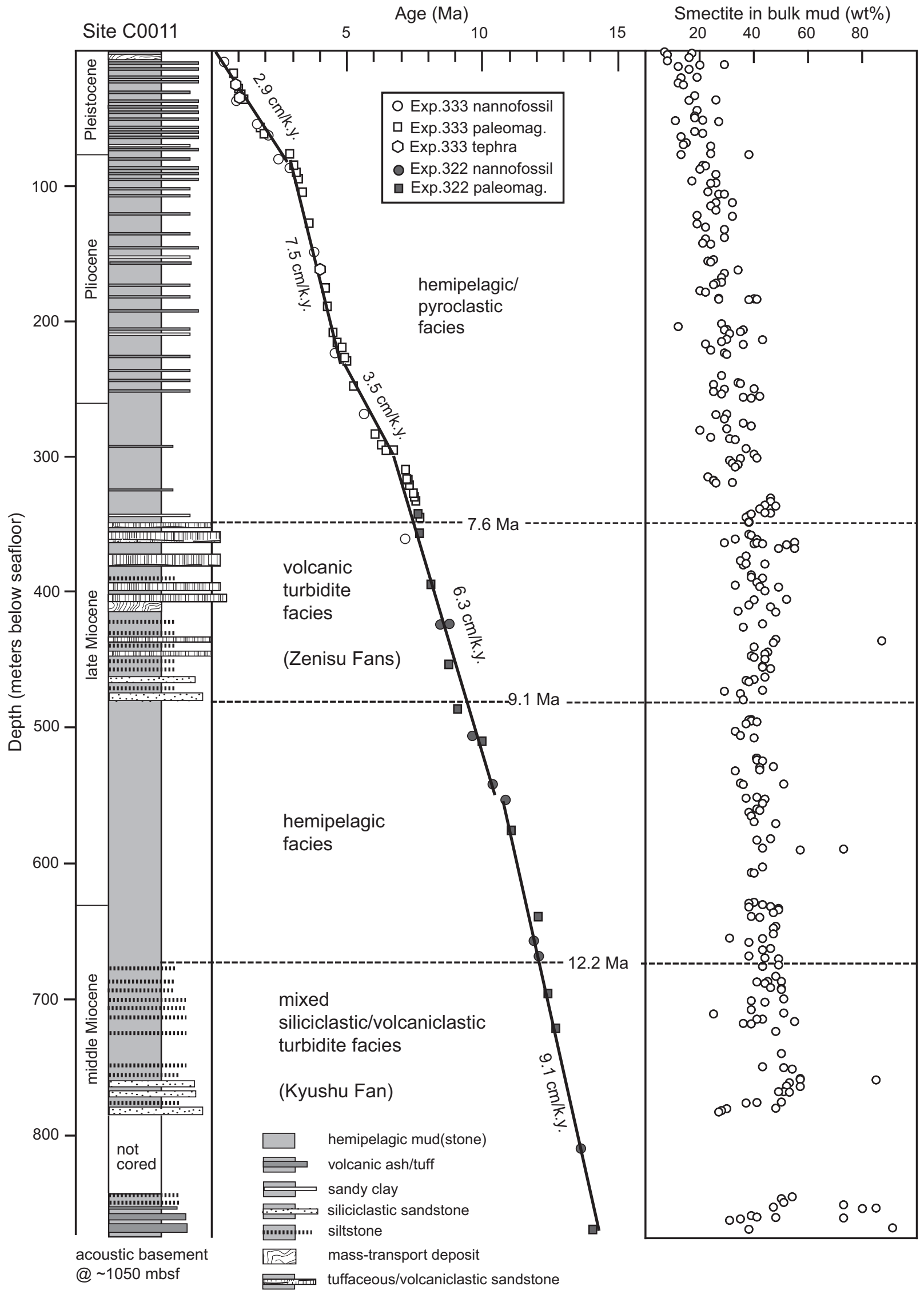


Figure 4. (A) Integrated age-depth model for Integrated Ocean Drilling Program (IODP) Site C0011, with lithofacies unit boundaries and rates of sediment accumulation (uncorrected for compaction). Age control is from Expedition 322 Scientists (2010a) and Expedition 333 Scientists (2012b). (B) Stratigraphic changes in relative abundance of smectite plotted as wt\% of the bulk sediment (data from Underwood and Guo, 2013, 2017).

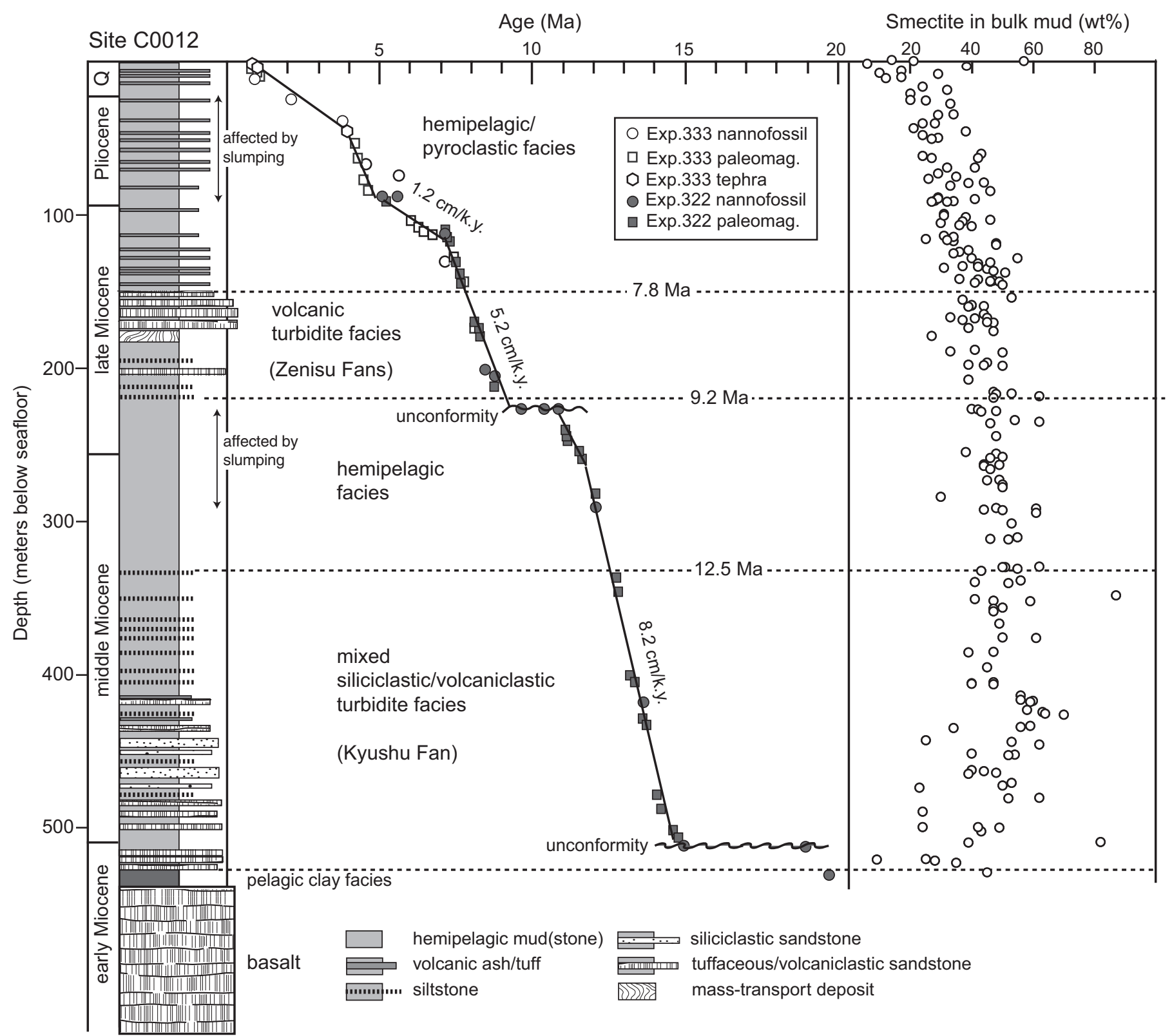

Figure 5. (A) Integrated age-depth model for Integrated Ocean Drilling Program (IODP) Site C0012, with lithofacies unit boundaries and rates of sediment accumulation (uncorrected for compaction). Age control is from Expedition 322 Scientists (2010b) and Expedition 333 Scientists (2012c). (B) Stratigraphic changes in relative abundance of smectite expressed as wt\% of the bulk sediment (data from Underwood and Guo, 2013, 2017). Q-Quaternary. 


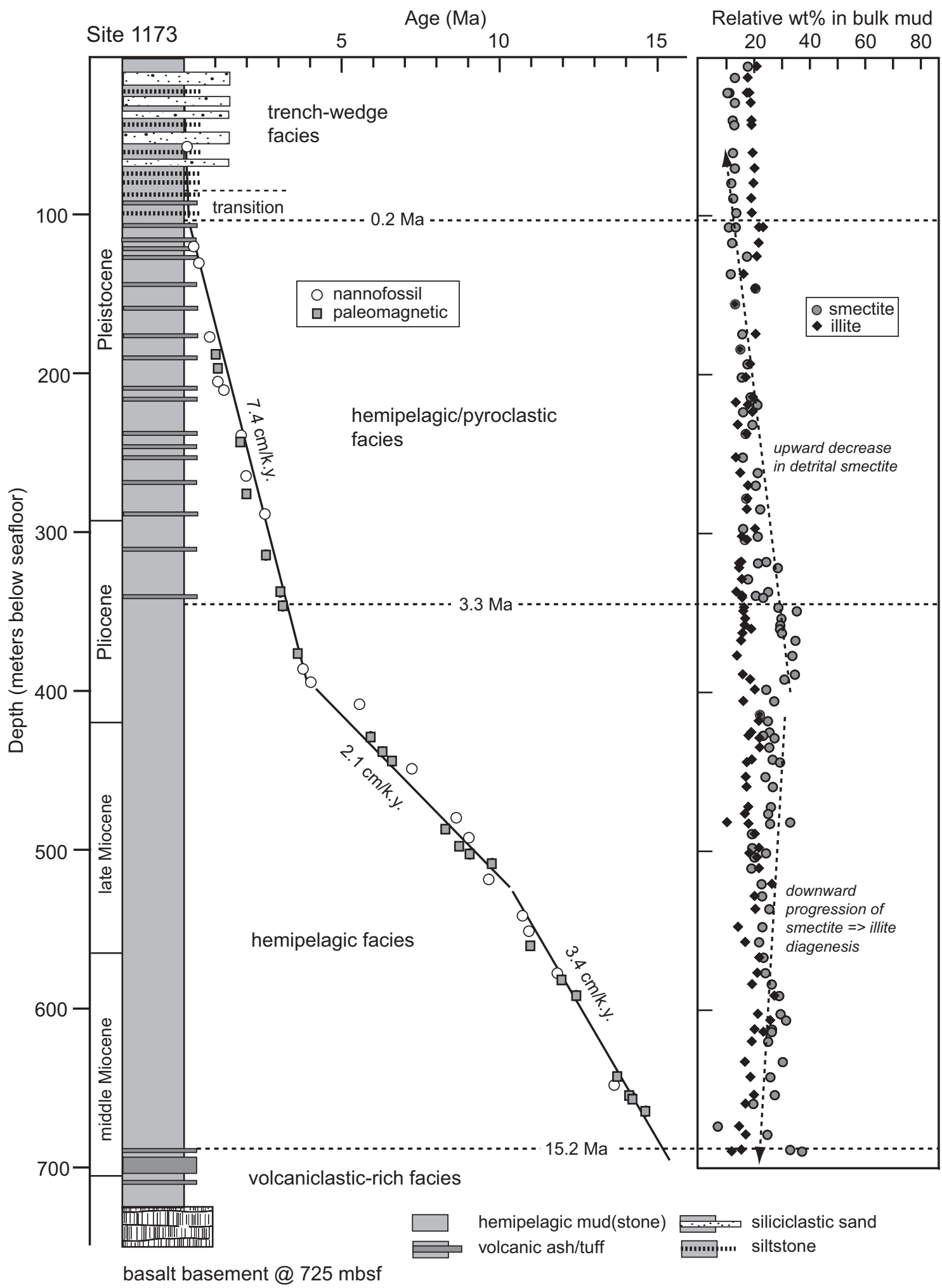

Figure 6. (A) Integrated age-depth model for Ocean Drilling Program (ODP) Site 1173 (Muroto transect), with lithofacies unit boundaries. Age control is from Shipboard Scientific Party (2001a). (B) Stratigraphic changes in relative abundances of illite (blue diamonds) and smectite (red circles) expressed as wt $\%$ of the bulk sediment (data from Steurer and Underwood, 2003). The reduction of smectite with depth is a result of smectite-to-illite diagenesis. 


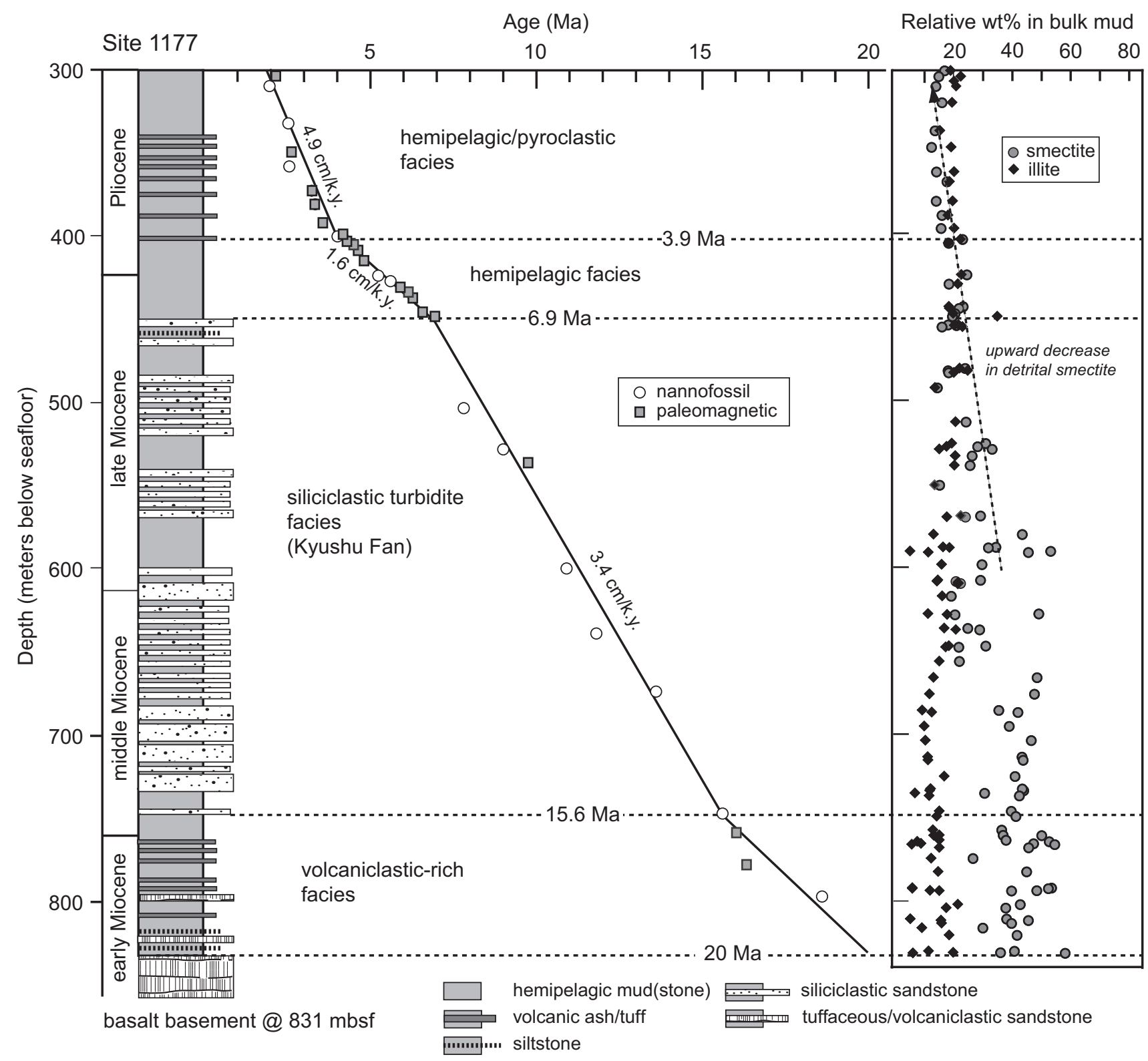

Figure 7. (A) Integrated age-depth model for Ocean Drilling Program (ODP) Site 1177 (Ashizuri transect), with lithofacies unit boundaries. Age control is from Shipboard Scientific Party (2001b). (B) Stratigraphic changes in relative abundances of illite (blue diamonds) and smectite (red circles) expressed as wt\% of the bulk sediment (data from Steurer and Underwood, 2003).

core-scale deformation structures, this zone of disruption appears to be associated with listric normal faults on the north-inclined flank of Kashinosaki Knoll (Underwood et al., 2010). Nannofossil datums also indicate an angular unconformity near the top of this interval with a hiatus of $\sim 2$ m.y. (Fig. 5).

The base of the hemipelagic facies is generally defined by the uppermost appearance of fine-grained turbidites; the age of that facies change is $12.2 \mathrm{Ma}$ at Site C0011 (Fig. 4), 12.7 Ma at Site C0012 (Fig. 5), and 6.9 Ma at Site 1177 (Fig. 7). The hemipelagic facies at Site 1173 (Figs. 6 and 8) extends almost to the base of the sediment column (to an age of $15.2 \mathrm{Ma}$ ), presumably due to isolation of the Kinan basement high from transport by Miocene turbidity currents (Underwood, 2007). In fact, Miocene turbidites were not recovered from any sites above the subducting Kinan basement high (Sites 808, 1173, 1174). Seismic-reflection data, however, do reveal isolated pockets of probable turbidites in basement lows along the N-S strike-length of the seamounts (Moore et al., 2001b).

At Site 1177, four intervals of siliciclastic turbidites were recovered from the lower half of the Shikoku Basin, ranging in age from 15.6 to $6.9 \mathrm{Ma}$ (Fig. 7). Those thin-bedded siliciclastic sandstones are consistently lithic-rich layers with abundant 


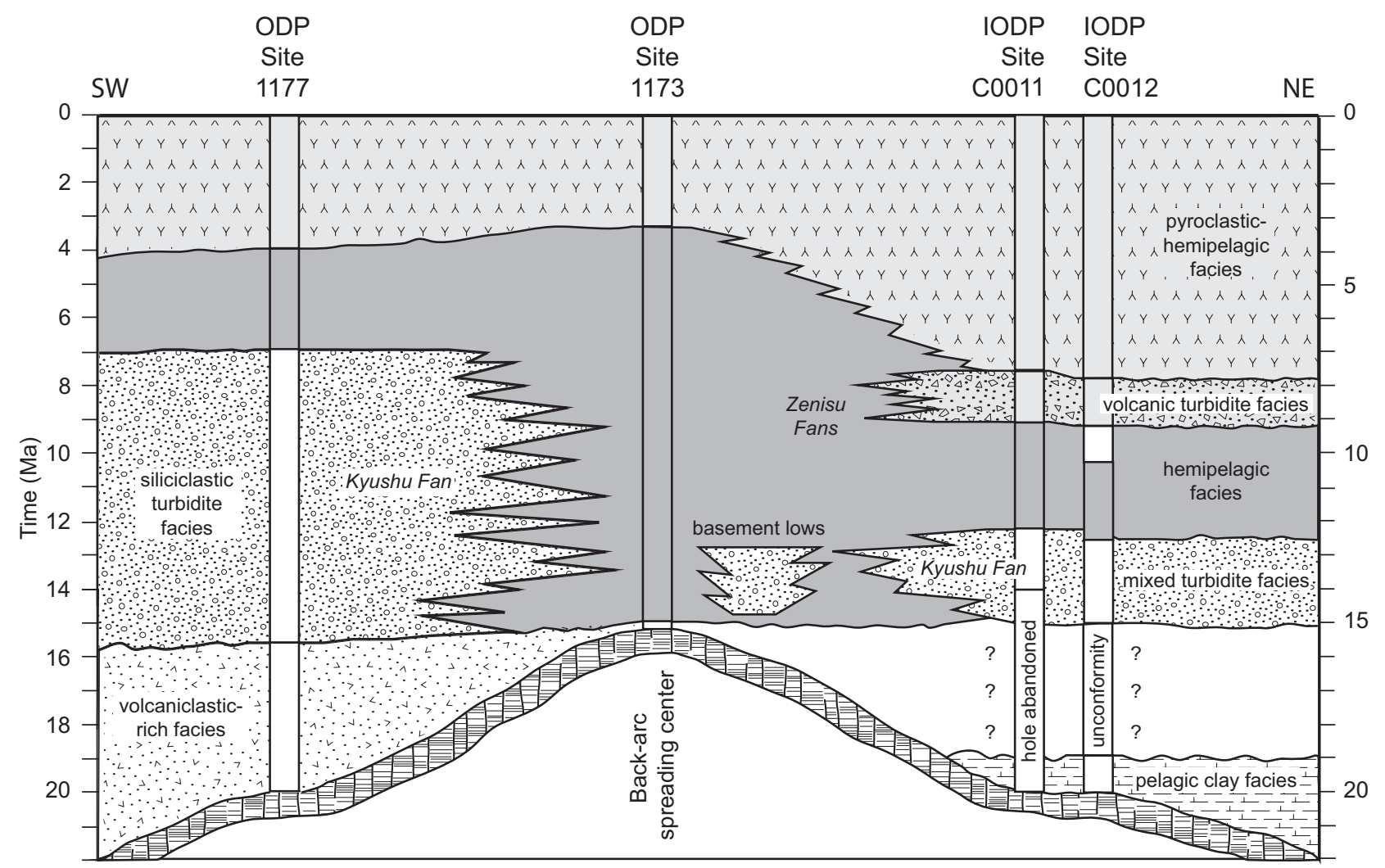

Figure 8. Schematic illustration of the time-space distribution of lithofacies units across the northern Shikoku Basin. Orientation of the section is roughly parallel to the trench axis and passes through "reference sites" for the Ashizuri, Muroto, and Kumano drilling transects. ODP_Ocean Drilling Program; IODP_-Integrated Ocean Drilling Program.

terrigenous organic matter. A similar facies was recovered along the Kumano transect (Fig. 3). In its upper parts, bioturbated mudstones are interbedded with normally graded siltstone and fine-grained sandstone. The facies grades down section into coarser tuffaceous sandy mudstone, siliciclastic sandstone, and tuff. Attempts to correlate, in detail, from the flank to the crest of Kashinosaki Knoll were compromised by poor core recovery at Site C0011 (Fig. 4) and by the occurrence of an unconformity between Sites C0011 and C0012. Fission-track ages of sandstone clasts at Site C0011 indicate that the detrital source rocks were $14.7 \pm 0.9 \mathrm{Ma}$ in age; comparable detrital ages for broadly correlative deposits at Site C0012 are $13.0 \pm 0.7 \mathrm{Ma}$ (Pickering et al., 2013). The tuffs at Site C0011 appear to be geochemically similar to thick rhyolitic beds that were recovered near the bottom of Hole 808C (Fig. 2); those strata yielded an age of ca. 13.6 Ma (Taira et al., 1992).

An angular unconformity disrupts the lowermost stratigraphy at Site C0012 at a depth of $~ 510$ mbsf, with an apparent hiatus of $\sim 4$ m.y. (Fig. 5). Smear slides show that sandstones immediately above the unconformity are compositionally diverse; some contain abundant volcanic glass and feldspar, whereas others are enriched in sedimentary-lithic grains, quartz, and heavy minerals (Expedition 322 Scientists, 2010b). Their heterogeneous com- positions, textures, and ages are comparable to the lowermost volcaniclastic-rich facies at Site 1177 (Fig. 7).

Drilling was terminated at Site C0011 well above the sediment-basement interface (Fig. 4), but at Site C0012, the basal lithofacies of pelagic claystone is a 9.3-m-thick interval composed of variegated calcareous claystone, rich in nannofossils (Fig. 5). The pelagic claystone accumulated in direct contact with basalt, and its mottled red-green coloration is probably due to iron reduction. Nannofossils from the claystone indicate that the basalt beneath Kashinosaki Knoll is older than 18.9 Ma, similar to the projected basement age at Site 1177. Basalt was merely tagged at Sites 1177 and 1173, but over $100 \mathrm{~m}$ of basalt were cored at Site C0012 (Expedition 333 Scientists, 2012c). Basement at Site C0012 was also logged to a depth of 710 mbsf during Expedition 338 (Strasser et al., 2014).

\section{Turbidite Sand Bodies of Shikoku Basin}

Integration of drilling results with seismic-reflection data (Ike et al., 2008a, 2008b) facilitated mapping the distribution of facies units over larger areas of Shikoku Basin (Fig. 9). Coring at Sites C0011 and C0012 verified that intervals with semitransparent to weak reflections correspond to mudstones that were depos- 
Facies architecture, detrital provenance, and tectonic modulation of sedimentation, Shikoku Basin
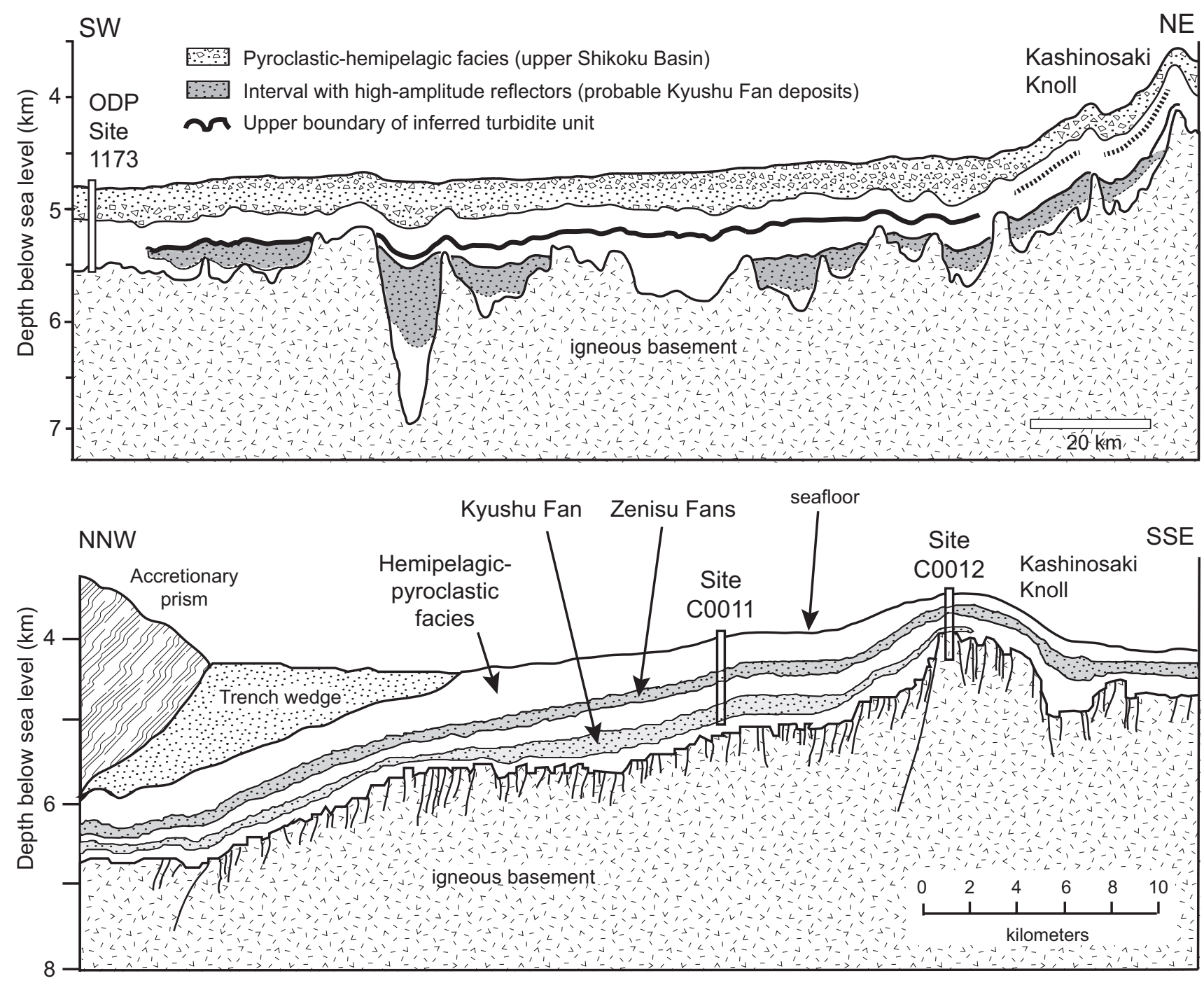

Figure 9. (A) Line drawing interpretation of seismic depth section that crosses Shikoku Basin parallel to the trench through Ocean Drilling Program (ODP) Site 1173 and Kashinosaki Knoll, showing along-strike variations of basement topography associated with sediment thickness and type. Intervals with high-amplitude reflections are highlighted in yellow. See Ike et al. (2008b) for uninterpreted seismic profile. (B) Line drawing interpretation of a composite seismic profile and representative depth section that crosses Shikoku Basin perpendicular to the trench through Integrated Ocean Drilling Program (IODP) Sites C0011 and C0012. Kyushu and Zenisu fans are highlighted in yellow and orange, respectively. See Pickering et al. (2013) for uninterpreted seismic profile.

ited from dilute hemipelagic suspensions. The acoustic character for intervals with sandy sediment gravity flow deposits consists of high-amplitude, continuous to discontinuous reflections. Such deposits occur preferentially within basement lows, as shown by a seismic-reflection profile parallel to the trench axis (Fig. 9). In addition, total sediment thickness is up to six times greater above basement lows than above basement highs (Ike et al., 2008b). As an example, total sediment thickness on the western and northern slopes of Kashinosaki Knoll is $\sim 40 \%-50 \%$ more than on the summit and southeastern slopes (Fig. 3).

The upslope continuity of three sand-bearing acoustic intervals from the flank to the crest of Kashinosaki Knoll (Fig. 3) is perhaps surprising, given its elevation, but by no means unique to that particular bathymetric high (see, for example, Dolan et al., 1989; Völker et al., 2008). Thinning and onlap of older turbidite units against the knoll indicate that the basement high originated as a constructional volcanic edifice rather than by later-stage faulting of the basement (Ike et al., 2008a). The unconformity near the stratigraphic base of Site C0012 is likewise consistent with a steeply inclined seafloor early in its history. Each facies interval thins toward the crest (Fig. 3), so seafloor relief must have been sustained over the knoll's history. Furthermore, the persistence of Kashinosaki Knoll as a bathymetric high seemingly requires upslope flow of turbidity currents (Muck and Underwood, 1990) 
and/or turbidity currents with entrained layers that rose several hundred meters above the flanking abyssal seafloor.

Figure 9 shows the interpretation of a composite seismic profile that crosses from the seaward trench edge through Sites C0011 and C0012. Lower portions of the section display a prominent package of high-amplitude, continuous reflections; coring confirmed that interval to be an upward-fining succession of sandy to silty turbidites, which Pickering et al. (2013) named Kyushu Fan. Its acoustic character is similar to that of the lower Shikoku Basin near ODP Site 1177 and DSDP Site 297 (Fig. 2; Pickering et al., 2013). At Site 1177, the rate of sedimentation for Kyushu Fan (uncorrected for compaction) averaged $3.4 \mathrm{~cm} / \mathrm{k} . \mathrm{y}$. (Fig. 7), which was only marginally faster than the coeval hemipelagic facies at Site 1173 (Fig. 6). At Site C0012, the average rate of sedimentation for the Kyushu Fan interval was $8.2 \mathrm{~cm} / \mathrm{k} . \mathrm{y}$. (Fig. 5). The correlative package of reflections laps onto steep basement slopes around Kashinosaki Knoll but runs parallel to the gentler basement slopes. Thinning and onlap of the acoustic interval to both the south and the north indicate that sediment gravity flows moved oblique to the seismic line (Pickering et al., 2013). The sediment gravity flows also filled in preexisting basement lows to the west (Fig. 9; Ike et al., 2008b).

Core recovery through the depth interval of Kyushu Fan was especially poor at Site C0011, largely because of progressive deterioration and eventual destruction of the drill bit (Expedition 322 Scientists, 2010a). Logging while drilling logs, however, provide an accurate record of the prevalence of sandy sediment gravity flow deposits on the flank of Kashinosaki Knoll. Sandstone beds were not recovered between 660 and $710 \mathrm{mbsf}$, but the logs show thicknesses of 5-7 m, and log responses are indicative of normal (fining-upward) size grading (Fig. 10). A 60-m-thick interval that was not cored contains two prominent sandstone layers, and there are several $10-\mathrm{m}$-scale upward-fining cycles (Fig. 10).

Farther to the west, sandstones correlative with the Kyushu Fan acoustic facies were first recovered during DSDP Leg 31 at Site 297 (Pickering et al., 2013), which is located in western Shikoku Basin along an extension of the Ashizuri transect (Fig. 2). Because of spot coring by DSDP, the age constraints at that site are insufficient to establish reliable upper and lower boundaries to the facies, but microfossils are indicative of latemiddle Miocene to early Pliocene deposition (Karig et al., 1975). The age-depth model at ODP Site 1177 is considerably better, and those sand deposits range in age from 15.6 Ma to 6.9 Ma (Fig. 7). Marsaglia et al. (1992) reported mean Q-F-L values (total quartz, total feldspar, total lithic) of Q-44, F-26, L-30 for seven samples from Site 297, similar to the mean values reported by Fergusson (2003) for seven samples from Site 1177: Q-48, F-25, L-27. The petrofacies data are broadly indicative of a generic dissected-arc to recycled-orogen provenance, as defined by Dickinson et al. (1983).

The lower portion of the volcanic turbidite facies also matches an interval with strong acoustic-impedance contrasts. Pickering et al. (2013) named that sand body the Daiichi Zenisu
Fan. The acoustic interval thins to the south but continues over the crest of Kashinosaki Knoll (Fig. 9). Rates of sedimentation within this interval averaged $6.3 \mathrm{~cm} / \mathrm{k}$.y. at Site C0011 (Fig. 4) and $5.2 \mathrm{~cm} / \mathrm{k} . y$. at Site C0012 (Fig. 5). Blocky log response and discontinuous reflection geometries are characteristic of submarine channels (Pickering et al., 2013). Some channels measure $10-20 \mathrm{~m}$ in depth and $800-1000 \mathrm{~m}$ in width, similar to the dimensions of many modern and ancient examples (Clark and Pickering, 1996). Coring showed that the basal part of the thickest channel fill contains $\sim 10 \mathrm{~m}$ of disaggregated pieces of volcaniclastic sandstone and bioturbated mudstone, tight to isoclinal folds, thinning and attenuation of bedding, and subhorizontal small-scale faults with a normal (extensional) sense of displacement (Expedition 322 Scientists, 2010a). The inferred masstransport deposits were erosive and probably responsible for channel incision. The map-view orientation of the buried channels remains uncertain; they might be relatively straight channels emanating from the east-northeast (i.e., subparallel to the trend of the trench axis) or sinuous channels coming from the north (Pickering et al., 2013).

The uppermost interval of high-amplitude reflections crossing Kashinosaki Knoll is more continuous and sheet-like in geometry (Fig. 9). Pickering et al. (2013) named that nonchannelized sand body the Daini Zenisu Fan. The correlative coring interval contains distinctive, thick beds of tuffaceous sandstone (Expedition 322 Scientists, 2010a), and the seismic interval can be traced without breaks over the crest of the Kashinosaki basement high. Pickering et al. (2013) interpreted the sand body to be a product of energetic but unconfined sediment gravity flows that prograded into the Shikoku Basin from a source to the north or northeast. Additional indicators of detrital provenance come from a combination of smear-slide petrography and geochemical analyses of the distinctive tuffaceous sandstones (Kutterolf et al., 2014). Those sands probably were transported into deep water by density-graded turbidity currents that formed during or immediately after large volcanic eruptions, perhaps as pyroclastic flows entered the ocean (Schindlbeck et al., 2013). The sandstones of Daini Zenisu Fan are dominated by volcanic-rock fragments and pyroclasts, with lesser amounts of sedimentary-rock and metamorphic-rock fragments, whereas sandstones from Daiichi Zenisu Fan are more enriched in sedimentary and metamorphic lithic grains, suggestive of a mixed volcanic-sedimentary source area (Kutterolf et al., 2014).

To provide broader regional and temporal context for interpretation of the Miocene petrofacies in Shikoku Basin, we summarize results for trench sands deposited in the Nankai Trough. Marsaglia et al. (1992) reported the following averages for DSDP Sites 582 and 583 (Fig. 2): Q-22, F-24, L-54, and Lm-32, Lv-46, Ls-22, Lm-metamorphic lithic, Lv-volcanic lithic, Ls-sedimentary lithic. Averages for Quaternary deposits at Site 1174 are Q-13, F-20, L-67, and Lm-8, Lv-59, Ls-33 (Fergusson, 2003). Detrital modes for accreted Quaternary sands at IODP Site C0006 (Fig. 2) average Q-50, F-21, L-29, and Lm-51, Lv-20, Ls-29 (Usman et al., 2014). The average modes 

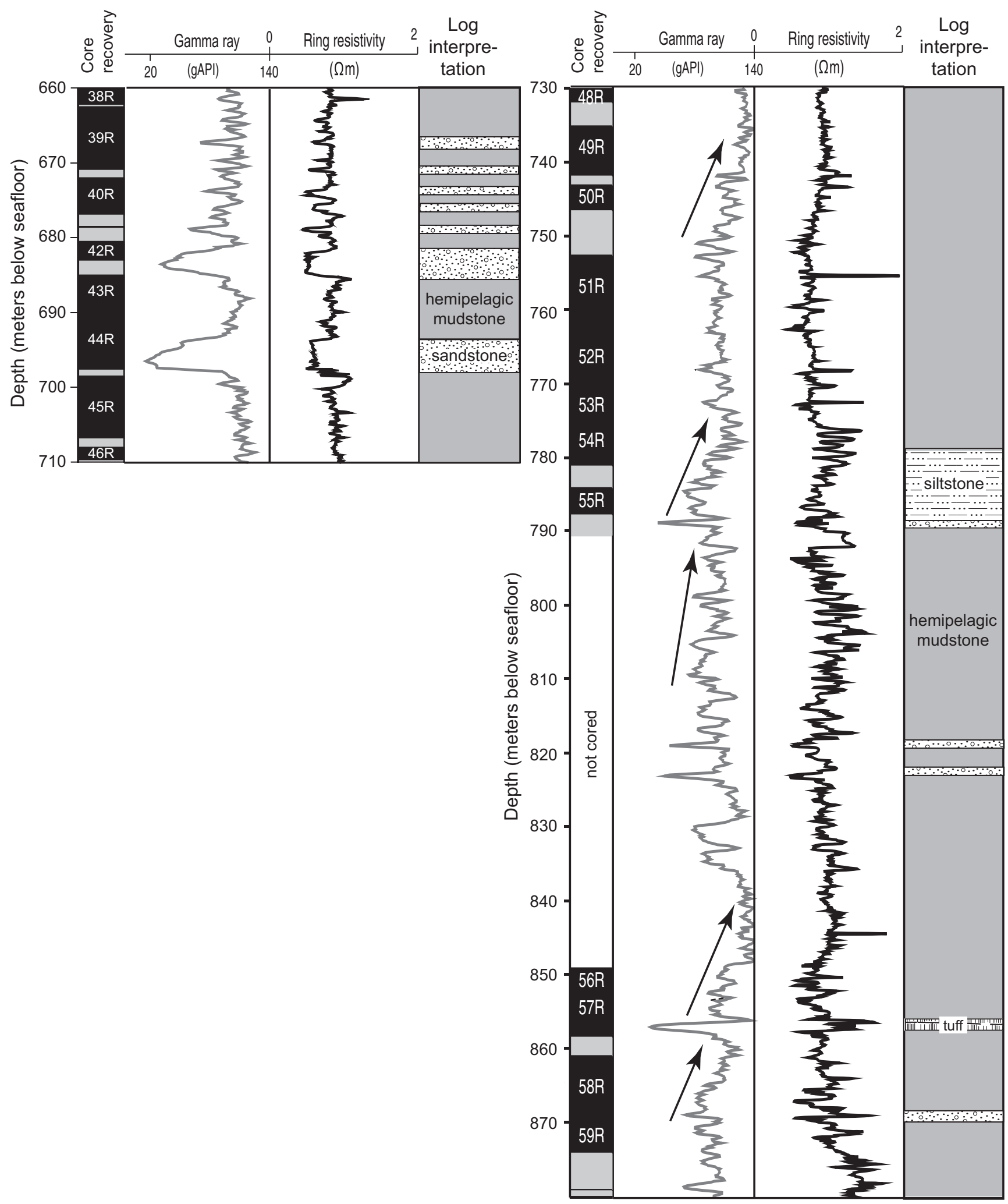

Figure 10. Logging while drilling data from the mixed turbidite facies at Integrated Ocean Drilling Program (IODP) Site C0011. Log interpretations are from Expedition 322 Scientists (2010b). Arrows are indicative of upward-fining cycles. Note the intervals of poor core recovery (black) and intervals that were not cored because of a deteriorating drill bit. 
for accreted Pliocene-Pleistocene sands (Sites 1175 and 1176) are Q-64, F-14, L-22, and Lm-10, Lv-16, Ls-74, whereas late Miocene accreted deposits at Site 1178 (Fig. 2) yield averages of Q-29, F-17, L-54, and Lm-3, Lv-4, Ls-93 (Fergusson, 2003). The apparent spatial trend from the northeast (more quartzose) to southwest end of the trench (more lithic-rich) probably reflects a difference in the competition between long-distance axial transport by sediment gravity flows (moving down the gradient of the trench floor) and transverse input to the trench through large submarine canyons that are incised into the landward trench slope across the margin's strike length (e.g., Soh and Tokuyama, 2002; Underwood et al., 2003b; Kawamura et al., 2009; Yoshikawa and Nemoto, 2010; Usman et al., 2014; Buchs et al., 2015). In addition, the proportion of volcaniclastic sand transported to the trench gradually increased through time, probably as an indirect response to acceleration of nearby arc-related volcanism (e.g., Mahony et al., 2016).

\section{DEPOSITION OF HEMIPELAGIC MUD IN THE SHIKOKU BASIN}

\section{General Considerations}

The sand component of the total sediment budget for Shikoku Basin provides an incomplete record of the basin's evolution. For a more holistic view, we also consider the hemipelagic influx. Reconstructions of paleodispersal systems for fine-grained suspended sediment are more complicated than for bottom-seeking sediment gravity flows, however, because a larger number of physical and biological processes contribute: wind-driven ocean surface currents, thermohaline bottom currents, eolian transport, resedimentation by the full spectrum of sediment gravity flow processes, glacial-marine transport (at high latitudes), biological production, and particle aggregation and resuspension by benthos (e.g., Gorsline, 1984; Gingele et al., 2001; Phillips et al., 2014). The local balance among all of those mechanisms should be expected to change over time in response to global climate cycles, local/regional tectonics, the configuration of landmasses and fluvial drainage systems, and transformations of bathymetry by erosion and sediment accumulation. As burial depths increase, the possibility also exists for the primary mineral assemblages to be obscured by authigenic or diagenetic overprints. Next, we summarize one important aspect of hemipelagic sedimentation in the Shikoku Basin: the detrital clay mineral assemblages, as documented by X-ray diffraction (XRD).

Numerous studies have demonstrated the importance of environmental and geologic factors in modulating compositional changes in clay mineral assemblages. The ratio of chlorite-to-kaolinite, for example, decreases systematically from higher latitudes toward the tropics because of an intensification of chemical weathering at the expense of physical weathering (Biscaye, 1965; Petschick et al., 1996). Consequently, temporal changes in those mineral abundances can be treated as a proxy for paleoclimate (Thiry, 2000). Mechanical weathering of poly- mictic sources, which are typical of subduction complexes and collisional orogenic belts, usually produces clay mineral assemblages (at midlatitudes) that are enriched in detrital illite and chlorite, with modest amounts of smectite and kaolinite (Griggs and Hein, 1980; Karlin, 1980; Naidu and Mowatt, 1983; Hathon and Underwood, 1991). Expandable clay minerals of the smectite group are widely regarded as tracers for meteoric weathering and pedogenesis of volcanic sources (Karlin, 1980; Parra et al., 1985, 1986; Chamley, 1989; Petschick et al., 1996; Fagel et al., 2001). Fluctuations in the rate and volume of volcanic eruptions (due, for example, to changing subduction rates or angles) can lead to commensurate shifts in the weathering and delivery of smectite from volcanic-rich watersheds. The competition among chemical weathering, mechanical weathering, and source-rock composition often oscillates on both local and regional scales in response to global climate change (glacial-interglacial cycles) and microclimate. Eustatic changes in sea level, moreover, are sometimes responsible for shifting the spatial distribution of source rocks within a given watershed, from exposure of soils to atmospheric processes on an emergent shelf to times when the shelf is flooded by seawater (Steinke et al., 2008).

\section{Clay Mineral Assemblages in Shikoku Basin}

Earlier XRD studies provided some insights into how detrital clay mineral assemblages in the Nankai Trough and Shikoku Basin changed over time (Cook et al., 1975; Chamley, 1980; Chamley et al., 1986; Underwood et al., 1993a, 1993b). Those workers documented a preponderance of detrital illite and chlorite within the Quaternary trench-wedge deposits, suggestive of a provenance dominated by exposures of sedimentary and metasedimentary strata. In contrast, hemipelagic muds within the central Shikoku Basin (DSDP Sites 297, 442, 443, and 444) display progressive enrichments of smectite as burial depths increase (Cook et al., 1975; Chamley, 1980). At Site 808 (Fig. 2), smectite increases within the upper Shikoku Basin deposits (relative to the overlying trench-wedge), but for older strata, Underwood and Pickering (1996) were unable to discriminate with confidence between the effects of temporal changes in detrital sources (and/or transport paths) and temperature-driven reactions of ash-to-smectite and smectite-to-illite diagenesis. Burial temperatures were high enough at Site 808 to increase the proportion of illite in illite/smectite (I/S) mixed-layer clays to $~ 70 \%$ at a depth of 1200 mbsf (Underwood and Pickering, 1996; Masuda et al., 1996, 2001).

Subsequent XRD results from Sites 1173 and 1174 (Steurer and Underwood, 2003) verified the overprint of smectite-to-illite diagenesis. The overprint at Site 1173 occurs outboard of the subduction front and starts at a depth of $\sim 400 \mathrm{mbsf}$ (Fig. 6). The overprint affects strata at Site 1174 (Fig. 2) to an even greater extent (Steurer and Underwood, 2003). Presubduction illitization along the Muroto transect has been attributed to anomalously high heat flow (Yamano et al., 2003; Harris et al., 2013), together with rapid burial of Shikoku Basin sediments beneath the Nankai 
trench wedge (Underwood, 2007; Saffer et al., 2008; Saffer and McKiernan, 2009).

Along the Ashizuri transect, Steurer and Underwood (2003) discovered that percentages of smectite at Site 1177 are substantially higher than at Site 1173, particularly within Miocene mudstones now assigned to the Kyushu Fan. Relative percentages of smectite are generally $>40 \mathrm{wt} \%$ of the bulk mudstone, but the values decrease to $<15 \mathrm{wt} \%$ in the overlying hemipelagicpyroclastic facies (Fig. 7). Data from DSDP Site 297 likewise show large increases in the abundance of smectite (Underwood et al., 2003a). Heat flow near Site 1177 is significantly lower than along the trend of the Kinan seamounts (Harris et al., 2013), and modeling of smectite-to-illite reaction progress demonstrated that burial temperatures were not warm enough at Site 1177 to initiate the I/S reaction (Steurer and Underwood, 2003). Instead, those smectite-rich assemblages retain the primary compositional fingerprint of a largely volcanic source prior to ca. $10 \mathrm{Ma}$. The plots of XRD data for Sites 1173 and 1177 both show gradual decreases in detrital smectite through the uppermost hemipelagic facies and the overlying hemipelagic-pyroclastic facies (Figs. 6 and 7). Measurements of cation exchange capacity provide complementary evidence for up-section decreases in smectite (Henry and Bourlange, 2004).

Underwood and Guo $(2013,2017)$ documented the composition of clay mineral assemblages at Sites C0011 and C0012. They found no empirical evidence at either site for a diagenetic overprint (Underwood and Guo, 2013). Guo (2012) also ran numerical simulations to test for I/S reaction progress under the documented thermal conditions (Hamamoto et al., 2011; Harris et al., 2013; Marcaillou et al., 2012). Burial temperatures seaward of the trench were insufficient to initiate such reactions, so the record of the detrital influx remains pristine.

To illustrate further how and when the clay minerals changed during the last 15 m.y. of sedimentation in the Shikoku Basin, we interpolated the age at each sample's depth on its respective linear segment of the age-depth model (Figs. 4 and 5). The trends for age versus smectite (relative wt $\%$ of the bulk sediment) are plotted in Figure 11. Detrital smectite dominates in sediments older than $10 \mathrm{Ma}$, with values at both Sites C0011 and C0012 typically ranging from 40 to $60 \mathrm{wt} \%$. Such values are similar to the results for coeval samples at Site 1177 (Fig. 7) and Site 297 (Underwood et al., 2003a). At all four sites, we see considerable amounts of compositional scatter among the older Miocene strata, but the temporal trend is straightforward: Concentrations of smectite decreased systematically through time. The statistical fit is particularly striking over the last $10 \mathrm{~m}$.y. (Figs. $11 \mathrm{C}$ and 11D). Linear regression yields correlation coefficients over that time span of $r=0.78$ (Site C0011) and $r=0.70$ (Site C0012). We attribute the slightly weaker statistical fit at $\mathrm{C} 0012$ to time gaps in the stratigraphy created by slumping and unconformities (Expedition 322 Scientists, 2010b; Expedition 333 Scientists, 2012c). To summarize, over the last $10 \mathrm{~m}$.y. of sedimentation in the Shikoku Basin, the average concentration of smectite in bulk mudstones decreased by $\sim 3 \mathrm{wt} \%$ for each 1 m.y. decrease in age (Fig. 11).

\section{DISCUSSION}

\section{Provenance and Dispersal of Sand Bodies in Shikoku Basin}

The plate-tectonic reconstructions of Mahony et al. (2011), Hall (2002, 2012), Seton et al. (2012), and Wu et al. (2016) all place the northern edge of Shikoku Basin adjacent to the East China Sea prior to rapid opening of the Sea of Japan from $18 \mathrm{Ma}$ to $15 \mathrm{Ma}$. If those reconstructions are correct, then the Kyushu Fan phase of sand influx to the Shikoku Basin probably passed through a network of submarine canyons that cut into the Chinese continental margin (i.e., to the west of the rotating crustal blocks of Kyushu; Fig. 12A). Analogous submarine canyons exist today along the northern margin of Okinawa Trough (Zhao et al., 2008; Oiwane et al., 2011; Wu et al., 2014). We suggest that comparable systems incised and remained active during incipient subduction of the Philippine Sea plate, extending sedimentsupply routes across what is now the Ryukyu arc-trench system (Fig. 12A). As further evidence for that dispersal route, Clift et al. (2013) presented compelling data for a match in thermochronology between zircon and apatite grains from Site 1177 and grains from the Yangtze River. If their correlation is correct, then it implies extension of a Miocene catchment all the way into the craton of central China. In addition, basin inversion affected the central and northern East China Sea during the late Miocene. The entire Tertiary succession, nearly $10 \mathrm{~km}$ in thickness, underwent inversion and erosion of up to $1.6 \mathrm{~km}$ of sedimentary strata (Yang et al., 2011). We suggest those erosional events also contributed significant volumes of sediment to the Shikoku Basin during the middle to late Miocene.

Clift et al. (2013) referred to the Miocene sand deposits at Site 1177 as "trench fill," which is incorrect, and they neglected to restore paleopositions of the turbidites to locations far south of the present-day trench. When submarine fan sedimentation started (ca. 15.6 Ma), subduction of the Philippine Sea plate had just commenced (Hibbard and Karig, 1990; Wu et al., 2016). The northern edge of Kyushu-Palau Ridge was still located south of the newly developed subduction front, not yet in a position to block turbidity currents coming from the northwest. The fledgling trench, moreover, did not provide a deep enough obstruction to block or deflect transport of sediment gravity flows from the northwest. The axial ridge of Shikoku Basin (i.e., Kinan seamount chain) ceased spreading at ca. $15 \mathrm{Ma}$. Its elevation stood in the way of most flows moving toward the eastern half of the basin. To get past that basement high, larger flows either funneled between the Kinan seamounts (e.g., Moore et al., 2001b) or circumvented the northernmost edge of the ridge (Fig. 12A). Kyushu Fan sedimentation ceased along the Kumano transect area at 12.8-12.2 Ma (Figs. 4 and 5). In our interpretation, that cutoff marks the arrival of elevated basement highs (Kinan seamounts) at the proto-Nankai subduction front, thereby blocking access of gravity flows to the east side of the basin. In addition, oblique to strike-slip motion along the margin (e.g., $\mathrm{Wu}$ et al., 2016) may have shifted the east side of Shikoku Basin 

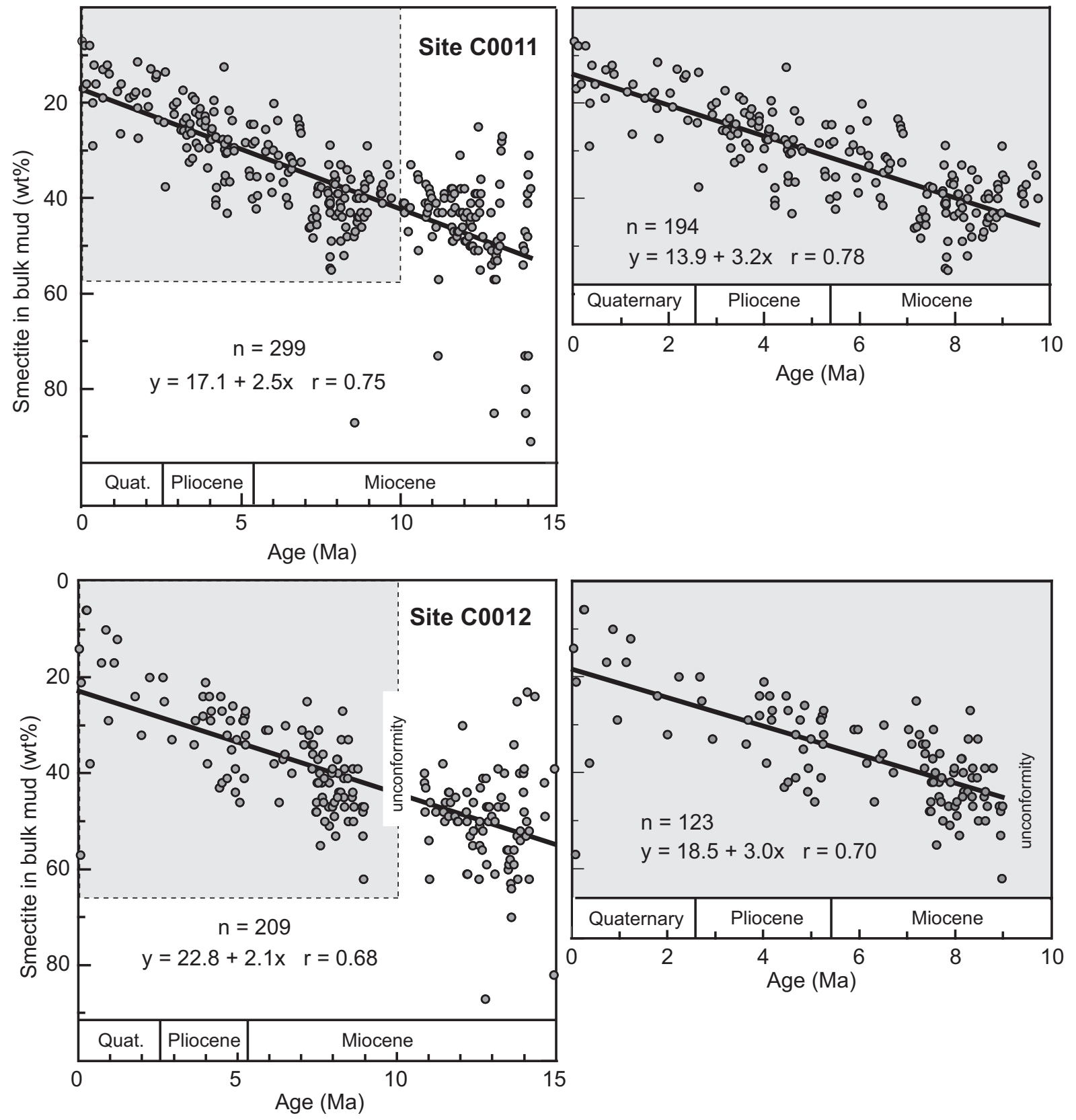

Figure 11. Temporal changes in relative abundance of smectite in hemipelagic deposits at Integrated Ocean Drilling Program (IODP) Sites C0011 and C0012, expressed as wt\% of the bulk sediment. See Figures 4 and 5 for age-depth models and compositional trends with depth. X-ray diffraction data are from Underwood and Guo (2013, 2017). Enlarged plots highlight linear regression statistics for depositional ages of $10 \mathrm{Ma}$ to Holocene $(n=$ number in population, $r=$ correlation coefficient). 

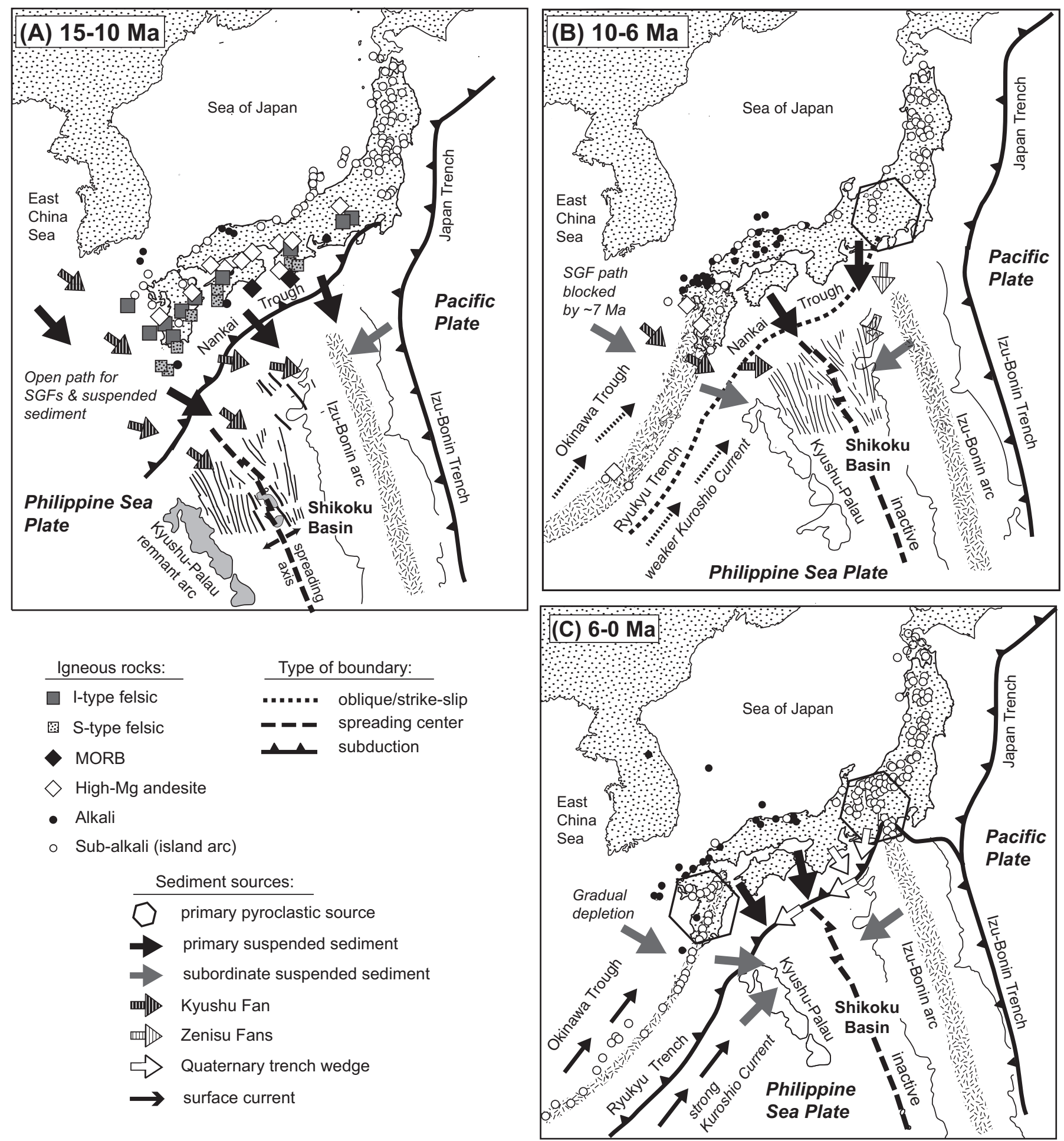

Figure 12. Simplified paleogeographic reconstructions of the northern Shikoku Basin and surrounding regions during three stages of tectonic evolution: (A) 15-10 Ma, (B) 10-6 Ma, and (C) 6-0 Ma. Each map highlights our interpretations of major sediment sources and dispersal paths for sediment gravity flows (SGFs), suspended hemipelagic sediments, and pyroclastic deposits. Distributions of igneous rocks across the Japanese Islands are from Kimura et al. (2005). The Japanese Islands are held fixed relative to present-day coordinates and shorelines to provide a static geographic reference frame for onland magmatism. These reconstructions do not include rigorous restorations of rotation and subduction of the Philippine Sea plate and allow for uncertainties in position and migration of the triple junction joining the Pacific, Philippine Sea, and Eurasia plates. In addition, outlines of Kyushu-Palau Ridge, Izu-Bonin arc, and Kinan seamount chain correspond to present-day bathymetry and are not meant to show portions along their strike consumed by subduction. MORB — mid-ocean-ridge basalt. 
progressively farther from the basin's entry point for the turbidity currents (Fig. 12B).

In our reconstruction, Kyushu Fan remained active on the west side of Shikoku Basin until 6.9 Ma (Fig. 12B), extending into the phase of highly oblique subduction to sinistral slip (ca. 10-6 Ma) along the margin (Kimura et al., 2005; Wu et al., 2016). Evidently, bathymetric architecture along the protoNankai margin was not configured to block or trap sediment gravity flows landward of Shikoku Basin. In some such systems, vertical offsets along strike-slip faults result in sediment ponding (fill-and-spill) within a ridge-and-trough topography (e.g., Teng and Gorsline, 1989; Normark et al., 2009). It is equally common, however, for submarine canyon-fan systems to cut across the entire width of a transform margin (McHugh et al., 1998; Fildani and Normark, 2004; Goldfinger et al., 2007; Mountjoy et al., 2009; Paull et al., 2011). Accordingly, we suggest that the changing sense of plate motion along the proto-Nankai margin, by itself, did not cause termination of sand influx to the Shikoku Basin. Instead, the final demise of Kyushu Fan, at ca. 7 Ma, was more likely a response to two extrabasinal events: subsidence in the incipient Okinawa Trough, and magmatic growth of Ryukyu arc volcanoes to elevated positions near or above sea level. After that island-arc topography materialized, subsequent sediment gravity flows from the East China Sea were trapped behind the Ryukyu Islands (Fig. 12C). In addition, subsequent acceleration of near-orthogonal convergence at ca. 6-5 Ma should have resulted in increased shortening and development of more pronounced topographic relief in the Nankai Trough. We would expect flows entering the deeper trench to be routed parallel to its axis rather than spilling over into the Shikoku Basin.

The topography and fluvial drainage systems that supplied sand to the younger Zenisu fans between 9.2 Ma and 7.6 Ma were probably closer to what we see in the present geography of the Japanese margin. The Daiichi and Daini Zenisu sand bodies were deposited during the oblique-subduction to sinistral-slip phase of plate motion along the proto-Nankai Trough (Kimura et al., 2005; Wu et al., 2016). Neither the Daiichi Zenisu nor the Daini Zenisu depositional systems reached the western side of Shikoku Basin, which indicates that their sand sources were probably located to the east or northeast (Fig. 12B). The sand composition of both fans is consistent with a mixed provenance that contained an abundance of sedimentary, metasedimentary, and volcanic source rocks (Pickering et al., 2013; Kutterolf et al., 2014). Those lithologies are currently exposed in the Izu-Honshu collision zone (e.g., Toriumi and Arai, 1989; Soh et al., 1991, 1998; Takahashi and Saito, 1997), so our interpretation connects the Zenisu fans to a similar source.

The channels of Daiichi Zenisu Fan display length and depth scales similar to the Quaternary axial channel in the Nankai Trough (Shimamura, 1989). It could be argued that such dimensions (hundreds of meters wide by several tens of meters deep) preclude derivation of sediment gravity flows from small watersheds of the Izu-Bonin islands; when compared to paleowatersheds of central Honshu, the islands might seem less likely to feed point sources of fluvial discharge large enough to erode and sustain a deep-water channel-levee complex. To counter that argument, we note that large erosional features are common along the modern Izu-Bonin-Mariana system (e.g., Chadwick et al., 2005; Gardner, 2010). Zenisu submarine canyon and channel system, in particular, funnels turbidity currents and debris flows into the Zenisu Trough on the southeast side of the uplifted Zenisu Ridge (Wu et al., 2005). The head of Zenisu Canyon is incised into the Izu arc at a water depth of $1000 \mathrm{~m}$, and the channel's thalweg on the basin floor is 40-50 m deep and 500-1000 m wide. Additional coring would be needed to confirm how far those Quaternary turbidites extend into the northeast corner of Shikoku Basin (i.e., toward Kashinosaki Knoll). In our interpretation, routing during the late Miocene passed through features similar to Zenisu Canyon.

The Daini Zenisu Fan contains distinctive tuffaceous sandstones with large clasts of reworked pumice. Kutterolf et al. (2014) compared their major-element concentrations, trace-element ratios, and $\mathrm{Sr}-\mathrm{Nd}-\mathrm{Pb}$ isotopes with those of several potential sources for volcanic detritus (e.g., Ryukyu arc, northern Honshu, southern Honshu, Izu-Bonin arc and rear-arc, northern Kyushu); they found a paleo-Honshu source to be the best geochemical match. Honshu arc volcanoes during that time extended from the Izu-Honshu collision zone northeast into northern Honshu (Fig. 12B; Kimura et al., 2005). The sheet-like geometry of Daini Zenisu Fan indicates that the associated sediment gravity flows were able to move unimpeded for hundreds of kilometers from the collision zone toward the center of Shikoku Basin (Fig. 12B).

Transformation of the Nankai Trough into a deeper and narrower bathymetric feature, with prominent slopes on the landward and seaward sides, probably started ca. $6 \mathrm{Ma}$ in response to the renewal of near-orthogonal subduction of the Philippine Sea plate (e.g., Kamata and Kodama, 1994; Wu et al., 2016). Development of the trench's seaward slope was responsible for funneling most of the subsequent Pliocene and Quaternary sediment gravity flows down the axis of the trench, toward the southwest, rather than allowing spillover into Shikoku Basin (Fig. 12C). Local exceptions to that norm of axial transport can be found on the northeast side of Kashinosaki Knoll. Seismic-reflection profiles there display evidence for escape of trench turbidites and burial of upper Shikoku Basin sediments (Ike et al., 2008a) well seaward of the usual position of trench-wedge onlap, which is 7-21 km from the landward base-of-slope (Mountney and Westbrook, 1996). When viewed as a whole, however, axial flows appear to have dominated during the Quaternary.

Most previous workers have argued that sand-rich deposits in the present-day trench wedge originated mostly from the IzuHonshu collision zone (De Rosa et al., 1986; Taira and Niitsuma, 1986; Marsaglia et al., 1992; Underwood et al., 1993a; Fergusson, 2003; Underwood and Fergusson, 2005; Usman et al., 2014). Clift et al. (2013) provided a contrary and provocative interpretation in which dispersal and along-strike transport of sediment from the collision zone have been limited throughout the margin's history, with little or no effect on trench-floor sedimentation off- 
shore Shikoku and the Kii Peninsula; they further claimed that no sediment from the collision zone can be found offshore Kyushu, a distance of $350-500 \mathrm{~km}$ along the strike of the margin. Those assertions may be correct for some of the older (Miocene to early Pleistocene) sediment gravity flow deposits that were offscraped into the accretionary prism at Sites 1178 and 1176 (see also Fergusson, 2003; Underwood and Fergusson, 2005), but we refute the interpretation for the Quaternary trench wedge (Fig. 12C).

Beyond the cogent petrographic arguments of others (e.g., Marsaglia et al., 1992; Fergusson, 2003), we reiterate the following lines of evidence in support of a long-lasting detrital source in the Izu-Honshu collision zone and sustained, long-distance axial transport down the trench: (1) The gradient of the Nankai trench floor dips to the southwest, which favors sediment gravity flows moving in that direction; (2) a large submarine canyon (Suruga Trough) has been deeply incised into the northeastern end of Nankai Trough; (3) three subaqueous slope-type fan deltas have prograded from the head of Suruga Trough, all aligned with the mouths of high-gradient rivers (Soh et al., 1995); (4) frequent storm-induced sediment-transport events flush sediment from the head of Suruga Trough, even during the Holocene highstand of sea level (Yoshikawa and Nemoto, 2010); (5) a second large submarine canyon (Tenryu Canyon) was incised immediately seaward of the Tenryu River mouth, resulting in exposure of metamorphosed Miocene accretionary prism along the deep-water canyon walls (Kawamura et al., 2009); (6) erosion in Tenryu Canyon was rejuvenated following the collision of the proto-Zenisu Ridge with the accretionary prism (Soh and Tokuyama, 2002); (7) highresolution bathymetric records highlight a prominent axial channel on the Nankai trench floor (see Fig. 2), which begins at a point source at the mouth of the Fuji River and extends to a position offshore the Kii Peninsula (Shimamura, 1989); (8) the Tenryu Fan prograded onto the trench floor at the mouth of Tenryu Canyon, causing southward deflection of the axial channel (Soh et al., 1991); (9) deeper seismic-reflection character (i.e., highamplitude reflections) shows temporal continuity of axial-channel migration, extending back at least into the late Pleistocene (Shimamura, 1989); (10) a 7 m.y. history of rapid uplift exists within the inferred Izu-Honshu source area (e.g., Tanzawa Mountains), characterized by high rates denudation (up to $2 \mathrm{~mm} / \mathrm{yr}$ ) and exhumation of tonalites from midcrustal depths (Yamada and Tagami, 2008; Tani et al., 2010); (11) bedrock uplift rates in the Kiso Range of central Japan equal 3-6 mm/yr, with denudation rates of 1-4 mm/yr (Sueoka et al., 2012); (12) paleocurrent evidence from DSDP Site 808 is consistent with reflection or deflection of turbidity currents off the seaward slope (Pickering et al., 1992); and (13) the magnetic fabric in distal trench turbidites (Sites 582 and 583) is oriented parallel to the axis of the trench (Taira and Niitsuma, 1986).

\section{Provenance and Dispersal of Hemipelagic Muds}

XRD data from Sites C0011 and C0012 (Underwood and Guo, 2013, 2017) provide a robust record of the temporal shifts in clay mineral assemblages, enhancing what Underwood and Fergusson (2005) had described previously for the regional Nankai-Shikoku system. Underwood and Fergusson (2005) recognized that fine-grained suspended sediments had been eroded and transported from multiple sources, and that competition among those sources and dispersal routes have changed gradually over time. They attributed the gradual depletion of detrital smectite, with commensurate increases in illite and chlorite, to four factors: (1) intensification of the NE-directed Kuroshio Current after closure of the Central America seaway at ca. $3 \mathrm{Ma}$ (Molina-Cruz, 1997; Tsuchi, 1997); (2) strengthening of ocean bottom currents at ca. $6 \mathrm{Ma}$, in response to buildup of Antarctic ice and enhanced circulation of Antarctic bottom water (Lee and Ogawa, 1998); (3) shifts in centers of active volcanism, as well localities with widespread exposures of weathered volcanic rock (Kamata and Kodama, 1994; Cambray et al., 1995); and (4) progressive uplift and erosion of accreted sedimentary and metasedimentary rocks across the Outer Zone of Japan (Taira et al., 1988; Hasebe et al., 1993, 1997; Nakajima, 1997). Parallel trends in clay mineral assemblages in the Sea of Japan have been linked to the effects of a strengthening Tsushima Current (Fagel et al., 1992). We can now extend the record of hemipelagic input to Shikoku Basin back to $15 \mathrm{Ma}$ (Fig. 11). Refinements to our interpretations are supported by improved reconstructions of regional plate-tectonic history (e.g., Hall, 2002; Mahony et al., 2011; Wu et al., 2016), better mapping and dating of time-space patterns for magma bodies (e.g., Kimura et al., 2005; G. Kimura et al., 2014), expanded records of regional and local denudation history (e.g., Hasebe and Hoshino, 2003; Hasebe and Watanabe, 2004; Yamada and Tagami, 2008), and consideration of some new geochemical indicators of detrital provenance for the coeval sand deposits in Shikoku Basin (e.g., Clift et al., 2013; Kutterolf et al., 2014).

As discussed previously, the likelihood of having sandy sediment gravity flows funneled from the East China Sea into the Shikoku Basin during Kyushu Fan deposition is strong. If the sand and silt components of the basin's sediment budget followed that dispersal route from ca. $16 \mathrm{Ma}$ to ca. $7 \mathrm{Ma}$, then some clay-size suspended sediment must have tracked the same path (Figs. 12A and 12B). Termination of that route for bottom-seeking sediment gravity flows, however, did not necessarily result in a permanent cutoff of suspended sediment, as some exchange of surface water would still be possible through gaps between the volcanic islands of the Ryukyu arc, especially during highstands of sea level (Fig. 12C). During lowstands, a continuous land bridge evidently blocked such exchanges of water masses (Ujiié and Ujiié, 1999).

One way to constrain the compositional fingerprint of the East China Sea is by measuring clay mineral abundances of near-surface muds in Okinawa Trough. Those muddy sediments are enriched in illite $(>50 \%)$ with relatively low percentages of smectite, typically $<30 \%$ of the total clay (Dou et al., 2010; Xu et al., 2014; Wang et al., 2015). Diekmann et al. (2008) showed comparable dominance by detrital illite during the Quaternary at ODP Site 1202, which is located on the western edge of southern 
Okinawa Trough. If we assume that bulk-sediment compositions from kindred sources were similar during the Miocene, then pulses of suspended sediment emanating from mainland China (via the East China Sea) and/or farther west from Taiwan should have been distinctly illite-rich. Instead, we find high concentrations of smectite in Miocene strata within the Shikoku Basin (Fig. 11). Thus, the main route of suspended sediment during the Miocene was probably not through the East China Sea.

The anomalous near-trench magmatism that swept across the Outer Zone of Japan from ca. $16 \mathrm{Ma}$ to $12 \mathrm{Ma}$ (Fig. 12A; Kimura et al., 2005; G. Kimura et al., 2014) left regionally extensive ignimbrite deposits from felsic caldera eruptions (e.g., Danhara et al., 2007; Iwano et al., 2007; Miura and Wada, 2007). Apatite fission-track ages are indicative of rapid cooling, uplift, and exhumation of the associated granitic rocks (Hasebe and Hoshino, 2003). The Izu-Honshu collision zone followed a similar pattern, with rapid exhumation bringing tonalites to the surface from midcrustal $(7-12 \mathrm{~km})$ depths (Yamada and Tagami, 2008). Chemical weathering of the Miocene ignimbrites (which contained abundant, chemically unstable volcanic glass) should have produced soils with high concentrations of smectite. We suggest that $15 \mathrm{~m} . \mathrm{y}$. of progressive denudation, after those eruptions ceased, stripped away the weathered volcanic cover and gradually exposed more of the deeper-seated intrusions and surrounding country rocks (e.g., Shimanto belt). The main cause of gradual smectite depletion within the Shikoku Basin was that gradual change in the balance between volcanic and sedimentary/ plutonic source rocks.

Saitoh et al. (2015) used Sr-Nd-Pb isotope compositions of upper Shikoku Basin sediments (i.e., the hemipelagic-pyroclastic facies) to define a mixing trend over the past 7 m.y. Mixing occurred between two sources: the East China Sea source and a Japan margin source (see also Dou et al., 2012). Their data show progressive decreases in the influx of sediment from China over time, especially between 4.4 Ma and 2.9 Ma. Those decreases in sediment transport from the East China Sea may have been enhanced by intensification of the Kuroshio Current (Fig. 12C), which now directs surface water flow into Okinawa Trough. However, changes in the paleoposition of depositional sites relative to the core of the current also need to be considered (Saitoh et al., 2015). On the other hand, we suggest that the mixing trend of Saitoh et al. (2015) should have been accompanied by contemporaneous decreases in the proportion of detrital illite (i.e., from 4.4 Ma to present); instead, we see the opposite trend in XRD results from sites across the entire Nankai-Shikoku system (Fig. 11). We therefore agree with the suggestion for increasing dominance of suspended-sediment influx from the Japan margin since 4.4 Ma (Fig. 12C), but that increase must have been accompanied by gradual changes in the proportions of parent rock types within those detrital source areas.

Temporal changes in the proportions of different parent rocks across the Outer Zone of Japan are also supported by fission-track data from the Kii Peninsula, which reveal localized Miocene overprints of paleotemperature with the Cretaceous
Shimanto belt (Hasebe and Watanabe, 2004). The regional effects of Miocene magmatism also raised levels of thermal maturity within Eocene-Miocene parts of the accretionary complex and forearc (Chijiwa, 1988; Underwood et al., 1992). Hasebe et al. (1993) and Hasebe and Hoshino (2003) highlighted local examples of differential uplift along the strike length of the Shimanto belt, with younger (ca. $10 \mathrm{Ma}$ ) cooling ages in the Muroto Peninsula. Hasebe and Tagami (2001) provided additional evidence of differential exhumation across the Shimanto accretionary prism, forced by local episodic events. Thus, even though uplift and weathering trends were not uniform across the Outer Zone of Japan, gradual exposure of those granitic plutons, the surrounding accreted sedimentary rocks, and associated metasedimentary rocks to chemical and physical weathering should have produced a clay mineral assemblage that became progressively more enriched in illite and chlorite.

In our interpretation, the onset of gradual and irreversible smectite depletion in the suspended sediments of Shikoku Basin occurred at ca. 9 Ma (Fig. 11). That phase in geologic history represents the turning point in regional-scale uplift of the Japan margin, when widespread sources of detrital smectite (weathered Miocene ignimbrites) began their decline. Subordinate sources, including a small component of eolian input, complicated the picture. Sporadic delivery of illitic clays from the East China Sea source (Fig. 12B) helps to explain the scatter in percentage of smectite (Fig. 11), especially during Miocene deposition of submarine fans. Similarly, subordinate transport of clays as part of the tuffaceous sediment gravity flows from the Izu-Honshu collision zone (Kutterolf et al., 2014) probably resulted in punctuated increases in detrital smectite coming from the northeast side of the basin (Fig. 12B). In general, however, strengthening of the NE-flowing Kuroshio Current during the late Pliocene and early Pleistocene reinforced the Outer Zone trend by transporting illite-rich mud from Taiwan (Diekmann et al., 2008) and dampened transport of smectite-rich suspended sediment eroded from weathered volcanic islands of the Izu-Bonin chain (Fig. 12C).

\section{Initiation of Pyroclastic Influx to the Shikoku Basin}

The final episode of sedimentation history in the Shikoku Basin for us to consider is the onset of pyroclastic influx (i.e., the base of the hemipelagic-pyroclastic facies). To begin with, we recognize a significant difference between numbers of discrete ash layers recovered at Site C0011 $(n=101)$ versus the numbers at Site C0012 ( $n=47)$. A small part of that discrepancy might be an artifact of incomplete core recovery. Perhaps the air-fall deposits have been thinner, on average, on top of the Kashinosaki bathymetric high; thinner ash beds should have a greater likelihood of being homogenized into the hemipelagic mud by bioturbation. Another contributing factor might be creation of unconformities, from winnowing by enhanced tidal energy, or strong bottom currents and eddies moving over the crest of the knoll (e.g., Turnewitsch et al., 2013; Chen et al., 2015; Pollard and Read, 2015; Read and Pollard, 2015), or by 
removal of parts of the section by mass wasting. The net effect is better preservation of tephra layers on the flanks of the knoll than on the crest.

The base of the hemipelagic-pyroclastic facies is enigmatic because its age changes so dramatically along strike (Fig. 8). The boundary varies from 7.8-7.6 Ma on the northeast side of the basin (Figs. 4 and 5) to 3.3-3.9 Ma on the northwest side (Figs. 6 and 7). Diagenetic overprints may have masked the boundary's original position (i.e., due to alteration of deeper ash layers to smectite-rich bentonites), but that effect is inferred to be relatively minor. We reach that conclusion because the projected borehole temperatures are significantly different at the current depths of the unit boundary: $\sim 40{ }^{\circ} \mathrm{C}$ at Site $1177 ; \sim 63{ }^{\circ} \mathrm{C}$ at Site $1173 ; \sim 33{ }^{\circ} \mathrm{C}$ at $\mathrm{C} 0011 ; \sim 23{ }^{\circ} \mathrm{C}$ at Site $\mathrm{C} 0012$ (Spinelli et al., 2007; Expedition 333 Scientists, 2012b, 2012c; Marcaillou et al., 2012). If the boundary were largely diagenetic, then the temperatures at the base of the unit should be similar at all sites. We suggest, instead, that large shifts in the timing of ash influx from west to east are manifestations of plate-boundary reorganizations, particularly the response of explosive arc activity to the renewal of subduction at ca. $6 \mathrm{Ma}$ (Figs. 12B and 12C). To explore that possibility in more detail, we consider where the prospective eruptive centers near Japan were positioned during accumulation of the hemipelagic-pyroclastic facies.

At the present time, Shikoku Basin is fronted by active volcanoes to the east-northeast (Izu-Bonin arc), to the northnortheast (Honshu arc), and to the west-northwest (Kyushu and Ryukyu arcs). Linking individual ash layers to specific eruptions, therefore, is challenging. Expedition 333 Scientists (2012b, 2012c) recognized four distinctive ash beds that they correlated with named and dated tephra deposits on land, ranging in age from 0.85 to 4.0 Ma (Hayashida et al., 1996; Satoguchi et al., 2005; Nagahashi and Satoguchi, 2007). Of those correlations, two tephra beds can be traced eastward from calderas in central Kyushu to the Boso Peninsula of central Honshu (Kamata et al., 1997), and two eruptions probably originated in central Japan. Volcano-specific sources for all of the remaining pyroclastic deposits remain uncertain, but the Honshu arc in central Japan is a logical candidate, especially for ash deposits on the east side of Shikoku Basin.

Island-arc-type eruptions (subalkalic magmas) have occurred along the Honshu arc of NE Japan for the past 12 m.y. (Kimura et al., 2005). Regional analysis of marine tephras shows that the frequency of eruptions has increased since ca. $8 \mathrm{Ma}$ (Mahony et al., 2016). In addition, the volcanic front has migrated landward ( $\sim 50 \mathrm{~km}$ to the west) during the past $3 \mathrm{~m} . \mathrm{y}$. (Nakamura et al., 2014). Atmospheric transport from volcanoes near the southern end of the Honshu arc, in particular, should have carried ash into the northeastern part of the Shikoku Basin on a regular basis (Fig. 12B); prevailing winds currently blow across Japan toward the southeast during the winter, and the subtropical jet stream is directed toward the east. In addition, central Japan experienced a rich history of extremely large explosive eruptions during the Pliocene and Pleistocene (Yoshikawa et al.,
1996; Nagahashi et al., 2000; Kataoka et al., 2001; Iwaki and Hayashida, 2003). Fourteen distinctive marker tephras have been mapped on land, with thickness contours that project offshore into the northern Philippine Sea; the ages of those tephras range from 4.15 Ma to 1.65 Ma (Tamura et al., 2008). Similarly, uplifted Pliocene-Pleistocene marine deposits exposed on the Boso Peninsula (north side of the Izu-Honshu collision zone) contain more than 250 tephra layers, with ages ranging from 2.1 Ma to 0.7 Ma (Satoguchi, 1995). Given that history, we favor central Japan (southern Honshu arc) as the principal source for ash layers at Sites C0011 and C0012 (Figs. 12B and 12C). That influx has been sustained since ca. 7.8 Ma, largely controlled by subduction of the Pacific plate.

Another potential source of windblown ash is located to the east-northeast of Sites C0011 and C0012 along the Izu-Bonin island arc (Fig. 12). Pyroclastic turbidity currents are another possibility (e.g., Schindlbeck et al., 2013). According to Cambray et al. (1995), the Izu-Bonin system experienced two pulses of explosive activity over the last $5 \mathrm{~m}$.y. Prevailing winds, however, are more likely to have transported ash from those volcanoes into the central Shikoku Basin and northern Parece Vela Basin (e.g., closer to DSDP Sites 442, 443, and 444). We therefore regard the Izu-Bonin source as a subordinate contributor of airborne ash to the northeastern part of Shikoku Basin.

Pyroclastic influx to the northwest side of Shikoku Basin started later, during the Pliocene (Fig. 8). Subduction-related volcanism across Kyushu had ceased during the phase of oblique subduction or sinistral slip (ca. $10 \mathrm{Ma}$ to $6 \mathrm{Ma}$; Fig. 12B). The proto-Nankai boundary at that time probably extended into the Ryukyu arc as a zone of left-lateral transpression (Mahony et al., 2011). Eruptions gradually picked up again on Kyushu from $6 \mathrm{Ma}$ to $2 \mathrm{Ma}$, after the convergence direction for the Philippine Sea plate rotated to the northwest. Reinitiation of magmatism was dominated initially by local basalt flows and development of an andesite lava plateau in the Hohi volcanic zone (Kamata and Kodama, 1994, 1999; Mahony et al., 2011). Scattered stratovolcanoes and monogenetic (rhyolitic) volcanoes also erupted during that phase, with ages that range mostly from 3.8 Ma to $2.2 \mathrm{Ma}$ (Mahony et al., 2011). The current style of large-magnitude explosive caldera eruptions started in earnest at ca. $1.5 \mathrm{Ma}$, coincident with formation of a well-defined, NE-SW-trending volcanic front (Kamata and Kodama, 1999; Maeno and Taniguchi, 2007). Several of those explosions were large enough to create marker beds of tephra that extend into central Japan (Kamata et al., 1997; Kaneko et al., 2007), and two of the named ash beds at Sites C0011 and C0012 have been correlated with Kyushu. It stands to reason, however, that the Kyushu source was more prevalent on the west (proximal) side of Shikoku Basin. We suggest, therefore, that the stratigraphic base of the hemipelagic-pyroclastic facies at Sites 1173 and 1177 coincides with reinitiation of explosive volcanism on Kyushu and the islands along the northwest end of the Ryukyu arc (Fig. 12C). That influx has been sustained since ca. 3.8 Ma, largely controlled by subduction of the Philippine Sea plate. 
Implications for Subduction Processes and Fault-Slip Behavior

Sedimentary strata within the Shikoku Basin are vital to a broader analysis of the regional tectonics because they represent inputs to the Nankai subduction zone. As such, the complexities of lithostratigraphy and sediment composition that we highlight raise a number of important implications for the likely responses of strata to deformation and diagenesis landward of the subduction front. Fundamentally, the subduction zone is not composed of monotonous sediment that is uniform in its physical properties and behavior in all directions. As such, not only did the region's tectonic evolution affect sedimentation, the textural and compositional attributes of those sediments have modulated the margin's tectonic behavior.

One postdepositional consequence is higher concentrations of dispersed volcanic glass and pumice, which have been shown to be a prerequisite for early silica cementation and retention of intervals of anomalously high porosity (Hüpers et al., 2015); those properties and compaction responses exist only within the upper Shikoku Basin (i.e., the hemipelagic-pyroclastic facies). Sediment shear strength is highly sensitive to concentrations of clay-size particles and clay mineralogy; weaker intervals in the stratigraphy often coincide with higher proportions of smectite (Brown et al., 2003; Kopf and Brown, 2003; Saffer and Marone, 2003; Ikari et al., 2007; Ikari and Saffer, 2011). Specifically, samples from the hemipelagic-pyroclastic facies typically yield values of $0.5-0.6$ for residual apparent coefficient of friction, whereas values for older smectite-rich mudstones are close to 0.2 (Ikari et al., 2013). Thus, the weakest intervals entering Nankai Trough are subducting mudstones and bentonites within the lower Shikoku Basin. As noted by Underwood (2007), the stratigraphic position of the frontal décollement does not coincide with unusually high concentrations of smectite; instead, frictional properties are weak throughout most of the Miocene section.

Hydrogeological properties are likewise sensitive to sediment composition and grain size. Following their accretion, the localized submarine-channel deposits of Daiichi Zenisu Fan, as compared with extensive sheet-like sand deposits of the Kyushu Fan, must create totally different three-dimensional migration routes for fluids draining out of or beneath the accretionary prism. The pathways for focused flow through shoestring-shaped sand bodies are more circuitous and unpredictable in three dimensions. Elevated pore pressures (i.e., above hydrostatic) are more likely to develop at lateral pinch-outs of the sheet-like sand bodies, especially where such aquifers are inclined (Yardley and Swarbrick, 2000) or where sediment gravity flow deposits fill basement lows and lap onto the mudstone carapace of adjacent basement highs (Fig. 9A). Overpressures are also likely where successions of low-permeability mudstone retard vertical drainage from underlying sheet sands (e.g., at the boundary between Kyushu Fan deposits and the hemipelagic mud facies). Pore pressures at those terminations of sand may become high enough to favor specific stratigraphic intervals for abnormally low values of effective normal stress, reduced shear strength, and underconsolidation (Underwood, 2007; Saffer and Tobin, 2011). Stratigraphic intervals with diminished shear strength likely act as preferred paths for seaward propagation of the megathrust and/or megasplay fault. The low-velocity zones detected in the hanging wall of the megathrust (e.g., Bangs et al., 2009) could have similar connections to a facies-dependent hydrogeological architecture.

Changes in concentrations of detrital smectite with depth and age also mean that diagenetic fluid production should peak in the lower half of the Shikoku Basin succession, where initial (presubduction) proportions of smectite exceed $50 \mathrm{wt} \%$ of the bulk sediment (Figs. 4 and 5). As burial progresses, dehydration reactions involving smectite to illite will undoubtedly result in consistently larger volumetric contributions of fluid where initial concentrations of smectite are higher (Saffer et al., 2008). Larger volumes of fluid production, therefore, set up a greater potential for overpressured conditions within the footwall to the megathrust (e.g., Colton-Bradley, 1987; Osborn and Swarbrick, 1997; Wangen, 2001). Conversely, the upper stratigraphic intervals of Shikoku Basin (hemipelagic-pyroclastic facies), which are more illite-rich (Figs. 4 and 5) and more likely to be offscraped into the frontal accretionary prism (Screaton et al., 2009b), should produce significantly lower volumes of fluid during clay diagenesis. The temperature structure of the margin also modulates diagenetic fluid production. Heat flow changes along the strike of the Nankai margin largely in response to the age of the subducting plate (Yamano et al., 2003; Spinelli and Underwood, 2005; Harris et al., 2013). Along-strike variations in temperature seaward of the deformation front will exert a first-order control over where the landward (downdip) progression of diagenetic reactions will peak (Saffer et al., 2008), and that variability probably contributes to the different forms of fault-slip behavior along the plate interface and the megasplay (Hyndman et al., 1995; Wang et al., 1995; Oleskevich et al., 1999; Yoshioka and Murakami, 2007). When those disparities in updip and downdip temperature are combined with all of the architectural intricacies that we described for the subduction inputs to Nankai Trough, the timespace patterns for great earthquakes, low-frequency earthquakes, and slow-slip events should be expected to be inhomogeneous (e.g., Hasegawa et al., 2009; Obara, 2009).

\section{SUMMARY AND CONCLUSIONS}

Five decades of scientific ocean drilling have demonstrated that the history of sedimentation within the Shikoku Basin is much more intricate and nuanced than the relatively simple pelagichemipelagic successions found outboard of the Japan and Costa Rica subduction zones. As such, we expect the three-dimensional distributions of sediment shear strength, permeability, diagenetic fluid production, and pore pressure to be more unpredictable and facies-sensitive in the Nankai subduction zone as Shikoku Basin deposits move downdip into the frontal accretionary prism and the footwall to the megathrust. 
Our synthesis of data from sand bodies, hemipelagic mudstones, and pyroclastic deposits demonstrates that sedimentary facies within Shikoku Basin evolved in a punctuated manner, driven by several reorganizations of plate boundaries and changes in plate motions around the basin's margins (e.g., Wu et al., 2016). A factor of somewhat lesser importance for modulating facies architecture was the creation of irregular basement topography during initial stages of back-arc rifting, seafloor spreading, and postspreading construction of seamounts (e.g., Kinan seamount chain, Kashinosaki Knoll). Those basement highs influenced the routing of sand once gravity flows entered the basin by deflecting more sediment into adjacent basement lows.

The Kyushu Fan (Pickering et al., 2013) created sheet-like sand bodies that prograded into Shikoku Basin on both sides of the extinct spreading center during the early to middle Miocene. At the same time, coeval deposits along the Kinan seamount chain (ODP Site 1173) were dominated by hemipelagic settling of fine-grained suspended sediment. The compositions of sediment gravity flow deposits at IODP Sites C0011 and C0012 are consistent with a mixed detrital and pyroclastic provenance. Thermochronology results from Clift et al. (2013) indicate that Miocene sand beds at ODP Site 1177 (west side of Shikoku Basin) were transported across the East China Sea from a protoYangtze River watershed. Kyushu Fan ceased its activity on the east side of the basin at ca. 12.5-12.2 Ma, and that termination event gave way to more than $3 \mathrm{~m}$.y. of uninterrupted hemipelagic deposition. We attribute the earlier east-side termination of Kyushu Fan mostly to blockage of sediment gravity flow transport routes by incipient subduction of the Kinan seamounts along the proto-Nankai Trough. Throughout Shikoku Basin, that phase of Miocene hemipelagic sedimentation was dominated by smectite-rich clay mineral assemblages. Bulk mudstones with ages of $15 \mathrm{Ma}$ to $10 \mathrm{Ma}$ typically contain more than $40 \mathrm{wt} \%$ smectite. The main source of the detrital smectite was subaerial weathering of ignimbrites that erupted across the Outer Zone of Japan shortly after the initiation of subduction of the Philippine Sea plate.

Most plate reconstructions for the Philippine Sea plate (e.g., Mahony et al., 2011; Wu et al., 2016) show sinistral strike-slip or strongly oblique subduction during the late Miocene (10 Ma to $6 \mathrm{Ma}$ ). During that time interval, transport of tuffaceous and volcaniclastic sands was restricted to the east side of Shikoku Basin. Those sediment gravity flow deposits are separated from the older Kyushu Fan deposits by a thick interval of hemipelagic mudstone. The Daiichi Zenisu Fan is channelized, whereas the overlying Daini Zenisu Fan is sheet-like and more "distal" in facies character (Pickering et al., 2013). During both intervals, sediment gravity flows were able to move up the flanks of Kashinosaki Knoll to its crest, and both fan systems thin in the upslope direction. Geochemical and petrographic data from pumice fragments indicate a detrital provenance to the northeast, either in the southern Honshu arc or the Izu-Honshu collision zone (Kutterolf et al., 2014). The modern Zenisu canyon-channel system (Wu et al., 2005) provides us with a convincing analog for that phase of sediment routing. The shift from channelized to sheet-like flows occurred at ca. $8 \mathrm{Ma}$, and influx of volcanic sand from the Izu-Honshu source terminated shortly thereafter (7.8 Ma to 7.6 Ma).

On the west side of the Shikoku Basin, supply routes for sediment gravity flows from the East China Sea remained active up to ca. $7 \mathrm{Ma}$. We suggest that sediment routing to DSDP Site 297 and ODP Site 1177 was finally terminated when bathymetric topography along the Ryukyu arc-trench system grew close enough to sea level to trap subsequent sediment gravity flows behind the volcanic islands. Rifting and opening of the Okinawa Trough back-arc basin contributed to that phase of bathymetric reorganization. Clay mineral assemblages during that period of time began to show a steady decline in the amount of detrital smectite, with reductions of $\sim 3 \mathrm{wt} \%$ smectite for each $1 \mathrm{~m} . \mathrm{y}$. decrease in age. We attribute that change in suspended sediment composition to rapid uplift and denudation of the Outer Zone of Japan. Chemical weathering and physical erosion stripped away the ignimbrites and exposed progressively deeper levels of the Miocene granites and sedimentary rocks of the Shimanto belt accretionary prism.

The bathymetric low that currently defines Nankai Trough as a trench, with prominent slopes on both landward and seaward sides, formed at ca. $6 \mathrm{Ma}$ after renewal of near-orthogonal, northwest-directed subduction of the Philippine Sea plate. The seaward slope of the trench evidently prevented most sediment gravity flows from spilling over into eastern Shikoku Basin. Consequently, the youngest facies in Shikoku Basin is dominated by hemipelagic mudstone with dozens of discrete interbeds of volcanic ash. That phase of pyroclastic influx began ca. $7.8 \mathrm{Ma}$ along the northeastern half of the basin. The main source for that tephra was probably the southern Honshu arc in central Japan, with subordinate influx from the Izu-Bonin islands to the east-northeast. In contrast, onset of substantial pyroclastic influx to the northwest side of Shikoku Basin was delayed until ca. 3.8 Ma. We attribute that difference in age to reintroduction of subductionrelated volcanism across Kyushu and the northeastern Ryukyu Islands. The prominent caldera eruptions on Kyushu commenced at ca. 1.5 Ma. Some of those larger Quaternary explosions created distinctive tephra deposits that extended into central Japan and the northeast side of Shikoku Basin, but their impact on sedimentation was greater on the more proximal northwest side.

Clay mineral assemblages during the Pliocene continued the progressive depletion of detrital smectite and increases in illite and chlorite. $\mathrm{Sr}-\mathrm{Nd}-\mathrm{Pb}$ isotope compositions indicate a mixing trend over the same time interval, with increasing dominance of a Japan-margin source over a source in the East China Sea (Saitoh et al., 2015). Fine-grained sediments in Okinawa Trough are highly enriched in detrital illite, so the temporal shift to dominance by the Japan-margin source must have been accompanied by changes in the rock types exposed to weathering across the Outer Zone of Japan and Izu-Honshu collision zone. We suggest, specifically, that continuation of uplift and denudation resulted in increasingly widespread exposures of Miocene granites, tonalites, forearc-basin deposits, and sedimentary to metasedimentary rocks of the Shimanto belt to weathering and erosion. 
Trench-parallel sediment routing has dominated the Nankai margin during the Quaternary, especially after ca. $2 \mathrm{Ma}$, when collision between the Izu and Honshu volcanic arcs intensified in the main source region to the trench. Except for one local incursion onto the northeast flank of Kashinosaki Knoll (Ike et al., 2008a), we know of no recent examples of sand transport onto the floor of Shikoku Basin. Instead, the lithostratigraphic units of Shikoku Basin are rapidly buried by an upward-thickening and upward-coarsening wedge of trench-floor deposits.

\section{ACKNOWLEDGMENTS}

This research used samples provided by the Integrated Ocean Drilling Program (IODP), the Ocean Drilling Program (ODP), and the Deep Sea Drilling Project (DSDP). We thank all of the crew members, laboratory technicians, and shipboard scientists who assisted during ODP Legs 131 and 190, and IODP Expeditions 322 and 333. J. Steurer and J. Guo contributed significantly to the laboratory effort while students at the University of Missouri. Funding to Underwood was granted by the Consortium for Ocean Leadership, U.S. Science Support Program (task orders T322B58 and T333B58) and the National Science Foundation (grant OCE-07518190). We thank J. Gill, D. Saffer, T. Byrne, and K. Marsaglia for helpful comments and insightful reviews of the manuscript.

\section{REFERENCES CITED}

Acocella, V., Yoshida, T., Yamada, R., and Funiciello, F., 2008, Structural control on late Miocene to Quaternary volcanism in the NE Honshu arc, Japan: Tectonics, v. 27, TC5008, doi:10.1029/2008TC002296.

Amano, K., 1991, Multiple collision tectonics of the South Fossa Magna in central Japan: Modern Geology, v. 15, p. 315-329.

Ashi, J., Lallemant, S., Masago, H., and Expedition 315 Scientists, 2009, Expedition 315 summary, in Kinoshita, M., et al., Proceedings of the Integrated Ocean Drilling Program, Volume 314/315/316: Washington, D.C., Integrated Ocean Drilling Program Management International, Inc., 34 p., doi:10.2204/iodp.proc.314315316.121.2009.

Bangs, N.L.B., Moore, G.F., Gulick, S.P.S., Pangborn, E.M., Tobin, H.J., Kuramoto, S., and Taira, A., 2009, Broad, weak regions of the Nankai megathrust and implications for shallow coseismic slip: Earth and Planetary Science Letters, v. 284, p. 44-49, doi:10.1016/j.eps1.2009.04.026.

Biscaye, P.E., 1965, Mineralogy and sedimentation of Recent deep-sea clay in the Atlantic Ocean and adjacent seas and oceans: Geological Society of America Bulletin, v. 76, p. 803-832, doi:10.1130/0016 -7606(1965)76[803:MASORD]2.0.CO;2.

Bredehoeft, J.D., Devanshir, R.D., and Belitz, K.R., 1988, Lateral fluid flow in a compacting sand-shale sequence: South Caspian Basin: American Association of Petroleum Geologists Bulletin, v. 72, p. 416-424.

Brown, K.M., Saffer, D.M., and Bekins, B.A., 2001, Smectite diagenesis, porewater freshening, and fluid flow at the toe of the Nankai wedge: Earth and Planetary Science Letters, v. 194, p. 97-109, doi:10.1016/S0012 $-821 X(01) 00546-5$.

Brown, K.M., Kopf, A., Underwood, M.B., and Weinberger, J.L., 2003, Compositional and fluid pressure controls on the state of stress on the Nankai subduction thrust: A weak plate boundary: Earth and Planetary Science Letters, v. 214, p. 589-603, doi:10.1016/S0012-821X(03)00388-1.

Buchs, D.M., Cukur, D., Masago, H., and Garbe-Schonberg, D., 2015, Sediment flow routing during formation of forearc basins: Constraints from integrated analysis of detrital pyroxenes and stratigraphy in the Kumano Basin, Japan: Earth and Planetary Science Letters, v. 414, p. 164-175, doi:10.1016/j.eps1.2014.12.046.
Cambray, H., Pubellier, M., Jolivet, L., and Pouclet, A., 1995, Volcanic activity recorded in deep-sea sediments and the geodynamic evolution of western Pacific island arcs, in Taylor, B., and Natland, J., eds., Active Margins and Marginal Basins of the Western Pacific: American Geophysical Union Geophysical Monograph 88, p. 97-124.

Celaya, M., and McCabe, R., 1987, Kinematic model for the opening of the Sea of Japan and bending of the Japanese Islands: Geology, v. 15, p. 53-57, doi:10.1130/0091-7613(1987)15<53:KMFTOO>2.0.CO;2.

Chadwick, W.W., Embley, R.W., Johnson, P.D., Merle, S.G., Ristau, S., and Bobbitt, A., 2005, The submarine flanks of the Anatahan Volcano, commonwealth of the Northern Mariana Islands: Journal of Volcanology, v. 146 , p. $8-25$.

Chamley, H., 1980, Clay sedimentation and paleoenvironment in the Shikoku Basin since the middle Miocene (Deep Sea Drilling Project Leg 58, North Philippine Sea), in Klein, G.deV., Kobayashi, K., et al., Initial Reports of the Deep Sea Drilling Project, Volume 58, Washington, D.C., U.S. Government Printing Office, p. 669-678, doi:10.2973/dsdp.proc.58.118.1980.

Chamley, H., 1989, Clay Sedimentology: New York, Springer-Verlag, 620 p., doi:10.1007/978-3-642-85916-8.

Chamley, H., Cadet, J.P., and Charvet, J., 1986, Nankai Trough and Japan Trench: Late Cenozoic paleoenvironments deduced from clay mineralogic data, in Kagami, H., Karig, D.E., Coulbourn, W.T., et al., Initial Reports of the Deep Sea Drilling Project, Volume 87, Washington, D.C., U.S. Government Printing Office, p. 633-642, doi:10.2973/dsdp proc.87.113.1986.

Chamot-Rooke, N., and Le Pichon, X., 1989, Zenisu Ridge: Mechanical model of formation: Tectonophysics, v. 160, p. 175-193, doi:10.1016/0040-1951 (89)90390-9.

Chamot-Rooke, N., Renard, V., and Le Pichon, X., 1987, Magnetic anomalies in the Shikoku Basin: A new interpretation: Earth and Planetary Science Letters, v. 83, p. 214-228, doi:10.1016/0012-821X(87)90067-7.

Chen, G., Wang, D., Dong, C., Zu, T., Xue, H., Shu, Y., Chu, X., Qi, Y., and Chen, H., 2015, Observed deep energetic eddies by seamount wake: Scientific Reports, v. 5, p. 17416, doi:10.1038/srep17416.

Chijiwa, K., 1988, Post-Shimanto sedimentation and organic metamorphism: An example of the Miocene Kimano Group, Kii Peninsula: Modern Geology, v. 12, p. 363-388.

Clark, J.D., and Pickering, K.T., 1996, Architectural elements and growth patterns of submarine channels: Application to hydrocarbon exploration: American Association of Petroleum Geologists Bulletin, v. 80, p. 194-221.

Clift, P.D., Carter, A., Nicholson, U., and Masago, H., 2013, Zircon and apatite thermochronology of the Nankai Trough accretionary prism and trench, Japan: Sediment transport in an active and collisional margin setting: Tectonics, v. 32, p. 377-395.

Colton-Bradley, V.A.C., 1987, Role of pressure in smectite dehydrationEffects on geopressure and smectite-to-illite transition: American Association of Petroleum Geologists Bulletin, v. 71, p. 1414-1427.

Cook, H.E., Zemmels, I., and Matti, J.C., 1975, X-ray mineralogy data, far western Pacific, Leg 31 Deep Sea Drilling Project, in Karig, D.E., Ingle, J.C., Jr., et al., Initial Reports of the Deep Sea Drilling Project, Volume 31: Washington, D.C., U.S. Government Printing Office, p. 883-895, doi:10.2973/dsdp.proc.31.app.1975

Cukur, D., Horozal, S., Kim, D.C., and Han, H.C., 2011, Seismic stratigraphy and structural analysis of the northern East China Sea Shelf Basin interpreted from multi-channel seismic reflection data and cross-section restoration: Marine and Petroleum Geology, v. 28, p. 1003-1022, doi:10.1016/j.marpetgeo.2011.01.002.

Curtis, D., and Echols, D.J., 1980, Lithofacies of the Shikoku and Parece Vela Basins, in Klein, G.deV., Kobayashi, K., et al., Initial Reports of the Deep Sea Drilling Project, Volume 58: Washington, D.C., U.S. Government Printing Office, p. 701-709.

Danhara, T., Hoshi, H., Iwano, H., Yamashita, T., and Mita, I., 2007, Widespread correlation of middle Miocene tephras in Japan: A possible link between the Kn-1 tuff (Boso Peninsula) and the Muro pyroclastic flow deposit (Kii Peninsula): Journal of the Geological Society of Japan, v. 113 , p. 384-389, doi:10.5575/geosoc.113.384.

De Rosa, R., Zuffa, G.G., Taira, A., and Leggett, J.K., 1986, Petrography of trench sands from the Nankai Trough, southwest Japan: Implications for long-distance turbidite transport: Geological Magazine, v. 123, p. 477486, doi:10.1017/S0016756800035068.

Dickinson, W.R., Beard, L.S., Brakenridge, G.R., Erjavec, J.L., Ferguson, R.C., Inman, K.F., Knepp, R.A., Lindberg, F.A., and Ryberg, P.T., 1983, 
Provenance of North American Phanerozoic sandstones in relation to tectonic setting: Geological Society of America Bulletin, v. 94, p. 222-235, doi:10.1130/0016-7606(1983)94<222:PONAPS $>2.0$.CO;2.

Diekmann, B., Hofmann, J., Henrich, R., Futterer, D.K., Rohl, U., and Wei, K.-Y., 2008, Detrital sediment supply in the southern Okinawa Trough and its relation to sea-level and Kuroshio dynamics during the late Quaternary: Marine Geology, v. 255, p. 83-95, doi:10.1016/j.margeo.2008.08.001

Dolan, J., Beck, C., and Ogawa, Y., 1989, Upslope deposition of extremely distal turbidites: An example from the Tiburon Rise, west-central Atlantic: Geology, v. 17,p. 990-994, doi:10.1130/0091-7613(1989)017<0990:UDOEDT $>2.3 . \mathrm{CO} ; 2$.

Dou, Y., Yang, S., Liu, Z., Clift, P.D., Yu, H., Berne, S., and Shi, X., 2010, Clay mineral evolution in the central Okinawa Trough since $28 \mathrm{ka}$ : Implications for sediment provenance and paleoenvironmental change: Palaeogeography, Palaeoclimatology, Palaeoecology, v. 288, p. 108-117, doi:10.1016/j .palaeo.2010.01.040.

Dou, Y., Yang, S., Liu, Z., Shi, X., Li, J., Yu, H., and Berne, S., 2012, Sr-Nd isotopic constraints on terrigenous sediment provenances and Kuroshio Current variability in the Okinawa Trough during the late Quaternary: Palaeogeography, Palaeoclimatology, Palaeoecology, v. 356-366, p. 38-47.

Expedition 319 Scientists, 2010, Expedition 319 summary, in Saffer, D., et al., eds., Proceedings of the Integrated Ocean Drilling Program, Volume 319: Washington, D.C., Integrated Ocean Drilling Program Management International, Inc., 46 p., doi:10.2204/iodp.proc.319.101.2010.

Expedition 322 Scientists, 2010a, Site C0011, in Saito, S., Underwood, M.B., Kubo, Y., and Expedition 322 Scientists, Proceedings of the Integrated Ocean Drilling Program, Volume 322: Tokyo, Integrated Ocean Drilling Program Management International, Inc., 159 p., doi:10.2204/iodp .proc.322.103.2010.

Expedition 322 Scientists, 2010b, Site C0012, in Saito, S., Underwood, M.B., Kubo, Y., and Expedition 322 Scientists, Proceedings of the Integrated Ocean Drilling Program, Volume 322: Tokyo, Integrated Ocean Drilling Program Management International, Inc., 121 p., doi:10.2204/iodp .proc.322.104.2010.

Expedition 333 Scientists, 2012a, Expedition 333 summary, in Henry, P., Kanamatsu, T., Moe, K., and the Expedition 333 Scientists, Proceedings of the Integrated Ocean Drilling Program, Volume 333: Tokyo, Integrated Ocean Drilling Program Management International, Inc., 44 p., doi:10.2204/ iodp.proc.333.101.2012.

Expedition 333 Scientists, 2012b, Site C0011, in Henry, P., Kanamatsu, T., Moe, K., and the Expedition 333 Scientists, Proceedings of the Integrated Ocean Drilling Program, Volume 333: Tokyo, Integrated Ocean Drilling Program Management International, Inc., 96 p., doi:10.2204/iodp .proc.333.104.2012.

Expedition 333 Scientists, 2012c, Site C0012, in Henry, P., Kanamatsu, T., Moe, K., and the Expedition 333 Scientists, Proceedings of the Integrated Ocean Drilling Program, Volume 333: Tokyo, Integrated Ocean Drilling Program Management International, Inc., 93 p., doi:10.2204/iodp .proc.333.105.2012.

Fagel, N., Andre, L., Chamley, H., Debrabant, P., and Jolivet, L., 1992, Clay sedimentation in the Japan Sea since the early Miocene: Influence of source-rock and hydrothermal activity: Sedimentary Geology, v. 80, p. 27-40, doi:10.1016/0037-0738(92)90029-Q.

Fagel, N., Robert, C., Preda, M., and Thorez, J., 2001, Smectite composition as a tracer of deep circulation: The case of the northern North Atlantic: Marine Geology, v. 172, p. 309-330, doi:10.1016/S0025-3227(00)00123-7.

Faure, M., and Lalevee, F., 1987, Bent structural trends of Japan: Flexural-slip folding related to the Neogene opening of the Sea of Japan: Geology, v. 15, p. 49-52, doi:10.1130/0091-7613(1987)15<49:BSTOJF>2.0.CO;2.

Fergusson, C.L., 2003, Provenance of Miocene-Pleistocene turbidite sands and sandstones, Nankai Trough, Ocean Drilling Program Leg 190, in Mikada, H., Moore, G.F., Taira, A., Becker, K., Moore, J.C., and Klaus, A., Proceedings of the Ocean Drilling Program, Scientific Results, Volume 190/196: College Station, Texas, Ocean Drilling Program, p. 1-28.

Fildani, A., and Normark, W.R., 2004, Late Quaternary evolution of channel and lobe complexes of Monterey Fan: Marine Geology, v. 206, p. 199223, doi:10.1016/j.margeo.2004.03.001.

Furuta, T., and Arai, F., 1980, Petrographic and geochemical properties of tephras in Deep Sea Drilling Project cores from the north Philippine Sea, in Klein, G.deV., Kobayashi, K., et al., Initial Reports of the Deep Sea Drilling Project, Volume 58: Washington, D.C., U.S. Government Printing Office, p. 617-625.
Gingele, F.X., Deckker, P.D., and Hillenbrand, C.-D., 2001, Clay mineral distribution in surface sediments between Indonesia and NW AustraliaSource and transport by ocean currents: Marine Geology, v. 179, p. 135146, doi:10.1016/S0025-3227(01)00194-3.

Goldfinger, C., Morey, A.E., Nelson, C.H., Gutierrez-Pastor, J., Johnson, J.E., Karabanov, E., Chaytor, J., and Eriksson, A., 2007, Rupture lengths and temporal history of significant earthquakes on the offshore and north coast segments of the Northern San Andreas Fault based on turbidite stratigraphy: Earth and Planetary Science Letters, v. 254, p. 9-27, doi:10.1016/j .epsl.2006.11.017.

Gorsline, D.S., 1984, Some thoughts on problems of fine-grained sediment production and transport, in Stow, D.A.V., and Piper, D.J.W., eds., FineGrained Sediments: Deep-Water Processes and Facies: Geological Society, London, Special Publication 15, p. 17-34.

Gardner, J.V., 2010, The West Mariana Ridge, western Pacific Ocean: Geomorphology and processes from new multibeam data: GSA Bulletin, v. 122, no. 9-10; p. 1378-1388, doi:10.1130/B30149.1.

Griggs, G.B., and Hein, J.R., 1980, Sources, dispersal, and clay-mineral composition of fine-grained sediment off central and northern California: The Journal of Geology, v. 88, p. 541-566, doi:10.1086/628543.

Gungor, A., Lee, G.H., Kim, H.-J., Han, H.-C., Kang, M.-H., Kim, J., and Sunwoo, D., 2012, Structural characteristics of the northern Okinawa Trough and adjacent areas from regional seismic reflection data: Geologic and tectonic implications: Tectonophysics, v. 522-523, p. 198-207, doi:10.1016/j.tecto.2011.11.027.

Guo, J., 2012, A Comprehensive Study of Marine Sediments of NanTroSEIZE Project, Offshore Japan: Clay Mineralogy, Consolidation, and Microfabric [Ph.D. thesis]: Columbia, Missouri, University of Missouri, 260 p.

Hall, R., 2002, Cenozoic geological and plate tectonic evolution of SE Asia and the SW Pacific: Computer-based reconstructions, model and animations: Journal of Asian Earth Sciences, v. 20, p. 353-431, doi:10.1016/S1367 $-9120(01) 00069-4$.

Hall, R., 2012, Late Jurassic-Cenozoic reconstructions of the Indonesian region and the Indian Ocean: Tectonophysics, v. 570-571, p. 1-41, doi:10 .1016/j.tecto.2012.04.021.

Hamamoto, H., Yamano, M., Goto, S., Kinoshita, M., Fujino, K., and Wang, K. 2011, Heat flow distribution and thermal structure of the Nankai subduction zone off the Kii Peninsula: Geochemistry Geophysics Geosystems, v. 12, Q0AD20, doi:10.1029/2011GC003623.

Harris, R., Yamano, M., Kinoshita, M., Spinelli, G., Hamamoto, H., and Ashi, J., 2013, A synthesis of heat flow determinations and thermal modelling along the Nankai Trough, Japan: Journal of Geophysical Research, v. 118, p. 2687-2702, doi:10.1002/jgrb.50230.

Hasebe, N., and Hoshino, H., 2003, Igneous rocks emplacement and exhumation of sedimentary basement: Fission track age determination on the Osuzuyama volcano-plutonic complex and surrounding rocks, Miyazaki prefecture, southwest Japan: Geochemical Journal, v. 37, p. 537-543, doi: $10.2343 /$ geochemj.37.537.

Hasebe, N., and Tagami, T., 2001, Exhumation of an accretionary prismResults from fission track thermochronology of the Shimanto belt, southwest Japan: Tectonophysics, v. 331, p. 247-267, doi:10.1016/S0040-1951 (00)00282-1.

Hasebe, N., and Watanabe, H., 2004, Heat flux and exhumation of the Shimanto accretionary complex: Miocene fission track ages from the Kii Peninsula, southwest Japan: The Island Arc, v. 13, p. 533-543.

Hasebe, N., Tagami, T., and Nishimura, S., 1993, The evidence of along-arc differential uplift of the Shimanto accretionary complex: Fission track thermochronology of the Kumano acidic rocks, southwest Japan: Tectonophysics, v. 224, p. 327-335, doi:10.1016/0040-1951(93)90036-J.

Hasebe, N., Tagami, T., and Nishimura, S., 1997, Mélange-forming processes in the development of an accretionary prism: Evidence from fission track thermochronology: Journal of Geophysical Research, v. 102, p. 76597672 .

Hasebe, N., Suwargadi, B.W., and Nishimura, S., 2000, Fission track ages of the Omine acidic rocks, Kii Peninsula, southwest Japan: Geochemical Journal, v. 34, p. 229-235, doi:10.2343/geochemj.34.229.

Hasegawa, A., Nakajima, J., Uchida, N., Okada, T., Zhao, D., Matsuzawa, T., and Umino, N., 2009, Plate subduction, and generation of earthquakes and magmas in Japan as inferred from seismic observations: An overview: Gondwana Research, v. 16, p. 370-400, doi:10.1016/j.gr.2009.03.007.

Hashima, A., Sato, T., Sato, H., Asao, K., Furuya, H., Yamamoto, S., Kameo, K., Miyauchi, T., Ito, T., Tsumura, N., and Kaneda, H., 2016, Simulation 
of tectonic evolution of the Kanto Basin of Japan since 1 Ma due to subduction of the Pacific and Philippine Sea plates and the collision of the Izu-Bonin arc: Tectonophysics, v. 679, p. 1-14, doi:10.1016/j .tecto.2016.04.005.

Hathon, E.G., and Underwood, M.B., 1991, Clay mineralogy and chemistry as indicators of hemipelagic sediment dispersal south of the Aleutian arc: Marine Geology, v. 97, p. 145-166, doi:10.1016/0025-3227(91)90024-X.

Hayashida, A., Kamata, H., and Danhara, T., 1996, Correlation of widespread tephra deposits based on paleomagnetic directions: Link between a volcanic field and sedimentary sequences in Japan: Quaternary International, v. 34-36, p. 89-98, doi:10.1016/1040-6182(95)00072-0.

Henry, P., and Bourlange, S., 2004, Smectite and fluid budget at Nankai ODP sites derived from cation exchange capacity: Earth and Planetary Science Letters, v. 219, p. 129-145, doi:10.1016/S0012-821X(03)00694-0.

Hibbard, J.P., and Karig, D.E., 1990, Alternative plate model for the early Miocene evolution of the southwest Japan margin: Geology, v. 18, p. 170174, doi:10.1130/0091-7613(1990)018<0170:APMFTE $>2.3 . C O ; 2$.

Higuchi, Y., Yanagimoto, Y., Hoshi, K., Unou, S., Akiba, F., Tonoike, K., and Koda, K., 2007, Cenozoic stratigraphy and sedimentation history of the northern Philippine Sea based on multichannel seismic reflection data: The Island Arc, v. 16, p. 374-393.

Hirono, T., 2003, Strain partitioning between Suruga Trough and the Zenisu thrust: Neogene to present tectonic evolution in the onland and offshore Tokai district, Japan: Tectonophysics, v. 361, p. 205-214, doi:10.1016/ S0040-1951(02)00590-5.

Honda, S., and Nakanishi, I., 2003, Seismic tomography of the uppermost mantle beneath southwestern Japan: Seismological constraints on modelling subduction and magmatism for the Philippine Sea slab: Earth, Planets, and Space, v. 55, p. 443-462, doi:10.1186/BF03351779.

Hoshi, H., and Sano, M., 2013, Paleomagnetic constraints on Miocene rotation in the central Japan Arc: The Island Arc, v. 22, p. 197-213, doi:10.1111/ iar. 12022.

Hoshi, H., Kato, D., Ando, Y., and Nakashima, K., 2015, Timing of clockwise rotation of southwest Japan: Constraints from new middle Miocene paleomagnetic results: Earth, Planets, and Space, v. 67, p. 92.

Hüpers, A., Ikari, M.J., Dugan, B., Underwood, M.B., and Kopf, A.J., 2015, Origin of a zone of anomalously high porosity in the subduction inputs to Nankai Trough: Marine Geology, v. 361, p. 147-162, doi:10.1016/j .margeo.2015.01.004.

Hyndman, R.D., Wang, K., and Yamano, M., 1995, Thermal constraints on the seismogenic portion of the southwestern Japan subduction thrust: Journal of Geophysical Research, v. 100, p. 15,373-15,392, doi:10.1029/95JB00153.

Iidaka, T., Igarashi, T., and Iwasaki, T., 2009, Configuration of the subducting Philippine Sea slab in the eastern part of southwestern Japan with seismic array and Hi-net data: Gondwana Research, v. 16, p. 504-511, doi:10.1016/j.gr.2009.05.002

Ikari, M.J., and Saffer, D.M., 2011, Comparison of frictional strength and velocity dependence between fault zones in the Nankai accretionary complex: Geochemistry, Geophysics, Geosystems, v. 12, Q0AD11, doi:10 $.1029 / 2010 \mathrm{GC} 003442$

Ikari, M.J., Saffer, D.M., and Marone, C., 2007, Effect of hydration state on the frictional properties of montmorillonite-based fault gouge: Journal of Geophysical Research, v. 112, B06423, doi:10.1029/2006JB004748.

Ikari, M.J., Hupers, A., and Kopf, A.J., 2013, Shear strength of sediments approaching subduction in the Nankai Trough, Japan, as constraints on forearc mechanics: Geochemistry Geophysics Geosystems, v. 14, p. 2716-2730, doi:10.1002/ggge.20156.

Ike, T., Moore, G.F., Kuramoto, S., Park, J.O., Kaneda, Y., and Taira, A., 2008a, Tectonics and sedimentation around Kashinosaki Knoll: A subducting basement high in the eastern Nankai Trough: The Island Arc, v. 17, p. 358-375, doi:10.1111/j.1440-1738.2008.00625.x.

Ike, T., Moore, G.F., Kuramoto, S., Park, J.O., Kaneda, Y., and Taira, A., 2008b, Variations in sediment thickness and type along the northern Philippine Sea plate at the Nankai Trough: The Island Arc, v. 17, p. 342-357, doi:10.1111/j.1440-1738.2008.00624.x.

Ishihara, T., and Koda, K., 2007, Variation of crustal thickness in the Philippine Sea deduced from three-dimensional gravity modelling: The Island Arc, v. 16, p. 322-337.

Ishii, T., Sato, H., Machida, S., Haraguchi, S., Usui, A., Ishizuka, O., Taniguchi, H., and Yagi, K., 2000, Geological and petrological studies of the Kinan and Izu-Ogasawara back arc-echelon seamount chains: Bulletin of the Geological Survey of Japan, v. 51, p. 615-630.
Ishikawa, N., 1997, Differential rotations of north Kyushu Island related to middle Miocene clockwise rotation of SW Japan: Journal of Geophysical Research, v. 102, p. 17,729-17,745, doi:10.1029/97JB01343.

Ishizuka, O., Yuasa, M., Taylor, R.N., and Sakamoto, I., 2009, Two contrasting magmatic types coexist after the cessation of back-arc spreading: Chemical Geology, v. 266, p. 283-305, doi:10.1016/j.chemgeo.2009.06.014.

Ishizuka, O., Taylor, R.N., Yuasa, M., and Ohara, Y., 2011a, Making and breaking an island arc: A new perspective from the Oligocene KyushuPalau arc, Philippine Sea: Geochemistry Geophysics Geosystems, v. 12, Q05005, doi:10.1029/2010GC003440.

Ishizuka, O., Tani, K., Reagan, M.K., Kanayama, K., Umino, S., Harigane, Y., Sakamoto, I., Miyajima, Y., Yuasa, M., and Dunkley, D.J., 2011b, The timescales of subduction initiation and subsequent evolution of an oceanic island arc: Earth and Planetary Science Letters, v. 306, p. 229-240, doi:10.1016/j.epsl.2011.04.006.

Isozaki, Y., Aoki, K., Nakama, T., and Yanai, S., 2010, New insight into a subduction-related orogen: A reappraisal of the geotectonic framework and evolution of the Japanese Islands: Gondwana Research, v. 18, p. 82-105, doi:10.1016/j.gr.2010.02.015.

Itoh, Y., and Nagasaki, Y., 1996, Crustal shortening of southwest Japan in the late Miocene: The Island Arc, v. 5, p. 337-353, doi:10.1111/j.1440-1738.1996 .tb00035.x.

Itoh, Y., Takemura, K., and Kamata, H., 1998, History of basin formation and tectonic evolution at the termination of a large transcurrent fault system: Deformation mode of central Kyushu, Japan: Tectonophysics, v. 284, p. 135-150, doi:10.1016/S0040-1951(97)00167-4.

Iwaki, H., and Hayashida, A., 2003, Paleomagnetism of Pleistocene widespread tephra deposits and its implication for tectonic rotation in central Japan: The Island Arc, v. 12, p. 46-60, doi:10.1046/j.1440-1738.2003.00378.x.

Iwano, H., Danhara, T., Hoshi, H., Kawakami, Y., Sumii, T., Shinjoe, H., and Wada, Y., 2007, Simultaneity and similarity of the Muro pyroclastic flow deposit and the Kumano acidic rocks in Kii Peninsula, southwest Japan, based on fission track ages and morphological characteristics of zircon: Journal of the Geological Society of Japan, v. 113, p. 326-339, doi:10 $.5575 /$ geosoc. 113.326

Jolivet, L., Huchon, P., and Rangin, C., 1989, Tectonic setting of western Pacific marginal basins: Tectonophysics, v. 160, p. 23-47, doi:10.1016/ 0040-1951(89)90382-X.

Kamata, H., 1989, Volcanic and structural history of the Hohi volcanic zone, central Kyushu, Japan: Bulletin of Volcanology, v. 51, p. 315-332, doi:10.1007/BF01056894.

Kamata, H., and Kodama, K., 1994, Tectonics of an arc-arc junction: An example from Kyushu Island at the junction of the southwest Japan arc and the Ryukyu arc: Tectonophysics, v. 233, p. 69-81, doi:10.1016/0040-1951 (94)90220-8.

Kamata, H., and Kodama, K., 1999, Volcanic history and tectonics of the southwest Japan arc: The Island Arc, v. 8, p. 393-403.

Kamata, H., Hayashida, A., and Danhara, T., 1997, Identification of a pair of co-ignimbrite ash and underlying distal Plinian ash in the early Pleistocene widespread tephra in Japan: Journal of Volcanology and Geothermal Research, v. 78, p. 51-64, doi:10.1016/S0377-0273(97)00011-5.

Kameda, J., Yamaguchi, A., Saito, S., Sakuma, H., Kawamura, K., and Kimura, G., 2011, A new source of water in seismogenic subduction zones: Geophysical Research Letters, v. 38, L22306, doi:10.1029/2011GL048883.

Kameda, J., Shimizu, M., Ujiie, K., Hirose, T., Ikari, M., Mori, J., Oohashi, K., and Kimura, G., 2015, Pelagic smectite as an important factor in tsunamigenic slip along the Japan Trench: Geology, v. 43, p. 155-158, doi:10.1130/G35948.1.

Kaneko, K., Kamata, H., Koyaguchi, T., Yoshikawa, M., and Furukawa, K., 2007, Repeated large-scale eruptions from a single compositionally stratified magma chamber: An example from Aso volcano, southwest Japan: Journal of Volcanology and Geothermal Research, v. 167, p. 160-180, doi:10.1016/j.jvolgeores.2007.05.002.

Karig, D.E., 1971, Origin and development of marginal basins in the western Pacific: Journal of Geophysical Research, v. 76, p. 2542-2561, doi:10 .1029/JB076i011p02542.

Karig, D.E., 1974, Evolution of arc systems in the western Pacific: Annual Review of Earth and Planetary Sciences, v. 2, p. 51-75, doi:10.1146/ annurev.ea.02.050174.000411.

Karig, D.E., Ingle, J.C., Jr., Bouma, A.H., Ellis, C.H., et al., 1975, Initial Reports of the Deep Sea Drilling Project, Volume 31: Washington, D.C., U.S. Government Printing Office, 916 p., doi:10.2973/dsdp.proc.31.1975. 
Karig, D.E., and Moore, G.F., 1975, Tectonically controlled sedimentation in marginal basins: Earth and Planetary Science Letters, v. 26, p. 233-238, doi:10.1016/0012-821X(75)90090-4.

Karlin, R., 1980, Sediment sources and clay mineral distributions off the Oregon coast: Journal of Sedimentary Petrology, v. 50, p. 543-560.

Kasuga, S., and Ohara, Y., 1997, A new model of back-arc spreading in the Parece Vela Basin, northwest Pacific margin: The Island Arc, v. 6, p. 316326, doi:10.1111/j.1440-1738.1997.tb00181.x.

Kataoka, K., Nagahashi, Y., and Yoshikawa, S., 2001, An extremely large magnitude eruption close to the Plio-Pleistocene boundary: Reconstruction of eruptive style and history of the Ebisutoge-Fukuda tephra, central Japan: Journal of Volcanology and Geothermal Research, v. 107, p. 47-69, doi:10.1016/S0377-0273(00)00300-0.

Kawakami, Y., and Hoshi, H., 2007, A ring dike and a subhorizontal sheet intrusion in a volcano-plutonic complex: Geology of the Kumano acidic rocks in the Owase-Kumano area, Kii Peninsula, Japan: Journal of the Geological Society of Japan, v. 113, p. 296-309, doi:10.5575/geosoc.113.296.

Kawamura, K., Ogawa, Y., Anma, R., Yokoyama, S., Kawakami, S., Dilek, Y., Moore, G.F., Hirano, S., Yamaguchi, A., Sasaki, T.,YK05-08 Leg 2, and YK06-02 Shipboard Scientific Parties, 2009, Structural architecture and active deformation of the Nankai accretionary prism, Japan: Submersible survey results from the Tenryu submarine canyon: Geological Society of America Bulletin, v. 121, p. 1629-1646, doi:10.1130/B26219.1.

Kawate, S., and Arima, M., 1998, Petrogenesis of the Tanzawa plutonic complex, central Japan: Exposed felsic middle crust of the Izu-Bonin-Mariana arc: The Island Arc, v. 7, p. 342-358, doi:10.1111/j.1440-1738.1998.00194.x.

Kido, Y., and Fujiwara, T., 2004, Regional variation of magnetization of oceanic crust subducting beneath the Nankai Trough: Geochemistry Geophysics Geosystems, v. 5, Q03002, doi:10.1029/2003GC000649.

Kimura, G., Hina, S., Hameda, Y., Kameda, J., Tsuji, T., Knoshita, M., and Yamaguchi, A., 2012, Runaway slip to the trench due to rupture of highly pressurized megathrust beneath the middle trench slope: The tsunamigenesis of the 2011 Tohoku earthquake off the east coast of northern Japan: Earth and Planetary Science Letters, v. 339-340, p. 32-45, doi:10.1016/j .eps1.2012.04.002.

Kimura, G., Hashimoto, Y., Kitamura, Y., Yamaguchi, A., and Koge, H., 2014, Middle Miocene swift migration of the TTT triple junction and rapid crustal growth in southwest Japan: A review: Tectonics, v. 33, p. 1219 1238, doi:10.1002/2014TC003531.

Kimura, J.-I., Stern, R.J., and Yoshida, T., 2005, Reinitiation of subduction and magmatic responses in SW Japan during Neogene time: Geological Society of America Bulletin, v. 117, p. 969-986, doi:10.1130/B25565.1.

Kimura, J.-I., Gill, J.B., Kunikiyo, T., and Osaka, I., 2014, Diverse magmatic effects of subducting a hot slab in SW Japan: Results from forward modelling: Geochemistry Geophysics Geosystems, v. 15, p. 691-739, doi:10.1002/2013GC005132.

Kimura, M., 1985, Back-arc rifting in the Okinawa Trough: Marine and Petroleum Geology, v. 2, p. 222-240, doi:10.1016/0264-8172(85)90012-1.

Kitazato, H., 1997, Paleogeographic changes in central Honshu, Japan, during the late Cenozoic in relation to the collision of the Izu-Ogasawara arc with the Honshu arc: The Island Arc, v. 6, p. 144-157, doi:10 .1111/j.1440-1738.1997.tb00166.x.

Kizaki, K., 1986, Geology and tectonics of the Ryukyu Islands: Tectonophysics, v. 125, p. 193-207, doi:10.1016/0040-1951(86)90014-4.

Klein, G.deV., 1985, The control of depositional depth, tectonic uplift, and volcanism on sedimentation processes in the back-arc basins of the western Pacific Ocean: The Journal of Geology, v. 93, p. 1-25, doi:10.1086/628916.

Klein, G.deV., and Kobayashi, K., 1981, Geological summary of the Shikoku Basin and northwestern Philippine Sea, Leg 58, DSDP/IPOD drilling results (Proceedings 26th International Geological Congress): Oceanologica Acta, p. 181-192.

Kobayashi, K., and Nakada, M., 1979, Magnetic anomalies and tectonic evolution of the Shikoku inter-arc basin, in Uyeda, S., Murphy, R., and Kobayashi, K., eds., Geodynamics of the Western Pacific: Tokyo, Japanese Scientific Society Press, p. 391-402, doi:10.1007/978-94-009-9535 $-2 \_27$.

Kobayashi, K., Kasuga, S., and Okino, K., 1995, Shikoku Basin and its margins, in Taylor, B., ed., Backarc Basins: Tectonics and Magmatism: New York, Plenum Press, p. 381-405, doi:10.1007/978-1-4615-1843-3_10.

Kodama, K., Tashiro, H., and Takeuchi, T., 1995, Quaternary counterclockwise rotation of south Kyushu, southwest Japan: Geology, v. 23, p. 823-826, doi:10.1130/0091-7613(1995)023<0823:QCROSK>2.3.CO;2.
Kopf, A., and Brown, K.M., 2003, Friction experiments on saturated sediments and their implications for the stress state of the Nankai and Barbados subduction thrusts: Marine Geology, v. 202, p. 193-210, doi:10.1016/S0025 $-3227(03) 00286-X$

Kutterolf, S., Schindlbeck, J.C., Scudder, R.P., Murray, R.W., et al., 2014, Large volume submarine ignimbrites in the Shikoku Basin: An example for explosive volcanism in the western Pacific during the late Miocene: Geochemistry Geophysics Geosystems, v. 15, p. 1837-1851, doi:10.1002/ 2014GC005263.

Lallemant, S., Chamot-Rooke, N., Le Pichon, X., and Rangin, C., 1989, Zenisu Ridge: A deep intraoceanic thrust related to subduction, off southwest Japan: Tectonophysics, v. 160, p. 151-174, doi:10.1016/0040 -1951(89)90389-2.

Lee, G.H., Kim, B., Shin, K.S., and Sunwoo, D., 2006, Geologic evolution and aspects of petroleum geology of the northern East China Sea shelf basin: American Association of Petroleum Geologists Bulletin, v. 90, p. 237 260, doi:10.1306/08010505020.

Lee, I.T., and Ogawa, Y., 1998, Bottom-current deposits in the Miocene-Pliocene Misaki Formation, Izu forearc area, Japan: The Island Arc, v. 7, p. 315-329, doi:10.1111/j.1440-1738.1998.00192.x.

Leng, W., and Gurnis, M., 2011, Dynamics of subduction initiation with different evolutionary pathways: Geochemistry Geophysics Geosystems, v. 12, Q12018, doi:10.1029/2011GC003877.

Letouzey, J., and Kimura, M., 1986, The Okinawa Trough: Genesis of a backarc basin developing along a continental margin: Tectonophysics, v. 125, p. 209-230, doi:10.1016/0040-1951(86)90015-6.

Maeno, F., and Taniguchi, H., 2007, Spatiotemporal evolution of a marine caldera-forming eruption, generating a low-aspect ratio pyroclastic flow, 7.3 ka, Kikai caldera, Japan: Implication from near-vent eruptive deposits: Journal of Volcanology and Geothermal Research, v. 167, p. 212-238, doi:10.1016/j.jvolgeores.2007.05.003.

Mahoney, J.B., 2005, Nd and $\mathrm{Sr}$ isotopic signatures of fine-grained clastic sediments: A case study of western Pacific marginal basins: Sedimentary Geology, v. 182, p. 183-199, doi:10.1016/j.sedgeo.2005.07.009.

Mahony, S.H., Wallace, L.M., Miyoshi, M., Villamor, P., Sparks, R.S.J., and Hasenaka, T., 2011, Volcano-tectonic interactions during rapid plateboundary evolution in the Kyushu region, SW Japan: Geological Society of America Bulletin, v. 123, p. 2201-2223.

Mahony, S.H., Sparks, R.S.J., Wallace, L.M., Engwell, S.L., Scourse, E.M., Barnard, N.H., Kandlbauer, J., and Brown, S.K., 2016, Increased rates of large-magnitude explosive eruptions in Japan in the late Neogene and Quaternary: Geochemistry Geophysics Geosystems, v. 17, p. 2467-2479, doi:10.1002/2016GC006362.

Marcaillou, B., Henry, P., Kinoshita, M., Kanamatsu, T., Screaton, E., Daigle, H., Harcouët-Menou, V., Lee, Y., Matsubayashi, O., Thu, M.K., Kodaira, S., Yamano, M., and the IODP Expedition 333 Scientific Party, 2012, Seismogenic zone temperatures and heat-flow anomalies in the To-nankai margin segment based on temperature data from IODP Expedition 333 and thermal model: Earth and Planetary Science Letters, v. 349-350, p. 171-185, doi:10.1016/j.eps1.2012.06.048.

Marsaglia, K.M., 1995, Interarc and backarc basins, in Busby, C.J., and Ingersoll, R.V., eds., Tectonics of Sedimentary Basins: Cambridge, Massachusetts, Blackwell, p. 299-329.

Marsaglia, K.M., Ingersoll, R.V., and Packer, B.M., 1992, Tectonic evolution of the Japanese Islands as reflected in modal compositions of Cenozoic forearc and backarc sand and sandstone: Tectonics, v. 11, p. 1028-1044.

Marsaglia, K.M., Boggs, S., Jr., Clift, R.D., Seyedolali, A., and Smith, R., 1995, Sedimentation in western Pacific backarc basins: New insights from recent ODP drilling, in Taylor, B., and Natland, J., eds., Active Margins and Marginal Basins of the Western Pacific: American Geophysical Union Geophysical Monograph 88, p. 291-314.

Martin, A.K., 2011, Double saloon door tectonics in the Japan Sea, Fossa Magna, and the Japanese island arc: Tectonophysics, v. 498, p. 45-65, doi:10.1016/j.tecto.2010.11.016.

Martinez, F., Okino, K., Ohara, Y., Reysenbach, A., and Goffredi, S.K., 2007, Back-arc basins: Oceanography (Washington, D.C.), v. 20, p. 116-127, doi:10.5670/oceanog.2007.85

Maruyama, S., Isozaki, Y., Kimura, G., and Terabayashi, M., 1997, Paleogeographic maps of the Japanese Islands: Plate tectonic synthesis from $750 \mathrm{Ma}$ to the present: The Island Arc, v. 6, p. 121-142.

Masuda, H., O'Neil, J.R., Jiang, W.-T., and Peacor, D.R., 1996, Relation between interlayer composition of authigenic smectite, mineral 
assemblages, I/S reaction rate and fluid composition in silicic ash of the Nankai Trough: Clays and Clay Minerals, v. 44, p. 443-459, doi:10.1346/ CCMN.1996.0440402.

Masuda, H., Peacor, D.R., and Dong, H., 2001, Transmission electron microscopy study of conversion of smectite to illite in mudstones of the Nankai Trough: Contrasts with coeval bentonites: Clays and Clay Minerals, v. 49, p. 109-118, doi:10.1346/CCMN.2001.0490201.

Mazzotti, S., Lallemant, S.J., Henry, P., Le Pichon, X., Tokuyama, H., and Takahashi, N., 2002, Intraplate shortening and underthrusting of a large basement ridge in the eastern Nankai subduction zone: Marine Geology, v. 187 , p. 63-88, doi:10.1016/S0025-3227(02)00245-1.

McHugh, C.M.G., Ryan, W.B.F., Eittreim, S., and Reed, D., 1998, The influence of the San Gregorio fault on the morphology of Monterey Canyon: Marine Geology, v. 146, p. 63-91, doi:10.1016/S0025-3227(97)00118-7.

Miki, M., 1995, Two-phase opening model for the Okinawa Trough inferred from paleomagnetic study of the Ryukyu arc: Journal of Geophysical Research, v. 100, p. 8169-8184.

Miura, D., and Wada, Y., 2007, Middle Miocene ash-flow calderas at the compressive margin of southwest Japan arc: Review and synthesis: Journal of the Geological Society of Japan, v. 113, p. 283-295, doi:10.5575/ geosoc.113.283.

Molina-Cruz, A., 1997, Closing of the Central American Gateway and its effects on the distribution of late Pliocene radiolarians in the eastern tropical Pacific: Tectonophysics, v. 281, p. 105-111, doi:10.1016/S0040 -1951(97)00162-5.

Moore, G.F., Taira, A., Klaus, A., Becker, L., et al., 2001a, New insights into deformation and fluid flow processes in the Nankai Trough accretionary prism: Results of Ocean Drilling Program Leg 190: Geochemistry Geophysics Geosystems, v. 2, GC000166, doi:10.1029/2001GC000166.

Moore, G.F., Taira, A. Bangs, N.L., Kuramoto, S., Shipley, T.H., Alex, C.M., Gulick, S.S., Hills, D.J., Ike, T., Ito, S., Leslie, S.C., McCutcheon, A.J., Mochizuki, K., Morita, S., Nakamura, Y., Park, J.-O., Taylor, B.L., Toyama, G., Yagi, H., and Zhao, Z., 2001b, Data report: Structural setting of the Leg 190 Muroto transect, in Moore, G.F., Taira, A., Klaus, A., et al., Proceedings of the Ocean Drilling Program, Initial Reports, Volume 190: College Station, Texas, Ocean Drilling Program, p. 1-14.

Mountjoy, J.J., Barnes, P.M., and Pettinga, J.R., 2009, Morphostructure and evolution of submarine canyons across an active margin: Cook Strait sector of the Hikurangi margin, New Zealand: Marine Geology, v. 260, p. 45-68, doi:10.1016/j.margeo.2009.01.006.

Mountney, N.P., and Westbrook, G.K., 1996, Modelling sedimentation in ocean trenches: The Nankai Trough from 1 Ma to the present: Basin Research, v. 8, p. 85-101, doi:10.1111/j.1365-2117.1996.tb00116.x.

Muck, M., and Underwood, M., 1990, Upslope flow of turbidity currents: A comparison among field observations, theory, and laboratory models: Geology, v. 18, p. 54-57, doi:10.1130/0091-7613(1990)018<0054: UFOTCA $>2.3 . \mathrm{CO} ; 2$

Nagahashi, Y., and Satoguchi, Y., 2007, Stratigraphy of the Pliocene to lower Pleistocene marine formations in Japan on the basis of tephra beds correlation: Quaternary Research, v. 46, p. 205-213, doi:10.4116/jaqua.46.205.

Nagahashi, Y., Satoguchi, Y., and Yoshikawa, S., 2000, Correlation and stratigraphic eruption age of the pyroclastic flow deposits and wide spread volcanic ashes intercalated in the Pliocene1Pleistocene strata, central Japan: Journal of the Geological Society of Japan, v. 106, p. 51-69, doi:10.5575/ geosoc.106.51.

Naidu, A.S., and Mowatt, T.C., 1983, Sources and dispersal paths of clay minerals in surface sediments from the continental shelf areas off Alaska: Geological Society of America Bulletin, v. 94, p. 841-854, doi:10.1130/0016 $-7606(1983) 94<841$ :SADPOC $>2.0$. CO;2.

Nakajima, J., and Hasegawa, A., 2007, Subduction of the Philippine Sea plate beneath southwestern Japan: Slab geometry and its relationship to arc magmatism: Journal of Geophysical Research, v. 112, B08306, doi:10.1029/2006JB004770.

Nakajima, J., Tsuji, Y., Hasegawa, A., Kita, S., Okada, T., and Matsuzawa, T., 2009, Tomographic imaging of hydrated crust and mantle in the subducting Pacific slab beneath Hokkaido, Japan: Evidence for dehydration embrittlement as a cause of intraslab earthquakes: Gondwana Research, v. 16, p. 470-481, doi:10.1016/j.gr.2008.12.010.

Nakajima, T., 1997, Regional metamorphic belts of the Japanese Islands: The Island Arc, v. 6, p. 69-90.

Nakamura, H., Oikawa, T., Geshi, N., and Matsumoto, A., 2014, Migration of a volcanic front inferred from K-Ar ages of late Miocene to Pliocene volca- nic rocks in central Japan: The Island Arc, v. 23, p. 236-250, doi:10.1111/ iar.12073.

Niitsuma, N., 1989, Collision tectonics in the southern Fossa Magna, central Japan: Modern Geology, v. 14, p. 3-18.

Normark, W.R., Piper, D.J.W., Romans, B.W., Covault, J.A., Dartnell, P., and Sliter, R.W., 2009, Submarine canyon and fan systems of the California Continental Borderland, in Lee, H.J., and Normark, W.R., eds., Earth Science in the Urban Ocean: The Southern California Continental Borderland: Geological Society of America Special Paper 454, p. 141-168, doi:10.1130/2009.2454(2.7).

Obara, K., 2009, Inhomogeneous distribution of deep slow earthquake activity along the strike of the subducting Philippine Sea plate: Gondwana Research, v. 16, p. 512-526, doi:10.1016/j.gr.2009.04.011.

Ogawa, Y., Horiuchi, K., Taniguchi, H., and Naka, J., 1985, Collision of the Izu arc with Honshu and the effects of oblique subduction in the MiuraBoso Peninsulas: Tectonophysics, v. 119, p. 349-379, doi:10.1016/0040 -1951(85)90046-0.

Oiwane, H., Tonai, S., Kiyokawa, S., Nakamura, Y., Suganuma, Y., and Tokuyama, H., 2011, Geomorphological development of the Goto Submarine Canyon, northeastern East China Sea: Marine Geology, v. 288 , p. 49-60, doi:10.1016/j.margeo.2011.06.013.

Okamura, Y., 2003, Fault-related folds and an imbricate thrust system on the northwestern margin of the northern Fossa Magna region, central Japan: The Island Arc, v. 12, p. 61-73, doi:10.1046/j.1440-1738.2003.00379.x.

Okamura, Y., 2016, Active tectonics around the junction of southwest Japan and Ryukyu arcs: Control by subducting plate geometry and pre-Quaternary geologic structure: The Island Arc, v. 25, p. 287-297.

Okino, K., Shimakawa, Y., and Nagaoka, S., 1994, Evolution of the Shikoku Basin: Journal of Geomagnetism and Geoelectricity, v. 46, p. 463-479, doi:10.5636/jgg.46.463.

Okino, K., Ohara, Y., Kasuga, S., and Kato, Y., 1999, The Philippine Sea: New survey results reveal the structure and the history of the marginal basins: Geophysical Research Letters, v. 26, p. 2287-2290, doi:10.1029/ 1999GL900537.

Oleskevich, D.A., Hyndman, R.D., and Wang, K., 1999, The updip and downdip limits to great subduction earthquakes: Thermal and structural models of Cascadia, south Alaska, SW Japan, and Chile: Journal of Geophysical Research, v. 104, p. 14,965-14,991, doi:10.1029/1999JB900060.

Orihashi, Y., Iwano, H., Hirata, T., Danhara, T., and Shinjoe, H., 2007, U-Pb ages and trace element compositions of reddish, colorless, and detrital zircons in the Kumano acidic rocks in the Outer Zone of southwest Japan and origin of the host magmas: Journal of the Geological Society of Japan, v. 113, p. 366-383, doi:10.5575/geosoc.113.366.

Osborn, M.J., and Swarbrick, R.E., 1997, Mechanisms for generating overpressure in sedimentary basins-A reevaluation: American Association of Petroleum Geologists Bulletin, v. 81, p. 1023-1041.

Otofuji, Y., 1996, Large tectonic movement of the Japan Arc in late Cenozoic times inferred from paleomagnetism: Review and synthesis: Island Arc, v. 5, p. 229-249.

Otofuji, Y., Matsuda, T., and Nohda, S., 1985, Opening mode of the Japan Sea inferred from the palaeomagnetism of the Japan arc: Nature, v. 317 , p. 603-604, doi: $10.1038 / 317603 \mathrm{a} 0$.

Otofuji, Y., Matsuda, T., and Nohda, S., 1986, Brief review of Miocene opening of the Japan Sea: Paleomagnetic evidence from the Japan arc: Journal of Geomagnetism and Geoelectricity, v. 38, p. 287-294, doi:10.5636/ jgg.38.287.

Otofuji, Y., Enami, R., Yokoyama, M., Kamiya, K., Kuma, S., Saito, H., and Matsuda, T., 1999, Miocene clockwise rotation of southwest Japan and formation of curvature of the Median Tectonic Line: Paleomagnetic implications: Journal of Geophysical Research, v. 104, p. 12,895-12,907.

Park, J.-O., Tokuyama, H., Shinohara, M., Suyehiro, K., and Taira, A., 1998, Seismic record of tectonic evolution and backarc rifting in the southern Ryukyu island arc system: Tectonophysics, v. 294, p. 21-42, doi:10.1016/ S0040-1951(98)00150-4.

Parra, M., Delmont, P., Ferragne, A., Latouche, C., Pons, J.C., and Puechmaille, C., 1985, Origin and evolution of smectite in recent marine sediments of the NE Atlantic: Clay Minerals, v. 20, p. 335-346, doi:10.1180/ claymin.1985.020.3.06.

Parra, M., Pons, J.C., and Ferragne, A., 1986, Two potential sources for Holocene clay sedimentation in the Caribbean Basin: The Lesser Antilles arc and the South American continent: Marine Geology, v. 72, p. 287-304, doi:10.1016/0025-3227(86)90124-6. 
Paull, C.K., Caress, D.W., Ussler, W., III, Lundsten, E., and Meiner-Johnson, M., 2011, High-resolution bathymetry of the axial channels within Monterey and Soquel submarine canyons, offshore central California: Geosphere, v. 7, p. 1077-1101.

Petschick, R., Kuhn, G., and Gingele, F., 1996, Clay mineral distribution in surface sediments of the South Atlantic: Sources, transport, and relation to oceanography: Marine Geology, v. 130, p. 203-229, doi:10.1016/0025 -3227(95)00148-4.

Phillips, S.C., Johnson, J.E., Underwood, M.B., Guo, J., Giosan, L., and Rose, K., 2014, Long-timescale variation in bulk and clay mineral composition of Indian continental margin sediments in the Bay of Bengal, Arabian Sea, and Andaman Sea: Marine and Petroleum Geology, v. 58, p. 117-138, doi:10.1016/j.marpetgeo.2014.06.018.

Pickering, K.T., Underwood, M.B., and Taira, A., 1992, Open ocean to trench turbidity-current flow in the Nankai Trough: Flow collapse and reflection: Geology, v. 20, p. 1099-1102, doi:10.1130/0091-7613 (1992)020<1099:OOTTTC >2.3.CO;2.

Pickering, K.T., Underwood, M.B., Saito, S., Naruse, H., Kutterolf, S., Scudder, R., Park, J.-O., Moore, G.F., and Slagle, A., 2013, Depositional architecture, provenance, and tectonic/eustatic modulation of Miocene submarine fans in the Shikoku Basin: Results from the Nankai Trough Seismogenic Zone Experiment: Geochemistry Geophysics Geosystems, v. 14, p. 1722 1739, doi:10.1002/ggge.20107.

Piper, D.J.W., von Huene, R., and Duncan, J.R., 1973, Late Quaternary sedimentation in the active eastern Aleutian Trench: Geology, v. 1, p. 19-26, doi:10.1130/0091-7613(1973)1<19:LQSITA>2.0.CO;2.

Pollard, R., and Read, J., 2015, Circulation, stratification and seamounts in the southwest Indian Ocean: Deep-Sea Research II, v. 136, p. 36-43.

Ranken, B., Cardwell, R.K., and Karig, D.E., 1984, Kinematics of the Philippine Sea plate: Tectonics, v. 3, p. 555-575, doi:10.1029/TC003i005p00555.

Read, J., and Pollard, R., 2015, An introduction to the physical oceanography of six seamounts in the southwest Indian Ocean: Deep-Sea Research II, v. 136, p. $44-58$.

Saffer, D.M., and Bekins, B.A., 2006, An evaluation of factors influencing pore pressure in accretionary complexes: Implications for taper angle and wedge mechanics: Journal of Geophysical Research, v. 111, B04101, doi:10.1029/2005JB003990.

Saffer, D.M., and Marone, C., 2003, Comparison of smectite- and illite-rich gouge frictional properties: Application to the updip limit of the seismogenic zone along subduction megathrusts: Earth and Planetary Science Letters, v. 215, p. 219-235, doi:10.1016/S0012-821X(03)00424-2.

Saffer, D.M., and McKiernan, A.W., 2009, Evaluation of in situ smectite dehydration as a pore water freshening mechanism in the Nankai Trough, offshore southwest Japan: Geochemistry Geophysics Geosystems, v. 10, Q02010, doi:10.1029/2008GC002226.

Saffer, D.M., and Tobin, H.J., 2011, Hydrogeology and mechanics of subduction zone forearcs: Fluid flow and pore pressure: Annual Review of Earth and Planetary Sciences, v. 39, p. 157-186, doi:10.1146/annurev-earth $-040610-133408$.

Saffer, D.M., and Wallace, L.M., 2015, The frictional, hydrologic, metamorphic and thermal habitat of shallow slow earthquakes: Nature Geoscience, v. 8, p. 594-600, doi:10.1038/ngeo2490.

Saffer, D.M., Underwood, M.B., and McKiernan, A.W., 2008, Evaluation of factors controlling smectite transformation and fluid production in subduction zones: Application to the Nankai Trough: Island Arc, v. 17, p. 208-230.

Saito, K., Kato, K., and Sugi, S., 1997, K-Ar dating studies of Ashigawa and Tokuwa granodiorite bodies and plutonic geochronology in the South Fossa Magna, central Japan: The Island Arc, v. 6, p. 158-167, doi:10.1111/j.1440-1738.1997.tb00167.x.

Saitoh, Y., Ishikawa, T., Tanimizu, M., Murayama, M., Ujiie, Y., Yamamoto, Y., Ujiie, K., and Kanamatsu, T., 2015, Sr, Nd, and Pb isotope compositions of hemipelagic sediment in the Shikoku Basin: Implications for sediment transport by the Kuroshio and Philippine Sea plate motion in the late Cenozoic: Earth and Planetary Science Letters, v. 421, p. 47-57, doi:10.1016/j.eps1.2015.04.001.

Sato, H., Machida, S., Kanayama, S., Taniguchi, H., and Ishii, T., 2002, Geochemical and isotopic characteristics of the Kinan seamount chain in the Shikoku Basin: Geochemical Journal, v. 36, p. 519-526.

Satoguchi, Y., 1995, Tephrastratigraphy in the lower to middle Kazusa Group in the Boso Peninsula, Japan: Journal of the Geological Society of Japan, v. 101, p. 767-782, doi:10.5575/geosoc.101.767.
Satoguchi, Y., Higuchi, Y., and Kurokawa, K., 2005, Correlation of the Ohta tephra bed in the Tokai Group with a tephra bed in the Miura Group, central Japan: Journal of the Geological Society of Japan, v. 111, p. 74-86, doi:10.5575/geosoc.111.74.

Schindlbeck, J.C., Kutterolf, S., Freundt, A., Scudder, R.P., Pickering, K.T., and Murray, R.W., 2013, Emplacement processes of submarine volcaniclastic deposits (IODP Site C0011, Nankai Trough): Marine Geology, v. 343, p. 115-124, doi:10.1016/j.margeo.2013.06.017.

Schoonover, M., and Osozawa, S., 2004, Exhumation process of the Nago subduction-related metamorphic rocks, Okinawa, Ryukyu island arc: Tectonophysics, v. 393, p. 221-240, doi:10.1016/j.tecto.2004.07.036.

Screaton, E., Kimura, G., Curewitz, D., and the Expedition 316 Scientists, 2009a, Expedition 316 summary, in Kinoshita, M., et al., eds., Proceedings of the Integrated Ocean Drilling Program, Volumes 314/315/316: Washington, D.C., Integrated Ocean Drilling Program Management International, Inc., 29 p., doi:10.2204/iodp.proc.314315316.131.2009.

Screaton, E., Kimura, G., Curewitz, D., Moore G., et al., 2009b, Interactions between deformation and fluids in the frontal thrust region of the NanTroSEIZE transect offshore the Kii Peninsula, Japan: Results from IODP Expedition 316 Sites C0006 and C0007: Geochemistry Geophysics Geosystems, v. 10, Q0AD01, doi:10.1029/2009GC002713.

Sdrolias, M., Roest, W.R., and Müller, R.D., 2004, An expression of Philippine Sea plate rotation: The Parece Vela and Shikoku Basins: Tectonophysics, v. 394, p. 69-86, doi:10.1016/j.tecto.2004.07.061.

Seno, T., 1977, The instantaneous rotation vector of the Philippine Sea plate relative to the Eurasian plate: Tectonophysics, v. 42, p. 209-226, doi:10.1016/0040-1951(77)90168-8.

Seno, T., 1985, Age of subducting lithosphere and back-arc basin formation in the western Pacific since the middle Tertiary, in Nasu, N., et al., eds., Formation of Active Ocean Margins: Tokyo, Terra Scientific Publishing Company, p. 469-481.

Seno, T., 2009, Determination of the pore pressure ratio at seismogenic megathrusts in subduction zones: Implications for strength of asperities and Andean-type mountain building: Journal of Geophysical Research, v. 114, B05405, doi:10.1029/2008JB005889.

Seno, T., and Maruyama, S., 1984, Paleogeographic reconstruction and origin of the Philippine Sea: Tectonophysics, v. 102, p. 53-84, doi:10.1016/0040 -1951(84)90008-8.

Seton, M., Muller, R.D., Zahirovic, S., Gaina, C., Torsvik, T., Shephard, G., Talsma, A., Gurnis, M., Turner, M., Maus, S., and Chandler, M., 2012, Global continental and ocean basin reconstructions since $200 \mathrm{Ma}$ : Earth-Science Reviews, v. 113, p. 212-270, doi:10.1016/j.earscirev.2012.03.002.

Shimamura, K., 1989, Topography and sedimentary facies of the Nankai deep sea channel, in Taira, A., and Masuda, F., eds., Sedimentary Facies in the Active Plate Margin: Tokyo, Terra Scientific Publishing Company, p. 529-556.

Shimoda, G., Tatsumi, Y., Nohda, S., Ishizaka, K., and John, B.M., 1998, Setouchi high- $\mathrm{Mg}$ andesites revisited: Geochemical evidence for melting of subducting sediments: Earth and Planetary Science Letters, v. 160, p. 479-492, doi:10.1016/S0012-821X(98)00105-8.

Shimoda, G., Tatsumi, Y., and Morishita, Y., 2003, Behavior of subducting sediments beneath an arc under a high geothermal gradient: Constraints from the Miocene SW Japan arc: Geochemical Journal, v. 37, p. 503-518, doi:10.2343/geochemj.37.503.

Shinjoe, H., Orihashi, Y., Wada, Y., Sumii, T., and Nakai, S., 2007, Regional variation of whole rock chemistry of the Miocene felsic igneous rocks in the Kii Peninsula, southwest Japan: Journal of the Geological Society of Japan, v. 113, p. 310-325, doi:10.5575/geosoc.113.310.

Shipboard Scientific Party, 1991, Site 808, in Taira, A., Hill, I., Firth, J., et al., Proceedings of the Ocean Drilling Program, Initial Reports, Volume 131: College Station, Texas, Ocean Drilling Program, p. 71-269.

Shipboard Scientific Party, 2001a, Site 1173, in Moore, G.F., Taira, A., Klaus, A., et al., Proceedings of the Ocean Drilling Program, Initial Reports, Volume 190: College Station, Texas, Ocean Drilling Program, 147 p.

Shipboard Scientific Party, 2001b, Site 1177, in Moore, G.F., Taira, A., Klaus, A., et al., Proceedings of the Ocean Drilling Program, Initial Reports, Volume 190: College Station, Texas, Ocean Drilling Program, 91 p.

Sibuet, J.-C., Letouzey, J., Barbier, F., Charvet, J., Foucher, J.-P., Hilde, T.W.C., Kimura, M., Chiao, L.-Y., Marsset, B., Muller, C., and Stéphan, J.-F., 1987, Back arc extension in the Okinawa Trough: Journal of Geophysical Research, v. 92, p. 14,041-14,063, doi:10.1029/JB092iB13p14041.

Sibuet, J.-C., Hsu, S.K., Shyu, C.T., and Liu, C.S., 1995, Structural and kinematic evolutions of the Okinawa Trough backarc basin, in Taylor, B., ed., 
Backarc Basins: Tectonics and Magmatism: New York, Plenum Press, p. 343-379, doi:10.1007/978-1-4615-1843-3_9.

Sibuet, J.-C., Deffontaines, B., Hsu, S.-K., Thareau, N., Le Formal, J.-P., and Liu, C.-S., 1998, Okinawa Trough backarc basin: Early tectonic and magmatic evolution: Journal of Geophysical Research, v. 103, p. 30,24530,267, doi:10.1029/98JB01823.

Soh, W., and Tokuyama, H., 2002, Rejuvenation of submarine canyon associated with ridge subduction, Tenryu Canyon, off Tokai, central Japan: Marine Geology, v. 187, p. 203-220, doi:10.1016/S0025-3227(02)00267-0.

Soh, W., Pickering, K.T., Taira, A., and Tokuyama, H., 1991, Basin evolution in the arc-arc Izu collision zone, Mio-Pliocene Miura Group, central Japan: Journal of the Geological Society, London, v. 148, p. 317-330, doi:10.1144/gsjgs.148.2.0317.

Soh, W., Tanaka, T., and Taira, A., 1995, Geomorphology and sedimentary processes of a modern slope-type fan delta (Fujikawa fan delta), Suruga Trough, Japan: Sedimentary Geology, v. 98, p. 79-95, doi:10.1016/0037 -0738 (95)00028-7.

Soh, W., Nakayama, K., and Kimura, T., 1998, Arc-arc collision in the Izu collision zone, central Japan, deduced from the Ashigara Basin and adjacent Tanzawa Mountains: The Island Arc, v. 7, p. 330-341, doi:10.1111/ j.1440-1738.1998.00193.x.

Spinelli, G.A., and Underwood, M.B., 2004, Character of sediments entering the Costa Rica subduction zone: Implications for partitioning of water along the plate interface: The Island Arc, v. 13, p. 432-451, doi:10.1111/ j.1440-1738.2004.00436.x.

Spinelli, G.A., and Underwood, M.B., 2005, Modeling thermal history of subducting crust in Nankai Trough: Constraints from in situ sediment temperature and diagenetic reaction progress: Geophysical Research Letters, v. 32, L09301, doi:10.1029/2005GL022793.

Spinelli, G.A., Mozley, P.S., Tobin, H.J., Underwood, M.B., Hoffman, N.W., and Bellew, G.M., 2007, Diagenesis, sediment strength, and pore collapse in sediment approaching the Nankai Trough subduction zone: Geological Society of America Bulletin, v. 119, p. 377-390.

Steinke, S., Hanebuth, T.J.J., Vogt, C., and Stattegger, K., 2008, Sea level induced variations in clay mineral composition in the southwestern South China Sea over the past 17,000 yr: Marine Geology, v. 250, p. 199-210, doi:10.1016/j.margeo.2008.01.005.

Stern, R.J., 2004, Subduction initiation: Spontaneous and induced: Earth and Planetary Science Letters, v. 226, p. 275-292, doi:10.1016/S0012 -821X(04)00498-4.

Stern, R.J., 2010, The anatomy and ontogeny of modern intra-oceanic arc systems, in Kusky, T.M., Zhai, M.G., and Xiao, W., eds., The Evolving Continents: Understanding Processes of Continental Growth: Geological Society, London, Special Publication 338, p. 7-34, doi:10.1144/SP338.2.

Steurer, J.F., and Underwood, M.B., 2003, Clay mineralogy of mudstones from the Nankai Trough reference sites and frontal accretionary prism, in Mikada, H., Moore, G.F., Taira, A., Becker, K., Moore, J.C., and Klaus, A., et al., Proceedings of the Ocean Drilling Program, Scientific Results, Volume 190/196: College Station, Texas, Ocean Drilling Program, 37 p., doi:10.2973/odp.proc.sr.190196.211.2003.

Strasser, M., Dugan, B., Kanagawa, K., Moore, G.F., Toczko, S., Maeda, L., Kido, Y., Moe, K.T., Sanada, Y., Esteban, L., Fabbri, O., Geersen, J., Hammerschmidt, S., Hayashi, H., Heirman, K., Hüpers, A., Jurado Rodriguez, M.J., Kameo, K., Kanamatsu, T., Kitajima, H., Masuda, H., Milliken, K., Mishra, R., Motoyama, I., Olcott, K., Oohashi, K., Pickering, K.T., Ramirez, S.G., Rashid, H., Sawyer, D., Schleicher, A., Shan, Y., Skarbek, R., Song, I., Takeshita, T., Toki, T., Tudge, J., Webb, S., Wilson, D.J., Wu, H.-Y., and Yamaguchi, A., 2014, Expedition 338 summary, in Strasser, M., et al., Proceedings of the Integrated Ocean Drilling Program, Volume 338: Yokohama, Japan, Integrated Ocean Drilling Program47 p., doi:10.2204/iodp.proc.338.101.2014.

Sueoka, S., Kohn, B.P., Tagami, T., Tsutsumi, H., Hasebe, N., Tamura, A., and Arai, S., 2012, Denudation history of the Kiso Range, central Japan, and its tectonic implications: Constraints from low-temperature thermochronology: The Island Arc, v. 21, p. 32-52, doi:10.1111/j.1440-1738 .2011.00789.x

Taira, A., 2001, Tectonic evolution of the Japanese island arc system: Annual Review of Earth and Planetary Sciences, v. 29, p. 109-134, doi:10.1146/ annurev.earth.29.1.109.

Taira, A., and Niitsuma, N., 1986, Turbidite sedimentation in the Nankai Trough as interpreted from magnetic fabric, grain size, and detrital mode analyses, in Kagami, H., Karig, D.E., Coulbourn, W.T., et al., Initial Reports of the Deep Sea Drilling Project, Volume 87: Washington, D.C., U.S. Government Printing Office, p. 611-632.

Taira, A., Katto, J., Tashiro, M., Okamura, M., and Kodama, K., 1988, The Shimanto belt in Shikoku Japan-Evolution of Cretaceous to Miocene accretionary prism: Modern Geology, v. 12, p. 5-46.

Taira, A., Hill, I., Firth, J., Berner, U., Bruckmann, W., Byrne, T., Chabernaud, T., Fisher, A., Foucher, J.-P., Gamo, T., Gieskes, J., Hyndman, R., Karig, D., Kastner, M., Kato, Y., Lallemant, S., Lu, R., Maltman, A., Moore, G., Moran, K., Olaffson, G., Owens, W., Pickering, K.T., Siena, F., Taylor, E., Underwood, M., Wilkinson, C., Yamano, M., and Zhang, J., 1992, Sediment deformation and hydrogeology of the Nankai Trough accretionary prism: Synthesis of shipboard results of ODP Leg 131: Earth and Planetary Science Letters, v. 109, p. 431-450, doi:10.1016/0012-821X (92)90104-4.

Takahashi, M., and Saito, K., 1997, Miocene intra-arc bending at an arcarc collision zone, central Japan: The Island Arc, v. 6, p. 168-182, doi:10.1111/j.1440-1738.1997.tb00168.x.

Tamaki, K., 1995, Opening tectonics of the Japan Sea, in Taylor, B., ed., Backarc Basins: Tectonics and Magmatism: New York, Plenum Press, p. 407420, doi:10.1007/978-1-4615-1843-3_11.

Tamura, I., Yamazaki, H., and Mizuno, K., 2008, Characteristics for recognition of Pliocene and early Pleistocene marker tephras in central Japan: Quaternary International, v. 178, p. 85-99, doi:10.1016/j.quaint.2007.04.002.

Tani, K., Dunkley, D.J., Kimura, J.-L., Wysoczanski, R.J., Yamada, K., and Tatsumi, Y., 2010, Syncollisional rapid granitic magma formation in an arcarc collision zone: Evidence from the Tanzawa plutonic complex, Japan: Geology, v. 38, p. 215-218.

Tatsumi, Y., 2006, High-Mg andesites in the Setouchi volcanic belt, southwestern Japan: Analogy to Archean magmatism and continental crust formation?: Annual Review of Earth and Planetary Sciences, v. 34, p. 467-499, doi:10.1146/annurev.earth.34.031405.125014.

Tatsumi, Y., Ishikawa, N., Anno, K., Ishizaka, K., and Itaya, T., 2001, Tectonic setting of high-Mg andesite magmatism in the SW Japan arc: K-Ar chronology of the Setouchi volcanic belt: Geophysical Journal International, v. 144, p. 625-631, doi:10.1046/j.1365-246x.2001.01358.x.

Taylor, B., 1992, Rifting and the volcanic-tectonic evolution of the IzuBonin-Mariana arc, in Taylor, B., Fujioka, K., et al., Proceedings of the Ocean Drilling Program, Scientific Results, Volume 126: College Station, Texas, Ocean Drilling Program, p. 627-651, doi:10.2973/odp.proc sr.126.163.1992.

Taylor, B., and Karner, G.D., 1983, On the evolution of marginal basins: Reviews of Geophysics and Space Physics, v. 21, p. 1727-1741.

Teng, L.S., and Gorsline, D.S., 1989, Late Cenozoic sedimentation in California Continental Borderland basins as revealed by seismic facies analysis: Geological Society of America Bulletin, v. 101, p. 27-41, doi:10.1130/0016-7606(1989)101<0027:LCSICC>2.3.CO;2.

Thiry, M., 2000, Palaeoclimatic interpretation of clay minerals in marine deposits: An outlook from the continental origin: Earth-Science Reviews, v. 49, p. 201-221, doi:10.1016/S0012-8252(99)00054-9.

Tobin, H., and Kinoshita, M., 2006, NanTroSEIZE: The IODP Nankai Trough Seismogenic Zone Experiment: Scientific Drilling, v. 2, p. 23-27, doi:10.5194/sd-2-23-2006.

Tobin, H., and Saffer, D.M., 2009, Elevated fluid pressure and extreme mechanical weakness of a plate boundary thrust, Nankai Trough subduction zone: Geology, v. 37, p. 679-682, doi:10.1130/G25752A.1.

Tobin, H., Kinoshita, M., Moe, K.T., and the Expedition 314 Scientists, 2009, Expedition 314 summary, in Kinoshita, M., et al., Proceedings of the Integrated Ocean Drilling Program, Volume 314/315/316: Washington, D.C., Integrated Ocean Drilling Program Management International, Inc. 42 p., doi:10.2204/iodp.proc.314315316.111.2009.

Tobin, H., Hirose, T., Saffer, D., Toczko, S., Maeda, L., Kubo, Y., Boston, B. Broderick, A., Brown, K., Crespo-Blanc, A., Even, E., Fuchida, S., Fukuchi, R., Hammerschmidt, S., Henry, P., Josh, M., Jurado, M.J., Kitajima, H., Kitamura, M., Maia, A., Otsubo, M., Sample, J., Schleicher, A., Sone, H., Song, C., Valdez, R., Yamamoto, Y., Yang, K., Sanada, Y., Kido, Y., and Hamada, Y., 2015, Expedition 348 summary, in Tobin, H., et al., Proceedings of the Integrated Ocean Drilling Program, Volume 348: College Station, Texas, Integrated Ocean Drilling Program, 46 p., doi:10.2204/ iodp.proc.348.101.2015

Toriumi, M., and Arai, T., 1989, Metamorphism of the Izu-Tanzawa collision zone: Tectonophysics, v. 160, p. 293-303. 
Tsuchi, R., 1997, Marine climate responses to Neogene tectonics of the Pacific Ocean seaways: Tectonophysics, v. 281, p. 113-124, doi:10.1016/S0040 -1951(97)00163-7.

Tsuji, T., Matsuoka, T., Yamada, Y., Nakamura, Y., Ashi, J., Tokuyama, H., Kuramoto, S., and Bangs, N., 2005, Initiation of the plate boundary slip in the Nankai Trough off the Muroto Peninsula, southwest Japan: Geophysical Research Letters, v. 32, L12306, doi:10.1029/2004GL021861.

Turnewitsch, R., Falahat, S., Nycander, J., Dale, A., Scott, R.B., and Furnival, D., 2013, Deep-sea fluid and sediment dynamics-Influence of hill- to seamount-scale seafloor topography: Earth-Science Reviews, v. 127, p. 203-241, doi:10.1016/j.earscirev.2013.10.005.

Ujiié, H., and Ujiié, Y., 1999, Late Quaternary course changes of the Kuroshio Current in the Ryukyu arc region, northwestern Pacific Ocean: Marine Micropaleontology, v. 37, p. 23-40, doi:10.1016/S0377-8398(99)00010-9.

Ujiie, K., 1997, Off-scrapping accretionary process under the subduction of young oceanic crust: The Shimanto belt of Okinawa Island, Ryukyu arc: Tectonics, v. 16, p. 305-322, doi:10.1029/96TC03367.

Ujiie, K., Hisamitsu, T., and Taira, A., 2003, Deformation and fluid pressure variation during initiation and evolution of the plate boundary décollement zone in the Nankai accretionary prism: Journal of Geophysical Research, v. 108, no. B8, 2398, doi:10.1029/2002JB002314.

Underwood, M.B., 2007, Sediment inputs to subduction zones: Why lithostratigraphy and clay mineralogy matter, in Dixon, T., and Moore, J.C., eds., The Seismogenic Zone of Subduction Thrust Faults: New York, Columbia University Press, p. 42-85, doi:10.7312/dixo13866-003.

Underwood, M.B., and Fergusson, C.L., 2005, Late Cenozoic evolution of the Nankai trench-slope system: Evidence from sand petrography and clay mineralogy, in Hodgson, D., and Flint, S., eds., Submarine Slope Systems: Processes, Products and Prediction: Geological Society, London, Special Publication 244, p. 113-129, doi:10.1144/GSL.SP.2005.244.01.07.

Underwood, M.B., and Guo, J., 2013, Data report: Clay mineral assemblages in the Shikoku Basin, NanTroSEIZE subduction inputs, IODP Sites C0011 and C0012, in Saito, S., Underwood, M.B., Kubo, Y., and the Expedition 322 Scientists, Proceedings of the Integrated Ocean Drilling Program, Volume 322: Tokyo, Integrated Ocean Drilling Program Management International, Inc., 34 p., doi:10.2204/iodp.proc.322.202.2013.

Underwood, M.B., and Guo, J., 2017, Data report: Clay mineral assemblages in the upper Shikoku Basin, results from IODP Expedition 333, Sites C0011 and C0012, in Henry, P., et al., Proceedings of the Integrated Ocean Drilling Program, Volume 333: Tokyo, Integrated Ocean Drilling Program Management International, Inc. 13 p., doi:10.2204/iodp .proc.333.205.2017.

Underwood, M.B., and Pickering, K.T., 1996, Clay-mineral provenance, sediment dispersal patterns, and mudrock diagenesis in the Nankai accretionary prism, southwest Japan: Clays and Clay Minerals, v. 44, p. 339-356, doi:10.1346/CCMN.1996.0440304.

Underwood, M.B., Laughland, M.M., Byrne, T., Hibbard, J.P., and DiTullio, L., 1992, Thermal evolution of the Tertiary Shimanto belt, Muroto Peninsula, Shikoku, Japan: The Island Arc, v. 1, p. 116-132.

Underwood, M.B., Orr, R., Pickering, K., and Taira, A., 1993a, Provenance and dispersal patterns of sediments in the turbidite wedge of Nankai Trough, in Hill, I.A., Taira, A., Firth, J.V., et al., Proceedings of the Ocean Drilling Program, Scientific Results, Volume 131: College Station, Texas, Ocean Drilling Program, p. 15-34.

Underwood, M.B., Pickering, K., Gieskes, J.M., Kastner, M., and Orr, R., 1993b, Sediment geochemistry, clay mineralogy, and diagenesis: A synthesis of data from Leg 131, Nankai Trough, in Hill, I.A., Taira, A., Firth, J.V., et al., Proceedings of the Ocean Drilling Program, Scientific Results, Volume 131: College Station, Texas, Ocean Drilling Program, p. 343-363.

Underwood, M.B., Basu, N., Steurer, J., and Udas, S., 2003a, Data report: Normalization factors for semiquantitative $\mathrm{X}$-ray diffraction analysis, with application to DSDP Site 297, Shikoku Basin, in Mikada, H., Moore, G.F., Taira, A., Becker, K., Moore, J.C., and Klaus, A., et al., Proceedings of the Ocean Drilling Program, Scientific Results, Volume 190/196: College Station, Texas, Ocean Drilling Program, p. 1-28.

Underwood, M.B., Moore, G.F., Taira, A., Klaus, A., Wilson, M.E.J., Fergusson, C.L., Hirono, S., Steurer, J., and the Leg 190 Shipboard Scientific Party, 2003b, Sedimentary and tectonic evolution of a trench-slope basin in the Nankai subduction zone of southwest Japan: Journal of Sedimentary Research, v. 73, p. 589-602, doi:10.1306/092002730589.

Underwood, M.B., Saito, S., Kubo, Y., and the Expedition 322 Scientists, 2010 , Expedition 322 summary, in Saito, S., Underwood, M.B., Kubo, Y., and the
Expedition 322 Scientists, Proceedings of the Integrated Ocean Drilling Program Volume 322: Tokyo, Japan, Integrated Ocean Drilling Program Management International, Inc., doi:10.2204/iodp.proc.322.101.2010.

Usman, M.O., Masago, H., Winkler, W., and Strasser, M., 2014, Mid-Quaternary decoupling of sediment routing in the Nankai forearc revealed by provenance analysis of turbiditic sands: International Journal of Earth Sciences, v. 103, p. 1141-1161.

Uto, K., and Tatsumi, Y., 1996, Quaternary volcanism of the Japanese Islands: The Island Arc, v. 5, p. 250-261.

Völker, D., Reichel, T., Wiedicke, M., and Heubeck, C., 2008, Turbidites deposited on southern central Chilean seamounts: Evidence for energetic turbidity currents: Marine Geology, v. 251, p. 15-31, doi:10.1016/j.margeo 2008.01.008.

von Hagke, C., Philippon, M., Avouac, J.P., and Gurnis, M., 2016, Origin and time evolution of subduction polarity reversal from plate kinematics of Southeast Asia: Geology, v. 44, p. 659-662, doi:10.1130/G37821.1.

Wallace, L.M., Ellis, S., Miyao, K., Miura, S., Beavan, J., and Goto, J., 2009, Enigmatic, highly active left-lateral shear zone in southwest Japan explained by aseismic ridge collision: Geology, v. 37, p. 143-146, doi:10 1130/G25221A.1.

Wang, J., Li, A., Xu, K., Zheng, X., and Huang, J., 2015, Clay mineral and grain size studies of sediment provenances and paleoenvironmental evolution in the middle Okinawa Trough since 17 ka: Marine Geology, v. 366, p. 49-61, doi:10.1016/j.margeo.2015.04.007.

Wang, K., Hyndman, R.D., and Yamano, M., 1995, Thermal regime of the southwest Japan subduction zone: Effects of age history of the subducting plate: Tectonophysics, v. 248, p. 53-69, doi:10.1016/0040-1951(95)00028-L.

Wangen, M., 2001, A quantitative comparison of some mechanisms generating overpressure in sedimentary basins: Tectonophysics, v. 334, p. 211-234, doi:10.1016/S0040-1951(01)00064-6.

Watts, A.B., and Weissel, J.K., 1975, Tectonic history of the Shikoku marginal basin: Earth and Planetary Science Letters, v. 25, p. 239-250, doi:10 .1016/0012-821X(75)90238-1.

White, S.M., Chamley, H., Klein, G. deV., and Mizuno, A., 1980, Sediment synthesis: Deep Sea Drilling Project Leg 58, Philippine Sea, in Klein, G.deV., Kobayashi, K., et al., Initial Reports of the Deep Sea Drilling Project, Volume 58: Washington, D.C., U.S. Government Printing Office, p. $963-1013$.

Wu, J., Suppe, J., Lu, R., and Kanda, R., 2016, Philippine Sea and East Asian plate tectonics since $52 \mathrm{Ma}$ constrained by new subducted slab reconstruction methods: Journal of Geophysical Research-Solid Earth, v. 121, p. 4670-4741, doi:10.1002/2016JB012923.

Wu, S., Takahashi, N., Tokuyama, H., and Wong, H.K., 2005, Geomorphology, sedimentary processes and development of the Zenisu deep-sea channel, northern Philippine Sea: Geo-Marine Letters, v. 25, p. 230-240.

Wu, Z.Y., Li, J.B., Jin, X.L., Shang, J.H., Li, S.J., and Jin, X.B., 2014, Distribution, features, and influence factors of the submarine topographic boundaries of the Okinawa Trough: Science China: Earth Science, v. 57, p. $1885-1896$

Xu, Z., Li, T., Chang, F., Wan, S., Choi, J., and Lim, D., 2014, Clay-sized sediment provenance change in the northern Okinawa Trough since $22 \mathrm{kyr}$ $\mathrm{BP}$ and its paleoenvironmental implication: Palaeogeography, Palaeoclimatology, Palaeoecology, v. 399, p. 236-245, doi:10.1016/j.palaeo .2014.01.016.

Yamada, K., and Tagami, T., 2008, Postcollisional exhumation history of the Tanzawa tonalite complex, inferred from (U-Th)/He thermochronology and fission track analysis: Journal of Geophysical Research, v. 113, B03402, doi:10.1029/2007JB005368.

Yamaji, A., Sakai, T., Arai, K., and Okamura, Y., 2003, Unstable forearc stress in the eastern Nankai subduction zone for the last 2 million years: Tectonophysics, v. 369, p. 103-120, doi:10.1016/S0040-1951(03)00212-9.

Yamamoto, S., Nakajima, J., Hasegawa, A., and Maruyama, S., 2009, Izu-Bonin arc subduction under the Honshu Island, Japan: Evidence from geological and seismological aspect: Gondwana Research, v. 16, p. 572-580, doi:10.1016/j.gr.2009.05.014.

Yamamoto, T., and Hoang, N., 2009, Synchronous Japan Sea opening Miocene fore-arc volcanism in the Abukuma Mountains, NE Japan: An advancing hot asthenosphere flow versus Pacific slab melting: Lithos, v. 112, p. $575-590$.

Yamamoto, Y., and Kawakami, S., 2005, Rapid tectonics of the late Miocene Boso accretionary prism related to the Izu-Bonin arc collision: The Island Arc, v. 14, p. 178-198, doi:10.1111/j.1440-1738.2005.00463.x. 
Yamano, M., Kinoshita, M., Goto, S., and Matsubayashi, O., 2003, Extremely high heat flow anomaly in the middle part of the Nankai Trough: Physics and Chemistry of the Earth, v. 28, p. 487-497, doi:10.1016/S1474 -7065(03)00068-8

Yamashita, M., Tsuru, T., Takahashi, N., Takizawa, K., Kaneda, Y., Fujioka, K., and Koda, K., 2007, Fault configuration produced by initial rifting in the Parece Vela Basin as deduced from seismic reflection data: The Island Arc, v. 16, p. 338-347, doi:10.1111/j.1440-1738.2007.00594.x.

Yang, F.L., Xu, X., Zhao, W.F., and Sun, Z., 2011, Petroleum accumulations and inversion structures in the Xihu depression, East China Sea Basin: Journal of Petroleum Geology, v. 34, p. 429-440.

Yang, S., Hu, S., Cai, D., Feng, X., Chen, L., and Gao, L., 2004, Present-day heat flow, thermal history and tectonic subsidence of the East China Sea Basin: Marine and Petroleum Geology, v. 21, p. 1095-1105, doi:10.1016/j .marpetgeo.2004.05.007.

Yardley, G.S., and Swarbrick, R.E., 2000, Lateral transfer: Source of additional overpressure?: Marine and Petroleum Geology, v. 17, p. 523-537, doi:10.1016/S0264-8172(00)00007-6.

Yoshikawa, S., and Nemoto, K., 2010, Seasonal variations of sediment transport to a canyon and coastal erosion along the Shimizu coast, Suruga Bay, Japan: Marine Geology, v. 271, p. 165-176, doi:10.1016/j.margeo .2010 .02 .010 .

Yoshikawa, S., Satoguchi, Y., and Nagahashi, Y., 1996, A widespread volcanic ash bed in the horizon close to the Pliocene-Pleistocene boundary: Fukuda-Tsujimatagawa-Kd38 volcanic ash bed occurring in central
Japan: Journal of the Geological Society of Japan, v. 102, p. 258-270, doi:10.5575/geosoc.102.258.

Yoshioka, S., and Murakami, K., 2007, Temperature distribution of the upper surface of the subducted Philippine Sea plate along the Nankai Trough, southwest Japan, from a three-dimensional subduction model: Relation to large interplate and low-frequency earthquakes: Geophysical Journal International, v. 171, p. 302-315, doi:10.1111/j.1365-246X.2007.03510.x. Zang, S.X., Chen, Q.Y., Ning, J.Y., Shen, Z.K., and Liu, Y.G., 2002, Motion of the Philippine Sea plate consistent with the NUVEL-1A model: Geophysical Journal International, v. 150, p. 809-819, doi:10.1046/j.1365 $-246 X .2002 .01744 . x$

Zhao, D., 2012, Tomography and dynamics of western Pacific subduction zones: Monographs on Environment, Earth, and Planets, v. 1, p. 1-70, doi:10.5047/meep.2012.00101.0001.

Zhao, D., Yanada, T., Hasegawa, A., Umino, N., and Wei, W., 2012, Imaging the subducting slabs and mantle upwelling under the Japan Islands: Geophysical Journal International, v. 190, p. 816-828, doi:10.1111/j.1365 $-246 X .2012 .05550 . x$.

Zhao, Y., Liu, B., Li, X., Liu, C., Wu, J., and Wang, K., 2008, Submarine canyons on the north of Chiwei Island influenced by recent extension of the southern Okinawa Trough: Acta Oceanologica Sinica, v. 27, p. 63-72.

Manuscript Accepted by the Society 25 SePtember 2017

Manuscript Published Online Xx Month 2018 